УДК 582.394:581.4

\title{
Preliminary checklist of Hoya (Asclepiadaceae) in the flora of Cambodia, Laos and Vietnam
}

\author{
L. V. Averyanov ${ }^{1}$, Van The Pham², T. V. Maisak ${ }^{1}$, Tuan Anh Le ${ }^{3}$, Van Canh Nguyen ${ }^{4}$, Hoang Tuan \\ Nguyen $^{5}$, Phi Tam Nguyen ${ }^{6}$, Khang Sinh Nguyen ${ }^{2}$, Vu Khoi Nguyen ${ }^{7}$, Tien Hiep Nguyen ${ }^{8}$, M. Rodda ${ }^{9}$ \\ ${ }^{1}$ Komarov Botanical Institute, Prof. Popov, 2; St. Petersburg, RF-197376, Russia \\ E-mails:av_leonid@mail.ru; av_leonid@yahoo.com \\ ${ }^{2}$ Institute of Ecology and Biological Resources, Vietnam Academy of Sciences and Technology, 18 Hoang Quoc Viet, \\ Cau Giay, Ha Noi, Vietnam. E-mail: phamvthe@gmail.com \\ ${ }^{3}$ Quang Tri Center of Science and Technology, Mientrung Institute for Scientific Research, 121 Ly Thuong Kiet, Dong Ha, \\ Quang Tri, Vietnam.E-mail: tasa207@gmail.com \\ ${ }^{4}$ 3/12/3 Vo Van Kiet Street, Buon Ma Thuot City, Dak Lak province, Vietnam. E-mail: nguyenvancanh@gmail.com \\ ${ }^{5}$ Department of Pharmacognosy, Hanoi University of Pharmacy, 15 Le Thanh Tong, Hoan Kiem, Hanoi, Vietnam \\ E-mail: tuandl50@yahoo.com
}

${ }^{6}$ Viet Nam Post and Telecommunications Group - VNPT, Lam Dong 8 Tran Phu Street, Da Lat City, Lam Dong Province, Vietnam.E-mail: phitam77@gmail.com

${ }^{7}$ Wildlife At Risk, 202/10 Nguyen Xi st., ward 26, Binh Thanh, Ho Chi Minh, Vietnam.E-mail: nvkhoi70@gmail.com

${ }^{8}$ Center for Plant Conservation, no. 25/32, lane 191, Lac Long Quan, Nghia Do, Cau Giay District, Ha Noi, Vietnam E-mail: hiep.nguyen@cpcvn.org

${ }^{9}$ Herbarium, Singapore Botanic Gardens, 1 Cluny Road, Singapore 259569.E-mail: rodda.michele@gmail.com

Key words: Asclepiadaceae, Cambodia, eastern Indochina, endemism, flora, Hoya, Laos, plant diversity, plant taxonomy, Vietnam.

Summary. This paper provides new data on 33 new or rare species of Hoya obtained in fieldwork mainly during 2012-2017 in eastern Indochina including Cambodia, Laos and Vietnam. These data include illustrated descriptions of three species new for science, as well as illustrated records of 24 species new for the floras of the studied countries. When these new data are included, the flora of eastern Indochina comprises at least 45 species. Among them eight species are recorded and documented for Cambodia, $21 \mathrm{sp}$. for Laos and $40 \mathrm{sp}$. for Vietnam; two new species are described in Vietnam (H. crassipetiolata and H. nutans) and one species is described from Laos (H. uniflora). Eighteen species were recorded newly for the flora of Vietnam (H. arnottiana, H. burmanica, H. chinghungensis, H. erythrina, H. erythrostemma, H. fungii, H. griffithii, H. hainanensis, H. lanceolata, H. linearis, H. loyceandrewsiana, H. mengtzeensis, $H$. nummularioides, $H$. pachyclada, $H$. pandurata, $H$. parviflora, $H$. revolubilis, $H$. vaccinioides), nine for Laos (H. arnottiana, H. carnosa, H. chinghungensis, H. fungii, H. globulosa, H. griffithii, H. linearis, $H$. pandurata, $H$. polyneura) and two for Cambodia (H. lobbii, H. multiflora). New localities were discovered for H. bonii, H. lockii, H. lyi, H. micrantha, H. multiflora, H. oblongacutifolia, and $H$. verticillata known earlier in Cambodia, Laos and Vietnam by few collections. Lectotypes are proposed for the following eight species: H. arnottiana, $H$ griffithii, $H$. lanceolata, H. lobbii, H. nummularioides, $H$. oblongacutifolia, $H$. pachyclada, and $H$. vaccinioides. Names of five taxa earlier known as separate species (H. villosa, $H$. pseudovalifolia, $H$. graveolens, $H$. balansae) are regarded as synonyms of $H$. globulosa, $H$. micrantha, $H$. oblongacutifolia, $H$. verticillata respectively. 


\title{
Предварительный список видов Ноуа (Asclepiadaceae) во флоре Камбоджи, Лаоса и Вьетнама
}

\author{
Л. В. Аверьянов ${ }^{1}$, Ван Те Фам², Т. В. Майсак ${ }^{1}$ Туан Ань Ле \\ Фи Там Нгуен ${ }^{6}$, Кхань Синь Нгуен ${ }^{2}$, Ву Кхой Нгуен ${ }^{7}$, Тьен Хьеп Нгуен ${ }^{8}$, М. Родда ${ }^{9}$
}

${ }^{\prime}$ Ботанический институт им. В. Л. Комарова РАН, ул. Проф. Попова, 2; Санкт-Петербург, 197376, Россия

${ }^{2}$ Институт экологи и биологических ресурсов, Академии наук и технологии Вьетнама, 18 Хоанг Куок Вьет, Кай Зяу, Ханой, Вьетнам

${ }^{3}$ Научно-технологический Центр Куанг Чи, Миентрунг Институт Научных Исследований, 121, Ли Туонг Кьет, Донг Ха, Куанг Чи, Вьетнам

${ }^{4}$ 3/12/3 Во Ван Кьет, Банметуот, повинция Даклак, Вьетнам

\author{
${ }_{5}^{5}$ Отдел Фармакогнозии, Университет Фармакологии г. Ханоя, 15 Ле Тханг Тонг, Хоан Кием, Ханой, Вьетнам \\ 6 “Почта и Телекоммуникации Вьетнама - ВНПТ”, Лам Донг 8 Чан Фу, Далат, провинция Лам Донг, Вьетнам \\ 7 “Дикая Природа в Опасности”, 202/10 Нгуен Си, Вард 26, Бинь Тханх, Хо Ши Мин, Вьетнам \\ ${ }^{8}$ Центр охраны растений, № 25/32, линия 191, Лак Лонг Куан, Ни До, Кай Гау, Ханой, Вьетнам \\ ${ }^{9}$ Ботанический сад Сингапура, 1 Клани Роад, Сингапур, 259569
}

Ключевые слова: восточный Индокитай, Вьетнам, Камбоджа, Лаос, разнообразие растений, таксономия растений, флора, эндемизм, Asclepiadaceae, Hoya.

Аннотация. Статья содержит сведения о 33 новых и редких видах рода Ноуа, полученные в ходе полевых работ, проводившихся на протяжении 2012-2017 гг. в восточном Индокитае, включающем территорию Камбоджи, Лаоса и Вьетнама. Полученные результаты включают иллюстрированные описания 3 видов, новых для науки, а также 24 видов, новых для флор изучаемых стран. С учетом этих данных флора восточного Индокитая насчитывает как минимум 45 видов рода, произрастание восьми из которых задокументировано для Камбоджи, 21 - для Лаоса и 40 - для Вьетнама. Два новых для науки вида описаны из Вьетнама (H. crassipetiolata и $H$. nutans) и один - из Лаоса (H. uniflora). 18 видов впервые указываются для флоры Вьетнама (H. arnottiana, $H$. burmanica, H. chinghungensis, H. erythrina, H. erythrostemma, H. fungii, H. griffithii, H. hainanensis, $H$. lanceolata, $H$. linearis, $H$. loyceandrewsiana, H. mengtzeensis, $H$. nummularioides, $H$. pachyclada, H. pandurata, H. parviflora, H. revolubilis, H. vaccinioides), 9 - для флоры Лаоса (H. arnottiana, H. carnosa, H. chinghungensis, H. fungii, H. globulosa, H. griffithii, H. linearis, H. pandurata, H. polyneura) и 2 - для флоры Камбоджи (H. lobbii, H. multiflora). Выявлены новые местонахождения ряда редких видов (H. bonii, H. lockii, H. lyi, H. micrantha, H. multiflora, H. oblongacutifolia и H. verticillata), известных ранее в восточном Индокитае по единичным сборам. Для 8 видов (H. arnottiana, Hgriffithii, H. lanceolata, H. lobbii, H. nummularioides, H. oblongacutifolia, H. pachyclada и H. vaccinioides) выбраны лектотипы. Названия 5 таксонов, принимаемых ранее в качестве самостоятельных видов (H. villosa, H. pseudovalifolia, H. graveolens, H. balansae), сведены в синонимы к следующим принятым ныне видам: H. globulosa, H. micrantha, H. oblongacutifolia, H. verticillata, соответственно.

\section{Introduction}

The genus Hoya R. Br. (Brown, 1810) includes $350-450$ currently accepted species found throughout tropical Asia, tropical Pacific islands and NE Australia (Li et al., 1995; Forster, Liddle, 1996; Forster, 2006; Liddle, 2009; Rodda, 2015). Mainland southeast Asia and particularly the Indochinese Peninsula should be presently recognized as one of the richest areas of the genus species diversity with 41 species recorded up to now in Thailand (Thaithong, 2001; Kidyoo, Thaithong, 2007a, b), 32 species in southern China ( $\mathrm{Li}$ et al., 1995), 26 species in Vietnam (Costantin, 1912; Pham, 2003; Tran, 2005;
Tran et al., 2011a, b; Pham, Averyanov, 2012; The, Averyanov, 2012; Rodda et al., 2012, 2015; Rodda, Simonsson Juhonewe, 2013; Pham et al., 2015), 19 species in Myanmar (Kress et al., 2003), 10 species in Lao PDR (Newman et al., 2007, Rodda, 2012; Rodda et al., 2015) and five species in Cambodia (Costantin, 1912). Meanwhile, countries of eastern Indochina including Cambodia, Laos and Vietnam certainly rich in Hoya species remain up to the present study insufficiently studied. This paper provides illustrated description of three species new for science (H. crassipetiolata, $H$. nutans, $H$. uniflora), as well as illustrated records of 24 species 
new for the floras of Cambodia, Laos and Vietnam. When these new data are included, flora of eastern Indochina including Cambodia, Laos and Vietnam encompasses at least 45 species (Table 1). Among them, eight species are recorded and documented for Cambodia, $21 \mathrm{sp}$. for Laos and $40 \mathrm{sp}$. for Vietnam; two new species are described from Vietnam (H. crassipetiolata and $H$. nutans) and one from Laos (H. uniflora). Eighteen species are newly recorded for the flora of Vietnam (H. arnottiana, H. burmanica, $H$. chinghungensis, H. erythrina, H. erythrostemma, $H$. fungii, $H$. griffithii, $H$. hainanensis, $H$. lanceolasis, $H$. nummularioides, $H$. pachyclada, $H$. pandurata, $H$. parviflora, $H$. revolubilis, $H$. vaccinioides), nine for Laos (H. arnottiana, H. carnosa, H. chinta, $H$. linearis, $H$. loyceandrewsiana, $H$. mengtzeen-

ghungensis, H. fungii, H. globulosa, H. griffithii, H. pandurata, $H$. polyneura), and two for Cambodia (H. lobbii, H. multiflora). New localities are discovered for H. bonii, H. lockii, H. lyi, H. micrantha, H. multiflora, $H$. oblongacutifolia and $H$. verticillata previously known in Cambodia, Laos and Vietnam based on few collections. Lectotypes are proposed for nine species. These species are $H$. arnottiana, $H$. globulosa, $H$ griffithii, $H$. lanceolata, $H$. lobbii, $H$. nummularioides, $H$. oblongacutifolia, $H$. pachyclada, and $H$. vaccinioides. Names of five taxa previously accepted as distinct species (H. villosa, $H$. pseudovalifolia, $H$. graveolens, $H$. balansae) are regarded as synonyms of H. globulosa, H. micrantha, H. oblongacutifolia, H. verticillata respectively.

Table 1

\section{Species of Hoya R. Br. reported in the flora of Cambodia, Laos and Vietnam}

(Costantin, 1912; Tran, 2005; Pham, 2003; Tran et al., 2011b; Pham, Averyanov, 2012; Rodda, 2012; Rodda, Simonsson Juhonewe, 2012a, b; 2013; Rodda et al., 2012, 2013, 2015; Pham, Averyanov 2012; Pham et al., 2015).

\begin{tabular}{|c|c|}
\hline Hoya arnottiana Wight $\left[\mathrm{L}^{* *}, \mathrm{~V}^{* *}\right]$ & H. longipedunculata V. T. Pham et Aver. [V] \\
\hline H. bonii Costantin $\left[\mathrm{V}^{*}\right]$ & H. loyceandrewsiana T. Green [ $\left.\mathrm{V}^{* *}\right]$ \\
\hline H. burmanica Rolfe [ $\left.\mathrm{V}^{* *}\right]$, & H. lyi H. Lév. [V*] \\
\hline H. $\operatorname{carnosa}$ (L. f.) R. Br. [L**] & H. mengtzeensis Tsiang et $\mathrm{P} . \mathrm{T}$. $\mathrm{Li}\left[\mathrm{V}^{* *}\right]$ \\
\hline H. chinghungensis (Tsiang et P. T. Li) M. G. Gilbert, P. & H. micrantha Hook. f. $\left[\mathrm{C}^{*}, \mathrm{~L}^{*}, \mathrm{~V}^{*}\right]$ \\
\hline T. Li et W. D. Stevens [L**, V**] & H. minima Costantin [V] \\
\hline H. crassipetiolata Aver., V. T. Pham et T. A. Le [V***] & H. multiflora Blume $\left[\mathrm{C}^{* *}, \mathrm{~L}^{*}, \mathrm{~V}^{*}\right]$ \\
\hline H. diversifolia Blume $[\mathrm{C}, \mathrm{L}, \mathrm{V}]$ & H. nummularia Hook. f. [V] \\
\hline H. erythrina Rintz [ $\left.\mathrm{V}^{* *}\right]$ & H. nummularioides Costantin [C, L, $\left.\mathrm{V}^{* *}\right]$ \\
\hline H. erythrostemma Kerr [ $\left.\mathrm{V}^{* *}\right]$ & H. nutans V. T. Pham et Aver. [V***] \\
\hline H. chinghungensis (Tsiang et P. T. Li) M. G.Gilbert et & H. oblongacutifolia Costantin [ $\left.\mathrm{V}^{*}\right]$ \\
\hline al. $[\mathrm{L} * *, \mathrm{~V} * *]$ & H. pachyclada Kerr $\left[\mathrm{C}, \mathrm{L}, \mathrm{V}^{* *}\right]$ \\
\hline H. fungii Merr. [ $\left.\mathrm{L}^{* *}, \mathrm{~V}^{* *}\right]$ & H. pandurata Tsiang [L**, $\left.\mathrm{V}^{* *}\right]$ \\
\hline H. fusca Wall. [C, L, V] & H. parviflora Wight $\left[\mathrm{V}^{* *}\right]$ \\
\hline H. globulosa Hook. f. [L**, V] & H. polyneura Hook. f. [L**] \\
\hline H. griffithii Hook. f. [L**, $\left.\mathrm{V}^{* *}\right]$ & H. revolubilis Tsiang et $\mathrm{P} . \mathrm{T} . \mathrm{Li}\left[\mathrm{V}^{* *}\right]$ \\
\hline H. hainanensis Merr. $\left[\mathrm{V}^{* *}\right]$ & H. sapaensis T. B. Tran et Rodda [V] \\
\hline H. hanhiae V. T. Pham et Aver. [V] & H. tamdaoensis Rodda et T. B. Tran [V] \\
\hline H. ignorata T. B. Tran et al. [V] & H. thuathienhuensis T. B. Tran et al. [V] \\
\hline H. kerrii Craib $[\mathrm{L}, \mathrm{V}]$ & H. uniflora Aver. et V. T. Pham [L***] \\
\hline H. lanceolata D. Don $\left[\mathrm{V}^{* *}\right]$ & H. vaccinioides Hook. f. [L, $\left.\mathrm{V}^{* *}\right]$ \\
\hline H. linearis Wall. ex D. Don [L**, $\left.\mathrm{V}^{* *}\right]$ & H. vangviengiensis Rodda et Simonsson [L] \\
\hline H. lobbii Hook. f. [C**] & H. verticillata (Vahl.) G. Don $\left[\mathrm{C}^{*}, \mathrm{~L}, \mathrm{~V}^{*}\right]$ \\
\hline
\end{tabular}

\author{
H. longipedunculata V. T. Pham et Aver. [V] \\ H. lyi H. Lév. [V*] \\ H. mengtzeensis Tsiang et P. T. Li [ $\left.\mathrm{V}^{* *}\right]$ \\ H. micrantha Hook. f. [C*, L*, V*] \\ minima Costantin [V] \\ multiflora Blume [C**, \\ H. nutans V. T. Pham et Aver. [V***] \\ H. oblongacutifolia Costantin $\left[\mathrm{V}^{*}\right]$ \\ H. pachyclada Kerr [C, L, $\mathrm{V}^{* *}$ ] \\ H. pandurata Tsiang [L**, $\left.\mathrm{V}^{* *}\right]$ \\ H. parviflora Wight [ $\left.\mathrm{V}^{* *}\right]$ \\ H. polyneura Hook. f. [L**] \\ H. revolubilis Tsiang et $\mathrm{P}$. T. $\mathrm{Li}\left[\mathrm{V}^{* *}\right.$ ] \\ H. sapaensis T. B. Tran et Rodda [V] \\ H. tamdaoensis Rodda et T. B. Tran [V] \\ H. vaccinioides Hook. $\mathrm{f}$. [L, $\left.\mathrm{V}^{* *}\right]$ \\ H. verticillata (Vahl.) G. Don $\left[\mathrm{C}^{*}, \mathrm{~L}, \mathrm{~V}^{*}\right]$
}

Legend for the table. The occurrence of each species in Cambodia, Laos and Vietnam is designated by letters " $\mathrm{C}$ ", "L" and "V" respectively (placed in square brackets after the name), rediscoveries for these countries are marked by one asterisk "*"; new records for countries respectively are marked by double asterisk "**”, species described as new for science are marked with triple asterisk "***", names of rare and critical species recorded in this paper are displayed in bold font. The following species have also been recorded for Vietnam, but are erroneous: Hoya wallichiana Decne (Decaisne, 1844), H. wallichii (Wight) C. M. Burton (Wight, 1834; Burton, 1996; Rodda et al., 2016), H. macrophylla Blume (Blume, 1826); H. cochinchinensis (Lour.) Schult. (Loureiro, 1790; Schultes, 1820), has been identified as an earlier name for H. verticillata (Vahl) G. Don (Vahl, 1810; Don, 1838) and has been proposed for rejection (Rodda, 2016); H. reticulata Costantin (Costantin, 1912) is a nom. illeg., non Hoya reticulata Moon (Moon, 1824) and is conspecific with H. multiflora (Blume, 1823); H. pseudolanceolata Costantin (Costantin, 1912) is based on fruiting material that appears to belong to Aeschynanthus sp. 


\section{Materials and methods}

Materials suitable for studies were field collected mainly during 2012-2017. Herbarium studies at IBSC, P and SING and some previously gathered herbarium specimens and living collections provided significant additional information for the current investigation. Fresh inflorescences and flowers were fixed and preserved in 60-70\% ethanol. Measurements of floral parts for descriptions were made on both living and liquid-preserved materials. Fresh flowers or floral parts were found to shrink up to ca $15-25 \%$ in size in the drying process of making herbarium specimens. It is noteworthy that floral parts of Hoya species shrink often disproportionally, in particular the corona contracts less than sepals and petals. This was taken into account when dried herbarium specimens were studied. In describing quantitative characters, infrequent extreme values (i.e. rarely occurring minimal and maximal values) of a variation range are parenthesized respectively before and after a normal variation range.

The annotated list of all discovered species is presented below. Paragraphs for species are arranged in the list according to species name in alphabetic order. The annotation for each species includes following data in separate lines:

- valid name and main synonyms, occurring in regional literature;

- data about type or original materials;

- living form, summarized available data on ecology, habitat elevation, phenology and observed rarity;

- distribution in studied countries (mostly by listing of the country provinces) and general distribution;

- short notes on taxonomy, expected relations and/or biology;

- abbreviated and unified text of herbarium labels including geographical locality, collection date, collectors' names, collection number and acronym of herbarium where mentioned specimen is housed.

Color and line illustrations of voucher specimens are provided for almost all recorded species. Species distribution in countries of eastern Indochina is indicated in the text by mentioning concerned provinces according to the current official administrative division. Online version of the IUCN Red List of Threatened Species (2016) was used for estimation of preliminary species conservation status.
Annotated list of new, rare and critical Hoya species in the flora of Cambodia, Laos and Vietnam

Hoya arnottiana Wight,

1834, Contr. Bot. India: 37.

Fig. 1.

Described (Wight, 1834) from Nepal ("In Nepal"). Lectotype ("Wallich, Asclep. no. 35. Herbarium Robert Wight Proper") - K [K000873110!], isolectotype - E [E00179574!]; lectotype here designated.

Noltie (2005) indicated type of $H$. arnottiana 'Nepal' (Sillet), Wallich, Wall. Asclep. 35 [= Wall. Cat. 8161] (E!, K!). A specimen labelled HRWP (Herbarium Robert Wight Proper) and annotated "35. Hoya arnottiana RW Nepal" is present at K and is here selected as lectotype.

Vernacular name in Vietnam. Cẩm cù chẻ.

Description. Epiphytic and lithophytic vine with milky latex 2-4 m long. Stem dull pale greenishgrey, young brown-grey hairy, old glabrous, slender, weak, terete, $2.5-3 \mathrm{~mm}$ in diam., twining or climbing by adventitious roots; internodes $5-20 \mathrm{~cm}$ long. Leaves petiolate, decussate. Petiole brown-grey hairy, thick, terete, dark green, curved, often upward, $1.7-2 \mathrm{~cm}$ long, $2.5-3 \mathrm{~mm}$ in diam. Leaf blade rather fleshy, elliptic, $8.5-10.5 \mathrm{~cm}$ long, $3.5-6 \mathrm{~cm}$ wide, cuneate or round at base, acuminate and curved at apex, adaxially glabrous, dark green, glossy, margin often slightly incurved, net-veined, lateral veins in 4-5 pairs; abaxial surface whitish-green, pubescent with brown-grey hairs, prominent midrib and visible lateral veins. Inflorescence an extra-axillary manyflowered umbel, with up to 40 flowers, hemispheric; peduncle rather stout, straight, cylindrical, swollen at base and apex, brown-grey hairy, 3.5-7 cm long, $2.5-3 \mathrm{~mm}$ in diam. at narrower part, 5.5-5.8 $\mathrm{mm}$ in diam. at thicker parts, light olive- greenish; pedicels white to light greenish, cylindrical, slender, 21.5-22.5 mm long, $0.8-1 \mathrm{~mm}$ in diam., glabrous. Flowers almost white. Calyx flat, $5.4-5.6 \mathrm{~mm}$ in diam., shortly, sparsely hairy, of 5 sepals joined at base, sepals yellowish-white, triangular narrowly ovate, acute, $1.8-2.2 \mathrm{~mm}$ long, $1.3-1.7 \mathrm{~mm}$ wide near base. Corolla of 5 petals, being flattened 1.65 $1.75 \mathrm{~cm}$ in diam., white; petals reflexed, margin and apex revolute, rhomboid, connate, $7.8-8.5 \mathrm{~mm}$ long, $4.8-5.3 \mathrm{~mm}$ wide, triangular acute at apex, outsides glabrous, inside shortly pubescent. Corona glossy, pure white, sometime with light pink tint in center, 


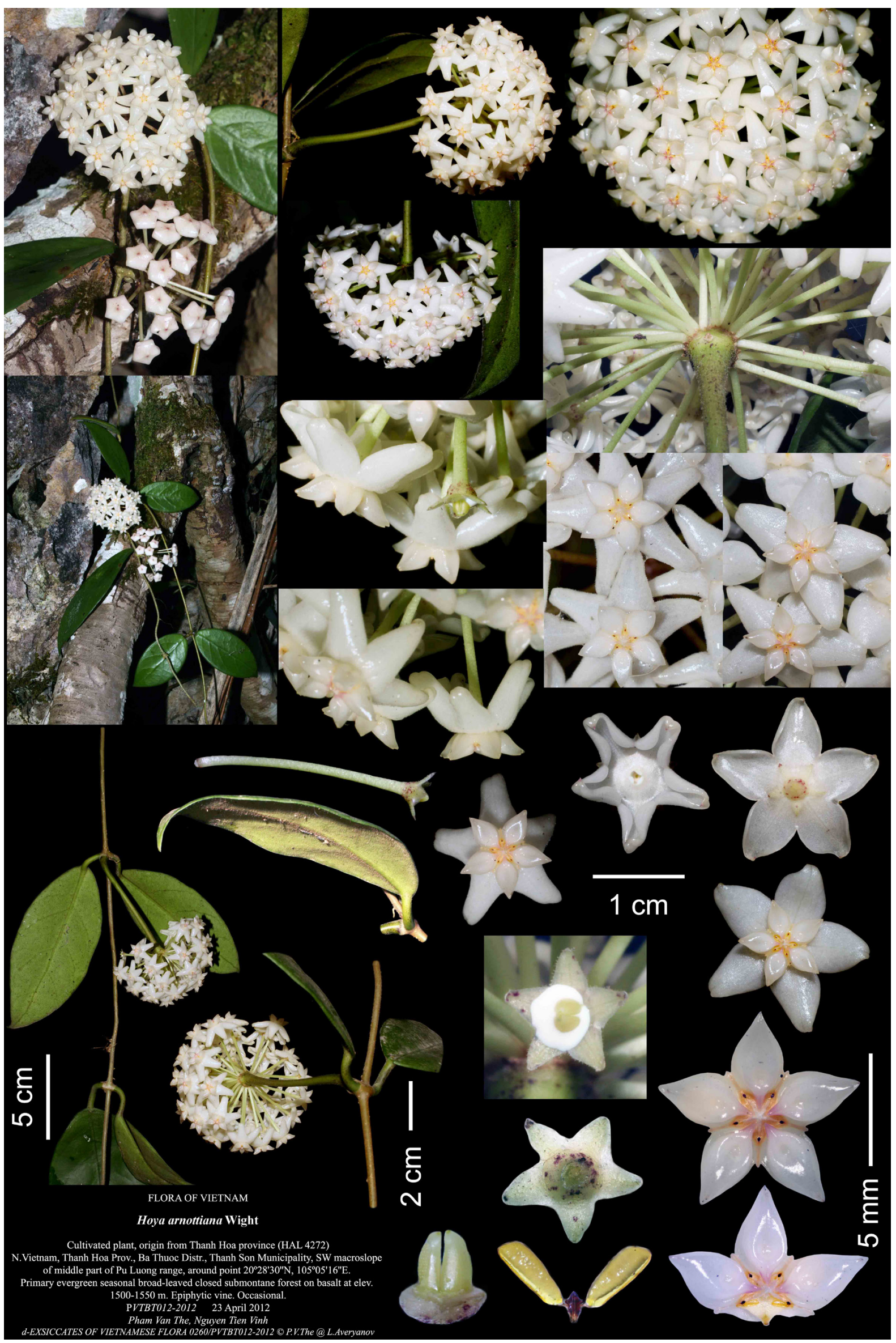

Fig. 1. Hoya arnottiana Wight. Digital Vietnamese flora 0260/PVT BT 012-2012. Photos by V. T. Pham, correction and design by L. Averyanov and T. Maisak. 
of 5 segments, $2 \mathrm{~mm}$ tall, 8.6-8.8(9) $\mathrm{mm}$ in diam., grooved between segments; segments obliquely ellipsoid in outline, little concave above, 4.3-4.8 $\mathrm{mm}$ long, 2.4-2.7 $\mathrm{mm}$ wide, outer angle acute, notched of bifid into two small unequal teeth, inner angles shortly acuminate, not reaching gynostegium apex. Gynostegium with 5 pollinaria covered by scarious, yellowish anther caps. Pollinarium with minute corpusculum, hardly visible translators and 2 pollinia; corpusculum narrowly rhomboid, angled, with two small wings beside, grooved, chestnut-brown, $0.10-0.11 \mathrm{~mm}$ long, 0.24-0.26 $\mathrm{mm}$ wide; translators very short, about $0.03 \mathrm{~mm}$ long; pollinia oblong, $0.6-0.7 \mathrm{~mm}$ long, $0.2-0.25$ $\mathrm{mm}$ wide, yellow; germinating crest very narrow, light yellowish, hyaline, extending from translator to pollinium apex. Ovary of 2 carpels, free, bottleshaped. Carpels half bottle-shaped, connivent each other, $1.4-1.5 \mathrm{~mm}$ tall, $0.5-0.7 \mathrm{~mm}$ in diam.

Habitat, phenology and conservation status. Epiphytic semi-woody vine about $3 \mathrm{~m}$ long. Primary evergreen seasonal broad-leaved closed submontane forest on basalt, 1500-1550 m. Fl. April - June. Not common. Estimated IUCN Red List status - DD.

Distribution. Laos (Houaphan province), Vietnam (Dak Lak and Thanh Hoa provinces). India, Thailand.

Notes. This new record for the floras of Laos and Vietnam considerably extends the distribution area of Hoya arnottiana that was so far only known from Nepal and India (Assam, Meghalaya, Sikkim and West Bengal). The species was also collected in northern Thailand (Chiang Mai), but without exact locality (M. Rodda MR 574, SING). The species is insufficiently known in Indochina, hence we provide here its full description based on personally studied Laotian and Vietnamese specimens.

Studied specimens. Northern Laos, Houphan province, Viengxay district, Xieng Luong village, around point $20^{\circ} 22^{\prime} 06.1^{\prime \prime} \mathrm{N}, 104^{\circ} 17^{\prime} 18.6^{\prime \prime} \mathrm{E}$, primary and secondary broad-leaved evergreen dry forest on limestone at $600-700 \mathrm{~m}$, semi-woody vine $2-3 \mathrm{~m}$ long on open mossy rocks, flowers entirely white, strong sweet fragrant, common, 8 April 2015, N. T. Hiep, L. Averyanov, N. S. Khang et al., LA-VN 1156 (FOF, HNL, LE - photos). Northern Laos, Houphan province, Vieng Thong district, Nam Et - Phou Louey Natural protected area, Tad Hokdon WF, disturbed primary forest, along stream, $802 \mathrm{~m}, 20^{\circ} 06^{\prime} 21.6^{\prime \prime} \mathrm{N}$, $103^{\circ} 22^{\prime} 15.2^{\prime \prime} \mathrm{E}, 7$ June 2013, J. Leong-Skornickova et al., JLS-2394 (E, Pha Tad Ke, P, QBG, SING). Northern Vietnam, Thanh Hoa province, Ba Thuoc district, Thanh Son municipality, SW macro-slope of middle part of $\mathrm{Pu}$ Luong range around point $20^{\circ} 28^{\prime} 30^{\prime \prime} \mathrm{N}, \quad 105^{\circ} 05^{\prime} 16^{\prime \prime} \mathrm{E}$, primary evergreen seasonal broad-leaved closed submontane forest on basalt at elev. 1500-1550 m, epiphytic vine, occasional, 10 October 2003, L. Averyanov et al., HAL 4272 (LE, LE - photos). Southern Vietnam, Dak Lak province, sine loc., N. V. Canh s. n., 2014 (LE - photos). Plate: digital Vietnamese flora 0260/ PVT BT 012-2012, fig. 1.

\section{Hoya bonii Costantin,}

1912, Fl. Indo-Chine 4: 140; Pham H. H., 2003, Ill. Fl. Vietnam 2: 747, fig. 6989; Tran T. B., 2005, Checklist Pl. Sp. Vietnam 3: 66.

Fig. 2.

Described from central Vietnam ("Vo Xa (?) Mountain"). Type ("Tonkin occidental, in introitu montium Vòxà, R. P. Bon 2703, 1884-6-19") - P [syntypes - P00645998, P00645999, P00646000].

Vernacular name in Vietnam. Cẩm cù bon.

Habitat, phenology and conservation status. Epiphytic and lithophytic vine to $5 \mathrm{~m}$ long with yellow latex. Secondary evergreen, broad-leaved, limestone forests close to the sea, 0-100 m. Fl. May. Locally very common. Estimated IUCN Red List status - VU.

Distribution. Vietnam (Hai Phong and Quang Ninh province). Endemic.

Notes. This is the first rediscovery of this species since more than 100 years from its description in 1884 when it was recorded without indication of exact locality of type collection. Although this species is locally common, it has restricted distribution in an area less than $150 \mathrm{~km}^{2}$. In corolla and corona morphology, the species is similar to $H$. fungii Merr. (Merrill, 1934) or H. carnosa (L. f.) R. Br. (Linne, 1782; Brown, 1810) but distinguishes in leaves cordate at the base (rarely round), hairy below and along margin. The variation of $H$. carnosa has not been studied in detail yet and it may be possible that further studies will bring to synonymise $H$. bonii with $H$. carnosa.

Studied specimens. Northern Vietnam, Hai Phong province, Cat Hai district, Viet Hai village, Cat Ba national park around point $20^{\circ} 46^{\prime} \mathrm{N}, 107^{\circ} 1^{\prime} \mathrm{E}$, 0-100 m, secondary limestone forest close to sea, epiphytic or lithophytic vine to $5 \mathrm{~m}$ long with yellow latex, leaves thick, variable in shape, leaf base cordate, apex acute, young peduncles and stems brown hairy, mature glabrous, umbels with 12 to 32 flowers, flowers white with pinkish-red corona, chocolate fragrant at night, open till midday, locally 


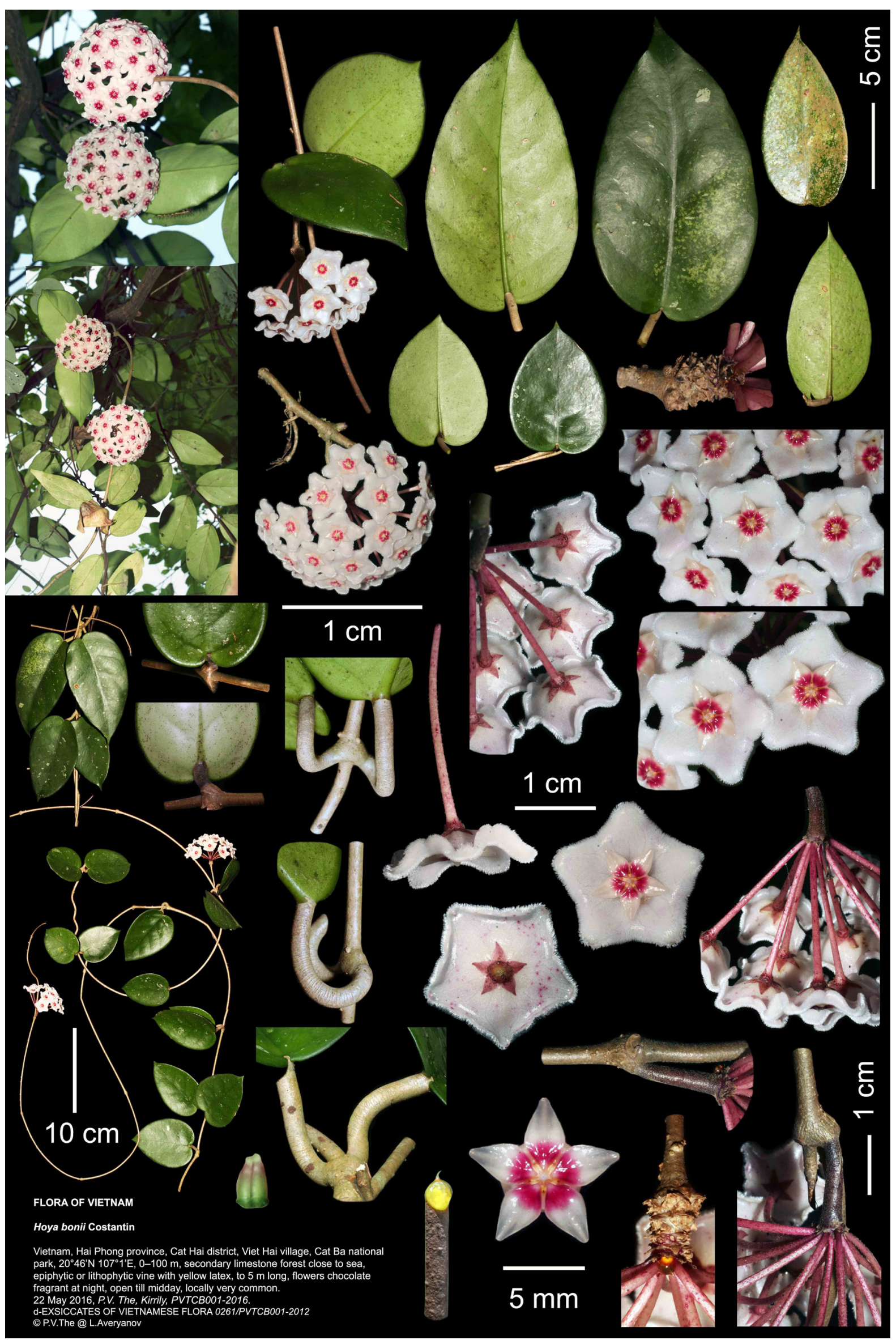

Fig. 2. Hoya bonii Costantin. Digital Vietnamese flora 0261/PVT CB 001-2012. Photos by V. T. Pham, correction and design by L. Averyanov and T. Maisak. 
very common, 22 May 2016, P. V. The, Kirrily, PVT CB 001-2016 (HN, LE). Plate: digital Vietnamese flora 0261/PVT CB 001-2012, fig. 2.

\section{Hoya burmanica Rolfe,}

1920, Bull. Misc. Inform. Kew 10: 343; Rodda, Simonsson Juhonewe, 2012 , Kew Bull. 67: 1.

Fig. 3A-C.

Described (Rolfe, 1920) from Myanmar ("Burma: Chin Hills"). Lectotype ("Cult. in Hort. Bot. Reg. Kew A. 191, Aug. 1920, s. n.") - K [K000449127], lectotype designated by Rodda and Simonsson Juhonewe (2012a).

Vernacular name in Vietnam. Cẩm cù burma.

Habitat, phenology and conservation status. Lithophytic and occasionally epiphytic undershrub with pendulous shoots to $1 \mathrm{~m}$ long. Primary evergreen broad-leaved humid forests on rocky limestone, commonly on shady cliffs at mountaintops, 13501500 m. Fl. April - August. Very rare. Estimated IUCN Red List status - EN.

Distribution. Vietnam (Dien Bien province). NE India, N Myanmar, N Thailand.

Notes. The discovery of $H$. burmanica in northwestern Vietnam considerably expands the known distribution area of this species to the east. It grows in Vietnam in humid evergreen forests, a rather different environment from the seasonally dry open woodlands where it can be found in Myanmar. In Natma Taung National Park (Myanmar) it is one of the most common epiphytes at $1500-1800 \mathrm{~m}$, but it was not found to grow as a lithophyte (M. Rodda, pers. obs.).

Studied specimens. Northern Vietnam, Dien Bien province, Tua Chua district, Sin Chai municipality, $22^{\circ} 03^{\prime} 38^{\prime \prime} \mathrm{N}, 103^{\circ} 19^{\prime} 56^{\prime \prime} \mathrm{E}$, primary humid evergreen broad-leaved forest on limestone at 1350 $1500 \mathrm{~m}$, lithophytic pendent undershrub on vertical shady mossy cliff on top of ridge, not common, 14 December 2010, L. Averyanov et al., CPC 948 (HN, LE). Northern Vietnam, Son La province, Moc Chau district, 2016, C. X. Canh, s. n. (LE - photo).

Hoya carnosa (L. f.) R. Br.,

1810, Prodr. Fl. Nov. Holland.: 460; Li et al., 1995, Fl. China 16: 232; Pham H.H., 2003, Ill. Fl. Vietnam 2: 747, fig. 6990; Tran T.B., 2005, Checklist Pl. Sp. Vietnam 3: 66.

$\equiv$ Asclepias carnosa L. f., 1782, Suppl. Pl.: 170; Sims, 1804, Bot. Mag. 21, tab. 788.

Described from China ("Habitat in China"). Type ("LINN 310.43") - LINN.

$=$ Stapelia chinensis Lour., 1790, Fl. Cochinchin.: 165.
Fig. 3D-F.

Vernacular name in Vietnam. Cẩm cù lý hương sao.

Habitat, phenology and conservation status. Semi-woody epiphytic creeping vine to $3 \mathrm{~m}$ long. Flowers white with pink-purple centre, very fragrant. Primary and secondary broad-leaved evergreen and semideciduous dry forests on any kind of rocks, but preferably on rocky limestone, often near mountaintops, 500-900 m. Fl. March April. Occasional. Estimated IUCN Red List status - LC.

Distribution. Laos (Houphan and Vientiane provinces), Vietnam (Hoa Binh, Quang Binh, Quang Ninh, Quang Tri, Lam Dong, Ba Ria - Vung Tau provinces). India, China, Taiwan, Japan.

Notes. This is the first record for Laos although the species is widely distributed in mainland tropical Asia.

Studied specimens. Northern Laos, Houphan province, Hem district, Khon Ngua village, $19^{\circ} 55^{\prime} 53.2^{\prime \prime} \mathrm{N}, 103^{\circ} 16^{\prime} 24.2^{\prime \prime} \mathrm{E}$, secondary broadleaved evergreen open dry forest with bamboo on limestone, 700-950 m, epiphytic and lithophytic creeping vine 2-3 m long on very steep rocky slope, flowers fragrant, white, with reddish disk, common, 15 April 2015, N. T. Hiep et al., LA-VN 1491 (FOF, LE - photo). Central Laos, Vientiane province, Vang Vieng district, Phol Xai village, about $8 \mathrm{~km}$ to the W of Vang Vieng town, Phar Poon Mt., around point $18^{\circ} 56^{\prime} 11.5^{\prime \prime} \mathrm{N}, 102^{\circ} 20^{\prime} 05.0^{\prime \prime} \mathrm{E}$, dry broadleaved primary and secondary evergreen forest on limestone, semi-woody epiphytic and lithophytic vine $4 \mathrm{~m}$ long at elevation $800-900 \mathrm{~m}$, flowers light yellowish to almost white, center pink-purple, no common, 15 March 2013, N. T. Hiep et al., LA-VN 439 (FOF, LE). Central Laos, Vientiane province, Vang Vieng district, Phol Xai village, about $8 \mathrm{~km}$ to the $\mathrm{W}$ of Vang Vieng town, Phar Poon Mt., around point $18^{\circ} 56^{\prime} 11.5^{\prime \prime} \mathrm{N}, 102^{\circ} 20^{\prime} 05.0^{\prime \prime} \mathrm{E}$, dry broadleaved primary and secondary evergreen forest limestone, semi-woody epiphytic vine $5 \mathrm{~m}$ long on rocky mountaintops at elevation $800-900 \mathrm{~m}$, very common, 15 March 2013, N. T. Hiep et al., LA-VN 458 (FOF, LE). Central Laos, Vientiane province, Vang Vieng district, Na Po village, about $12 \mathrm{~km}$ to the $\mathrm{W}$ of Vang Vieng town, Pa Nang Oua Mt., $18^{\circ} 55^{\prime} 44.9^{\prime \prime} \mathrm{N}, 102^{\circ} 20^{\prime} 20.1^{\prime \prime} \mathrm{E}$, dry broad-leaved primary and secondary evergreen and semideciduous forest on limestone at 600-900 m, semi-woody epiphytic creeping vine 1-2 m long, flowers white with pink-purple center, very fragrant, occasional, 17 March 2013, N. T. Hiep et al., LA-VN 544 (FOF, 


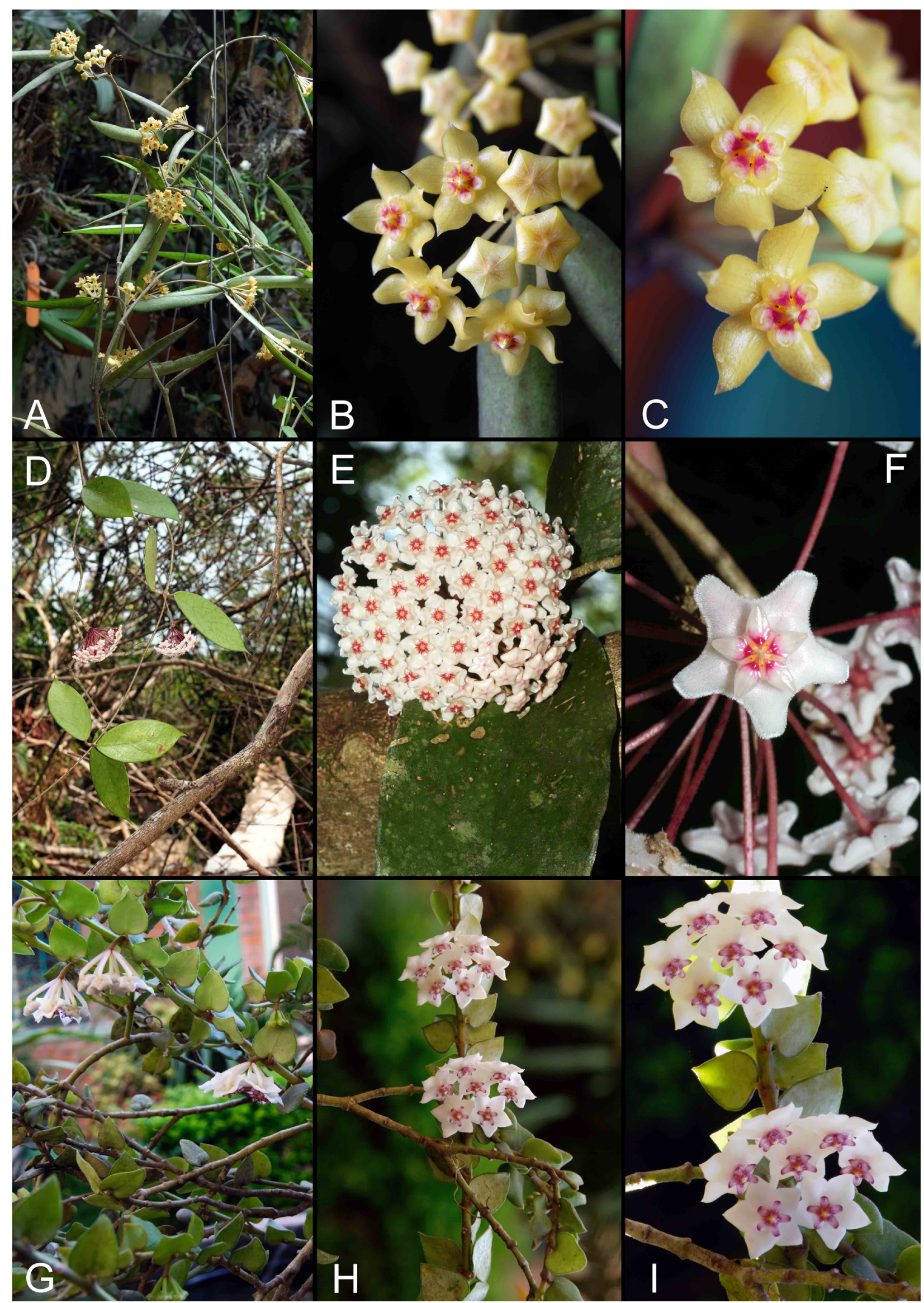

Fig. 3. Hoya burmanica Rolfe: A-C (C. X. Canh, s. n., photos by C. X. Canh). H. carnosa L. f.) R. Br.: D-F (D, F LA-VN 544, photo V. T. Pham; E - LA-VN 1491, photo L. Averyanov). H. chinghungensis (Tsiang et P. T. Li) M. G. Gilbert, P. T. Li et W. D. Stevens: G-I (C. X. Canh, s. n., photos by C. X. Canh). 
LE). Northern Vietnam, Hoa Binh province, Lac Son district, Tu Do municipality, Mon village, around point $20^{\circ} 25^{\prime} 29^{\prime \prime} \mathrm{N}, 105^{\circ} 19^{\prime} 3^{\prime \prime} \mathrm{E}$, primary broad-leaved forest on limestone at $500-700 \mathrm{~m}$, semi-woody vine, occasional, 25 March 2011, N. Q. Hieu et al., CPC 1592d, fl. et coll. under cultivation at May 2014, flowers very fragrant, white, corona pink (LE). Northern Vietnam, Quang Binh province, Minh Hoa district, Thuong Hoa municipality, $17^{\circ} 41^{\prime} 28^{\prime \prime} \mathrm{N}, \quad 105^{\circ} 53^{\prime} 42.7^{\prime \prime} \mathrm{E}$, rocky slope of limestone mountains, in primary closed evergreen broad-leaved lowland forests at $582 \mathrm{~m}$, semi-woody vine to $3 \mathrm{~m}$ long on mossy exposed rock, flowers white, light pinkish, common, 5 August 2011, N. T. Hiep et al., CPC 3959 (LE). Northern Vietnam, Quang Ninh province, Ha Long Bay, $20^{\circ} 54^{\prime} \mathrm{N}$, $107^{\circ} 08^{\prime} \mathrm{E}$, secondary limestone forest at $0-100 \mathrm{~m}$, epiphyte and lithophyte with white latex, corona center purple, common, 8 July 2003, P. V. The, N. X. Tam, NTH 5749 (HN). Central Vietnam, Quang Tri province, Huong Hoa district, Huong Viet, Sa Duong, Sa Lit River, 16051'N, 106 $34^{\circ}$ E, at $650 \mathrm{~m}$, vine $3 \mathrm{~m}$ long, 1 April 2006, N. Tap, N. V. Trai, HLF 6420 (HN, LE).

Hoya chinghungensis (Tsiang et P. T. Li) M. G. Gilbert, P. T. Li et W. D. Stevens,

1995, Novon 5, 1: 9; Li et al., 1995, Fl. China 16: 236 .

$\equiv$ Dischidia chinghungensis Tsiang et P. T. Li, 1974, Acta Phytotax. Sin. 12, 1: 130, pl. 31.

Fig. 3G-I.

Described (Tsiang, Li, 1974) from southern China ("China, Yunnan, che-li HGsien, Meng soong, Dah-Meng-Lung, 1900 m"). Type ("Sep. 1936, C. W. Wang 78311") - IBSC (holotype), A (isotype).

Vernacular name in Vietnam. Cẩm cù hoa tán.

Habitat, phenology and conservation status. Humus epiphytic or occasionally lithophytic undershrub with arching and pendulous shoots to 2 $\mathrm{m}$ long. Primary broad-leaved evergreen forests on any kind of soils, but preferably on rocky limestone, commonly on mountaintops, $700-1500 \mathrm{~m}$. Fl. April - August. Locally common. Estimated IUCN Red List status - VU.

Distribution. Laos (Vientiane province), Vietnam (Dien Bien, Ha Giang, Lai Chau and Son La provinces). China, Thailand.

Notes. This is the first record of this rare species for the flora of Laos and Vietnam. It is part of a group of rather similar species including Hoya dickasoniana P. T. $\mathrm{Li}(\mathrm{Li}, 1994), H$. weebella Kloppenb. (Kloppenburg, 2005), H. lanceolata D. Don (Don, 1825), H. vaccinioides Hook. f.
(Hooker, 1883), H. engleriana Hosseus (Hosseus, 1907) and H. kingdonwardii P. T. Li (Li, 1994) that have not been worked out yet but appear to have very similar flower morphology, but a few taxa can be separated based on lamina shape. Hoya chinghungensis is the only species in the complex bearing almost round leaves. In Laos and Vietnam $H$. chinghungensis is a very sensitive, highly endangered element of the fast decreasing primary woods and desire status of vulnerable. The collecting as ornamental plant due to market demands is additional factor of its extinction.

Studied specimens. Central Laos, Vientiane province, Kasi district, Thong Mout village, Num Pong Mt., $19^{\circ} 21^{\prime} 46.9^{\prime \prime} \mathrm{N}, 102^{\circ} 09^{\prime} 29.8^{\prime \prime} \mathrm{E}$, primary and secondary broad-leaved evergreen forest on steep shale slopes along stream at about $900 \mathrm{~m}$, creeping epiphytic vine to $2 \mathrm{~m}$ long on tall tree, not common, 22 March 2013, L. Averyanov, N. S. Khang, S. Lorphengsy, LA-VN 728 (LE, FOF, HNL). Northern Vietnam, Dien Bien province, Tua Chua district, Sin Chai municipality, $22^{\circ} 03^{\prime} 38^{\prime \prime} \mathrm{N}$, $103^{\circ} 19^{\prime} 56^{\prime \prime} \mathrm{E}$, primary humid evergreen broadleaved forest on very steep rocky slopes and on tops of remnant mountain composed with highly eroded marble-like solid crystalline limestone at 1350-1500 m, creeping pendent epiphyte on old mossy tree on top of ridge, locally common, 14 December 2010, L. Averyanov et al., CPC 951 (LE). Northern Vietnam, Dien Bien province, Muong Cha district, Hua Ngai municipality, $\mathrm{Ha} \mathrm{La}$ Chu village, $21^{\circ} 53^{\prime} 46^{\prime \prime} \mathrm{N}, 103^{\circ} 10^{\prime} 17^{\prime \prime} \mathrm{E}$, highly degraded primary evergreen broad-leaved humid forest on very steep slopes of remnant mountains composed with solid limestone at 1100-400 m, epiphyte on tall mossy tree, common, 7 April 2011, L. Averyanov et al., CPC 2049a (LE). Northern Vietnam, Ha Giang province, Vi Xuyen district, Tung Ba municipality, Khau Ca nature reserve, primary broad-leaved humid evergreen forest on limestone at 700-1150 m, $22^{\circ} 50^{\prime} 39.4^{\prime \prime} \mathrm{N}, 105^{\circ} 07^{\prime} 50.3^{\prime \prime} \mathrm{E}$, epiphytic liana, 80 $\mathrm{cm}$ in long, flower white, 8 May 2015, N. Q. Hieu et al., CPC 7738 (LE). Northern Vietnam, Lai Chau province, Sin Ho district, Phin Ho municipality, Ta Genh village, $22^{\circ} 28^{\prime} 26^{\prime \prime} \mathrm{N}, 103^{\circ} 16^{\prime} 31^{\prime \prime} \mathrm{E}, 1285 \mathrm{~m}$, upper slopes and ridges of limestone mountains, epiphyte, rare, June 2006, P. K. Loc et al., HAL 8771 (HN, LE, MO). Northern Vietnam, Son La province, Mai Son district, Chieng Kheo commune, 2 May 2011, C. X. Canh s. n. (LE - photos).

Hoya crassipetiolata Aver., V. T. Pham et T. A. Le, sp. nov.

Fig. 4, 5 . 
Type ("15 July 2016, L. Averyanov, T. Maisak, CPC 2049a") - LE (holotype, isotypes), herbarium specimen prepared from cultivated plant collected in N. Vietnam ("Dien Bien province, Muong Cha district, Hua Ngai Municipality, Ha La Chu village, around point $21^{\circ} 53^{\prime} 46^{\prime \prime} \mathrm{N}, 103^{\circ} 10^{\prime} 17^{\prime \prime} \mathrm{E}$, primary evergreen broad-leaved humid forest on very steep slopes of remnant mountains composed with solid limestone at elevations $1100-1400 \mathrm{~m}$ a. s. 1., epiphyte on tall mossy trees, common, 7 April 2011, L. Averyanov et al., CPC 2049"). Plate: digital Vietnamese flora 0257/CPC 2049a, fig. 5.

Etymology. Species name refers to the remarkably thick leaf petiole.

Vernacular name in Vietnam. Cẩm cù đá.

Description. Epiphytic and lithophytic vine with milky latex (1.5)2-4(6) m long. Stem dull green to dull pale brownish-grey, slender, wiry, flexuose, terete, slightly thickened at nodes, (1.6)2-2.8(3.2) $\mathrm{mm}$ in diam., glabrous, twining or climbing by many adventitious roots; leafy almost throughout; internodes (5)18-15(18) cm long. Leaves glabrous, decussate, petiolate. Petiole very thick (often twice thicker than stem), dark green when young, later dull brownish-grey, barky, usually strongly curved or twisted, (0.8)1-1.8(2) cm long, (2.8)3-4.5(5) $\mathrm{mm}$ in diam., semi terete in cross section, shallowly broadly grooved adaxially; young petioles at apex with pair of small whitish colleters, later maturing into prominent hemispheric barky callus (1)1.5-2 $\mathrm{mm}$ tall. Leaf blade fleshy coriaceous, rhomboid elliptic, (4.5)5.5-9.5(10.5) cm long, (2.2)2.5-4(4.5) $\mathrm{cm}$ wide, slightly curved, shortly acuminate at base and apex, uniform green or green/white tessellated above, light pale green to almost white below, adaxially with distinct dark green midvein and 3-5 pairs of irregularly arching and branching lateral veins, abaxial surface with prominent green midrib and hardly visible lateral veins. Inflorescence an extra-axillary many-flowered umbel; peduncle rather stout, spreading or pendulous, cylindrical, (2)3-6(8) cm long, (2)3-4(4.5) $\mathrm{mm}$ in diam., dull to dark greenish or brownish, glabrous; rachis swelling, perennial, growing up to $10(15) \mathrm{mm}$ long and $5 \mathrm{~mm}$ in diam., forming flower sets time to time during $2-3$ (or more) years; pedicels greenish-white, cylindrical, slender, (1.6)1.8-2(2.2) $\mathrm{cm}$ long, 1-1.2 $\mathrm{mm}$ in diam., glabrous, sometime very finely granulose. Flowers odorless. Calyx flat, (4.4)4.6-4.8(5) $\mathrm{mm}$ in diam., glabrous or very finely granulose, of 5 sepals almost free at base, sepals light pale dull olive-greenish, triangular ovate, obtuse to blunt, (1.4)1.5-1.6(1.8) mm long,
(1.2)1.3-1.4(1.5) mm wide near base. Corolla of 5 petals, (1.5)1.6-1.7(1.8) $\mathrm{cm}$ in diam. when flattened, white, with greenish, pinkish or almost white lobes; petals strongly recurved, rhomboid, tube 1.8-2.2 $\mathrm{mm}$ long, free part (5.5)6-7(7.5) mm long, (4.2)4.5$4.8(5) \mathrm{mm}$ wide at middle, straight along margin, triangular acute at apex, inside densely papillose at the base, glossy glabrous in apical half, glabrous outside. Corona glossy, uniform pure white or with light pink tinge, of 5 lobes, (1.9)2-2.2(2.3) $\mathrm{mm}$ tall, (7.8) 8-8.8(9) $\mathrm{mm}$ in diam., grooved between lobes; lobes obliquely ellipsoid in outline, flat and little concave above, (3.6)3.8-4(4.1) $\mathrm{mm}$ long, (1.8)2$2.2(2.3) \mathrm{mm}$ wide, at the base roundish with revolute margins, outer and inner processes obtuse, short, not reaching the style head apex. Style head discoid oblate, (1)1.1-1.2(1.3) $\mathrm{mm}$ tall, (2.1)2.2-2.4(2.5) in diam.; anther appendages yellowish; corpuscula chestnut-brown. Pollinarium: corpusculum narrowly rhomboid, angled, $0.2-0.25 \mathrm{~mm}$ long, $0.1-0.15 \mathrm{~mm}$ wide; translators very short, about $0.05 \mathrm{~mm}$ long; pollinia oblong, $(0.4) 0.5(0.6) \mathrm{mm}$ long, $0.1-0.15$ $\mathrm{mm}$ wide, yellow; germinating crest very narrow, light yellowish, hyaline, extending from translator to pollinium apex. Carpels 2, free, half bottle-shaped, densely connivent each other, $1.4-1.6 \mathrm{~mm}$ tall, $0.6-0.7 \mathrm{~mm}$ wide at the base, articulated apically to white, oblate stigma head, (0.7)0.8-0.9(1) $\mathrm{mm}$ tall, $2.2-2.4 \mathrm{~mm}$ in diam.

Habitat, phenology and conservation status. Creeping epiphytic and lithophytic herbaceous to semi-woody vine to $6 \mathrm{~m}$ long. Secondary evergreen broad-leaved lowland forests on sandy soils along seashore and primary broad-leaved evergreen forests on rocky karstic limestone, often on steep slopes and cliffs near mountaintops, 10-1400 m. Fl. May - August. Locally common. Estimated IUCN Red List status - DD.

Distribution. Vietnam (Bac Kan, Dien Bien, Khanh Hoa, Quang Binh and Quang Tri provinces). Endemic.

Notes. This new species is rather similar in leaf and flower morphology to Hoya hainanensis Merr. (Merrill, 1923) because both species have rhomboid elliptic leaves with a decussate base, reflexed corolla and ellipsoid corona lobes. The two species can be separated by the upper surface of the corona lobe that is flat in $H$. crassipetiolata (vs. sunken) and the inner process of the corona lobe that is obtuse, short (vs. apiculate and recurved upwards). In its floral morphology $H$. crassipetiolata is also very similar to H. pachyclada Kerr (Kerr, 1939) widely distributed in Thailand and Cambodia. However, it is totally 


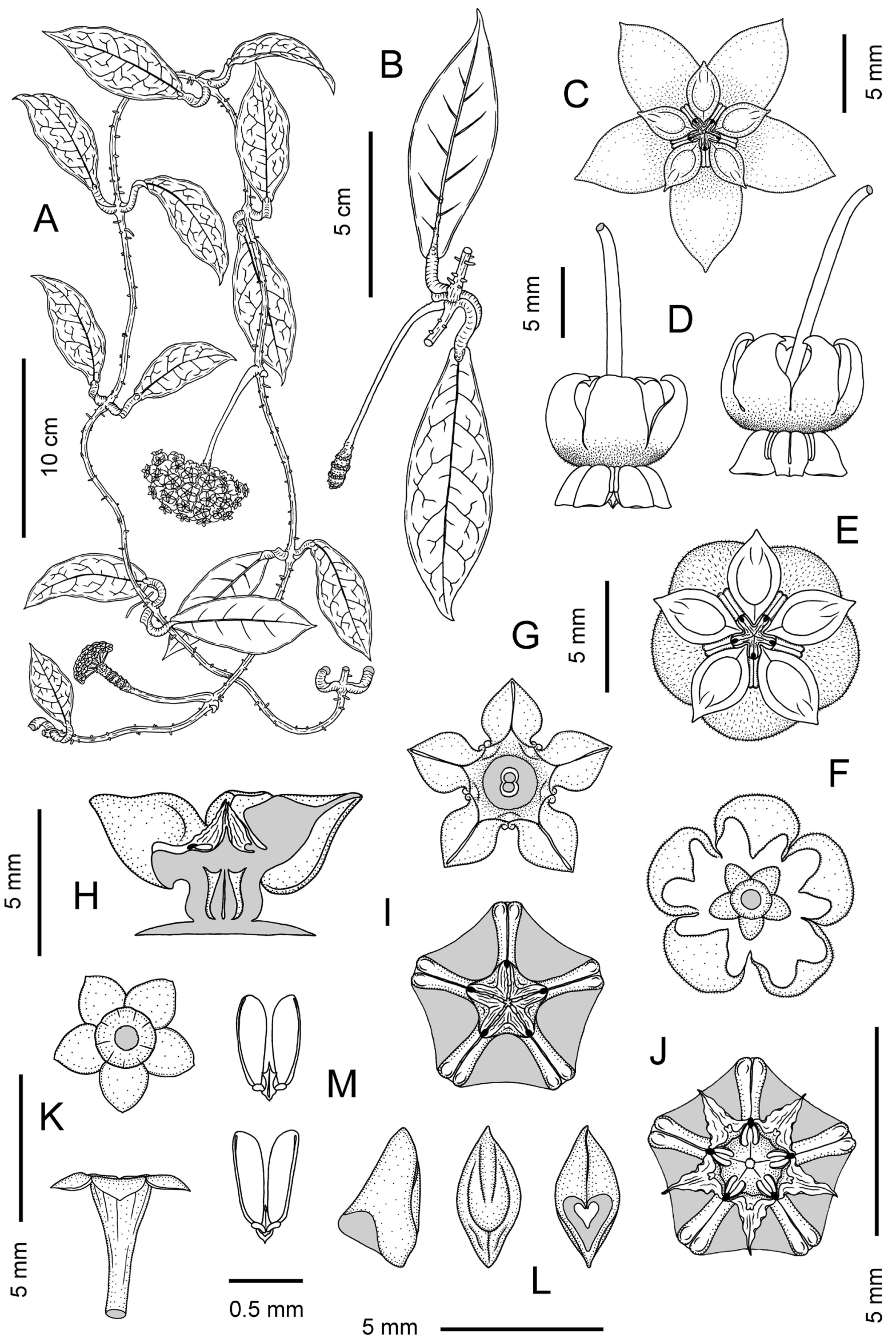

Fig. 4. Hoya crassipetiolata Aver. et V. T. Pham. Drawn from the type (CPC 2049a), by L. Averyanov and T. Maisak. 


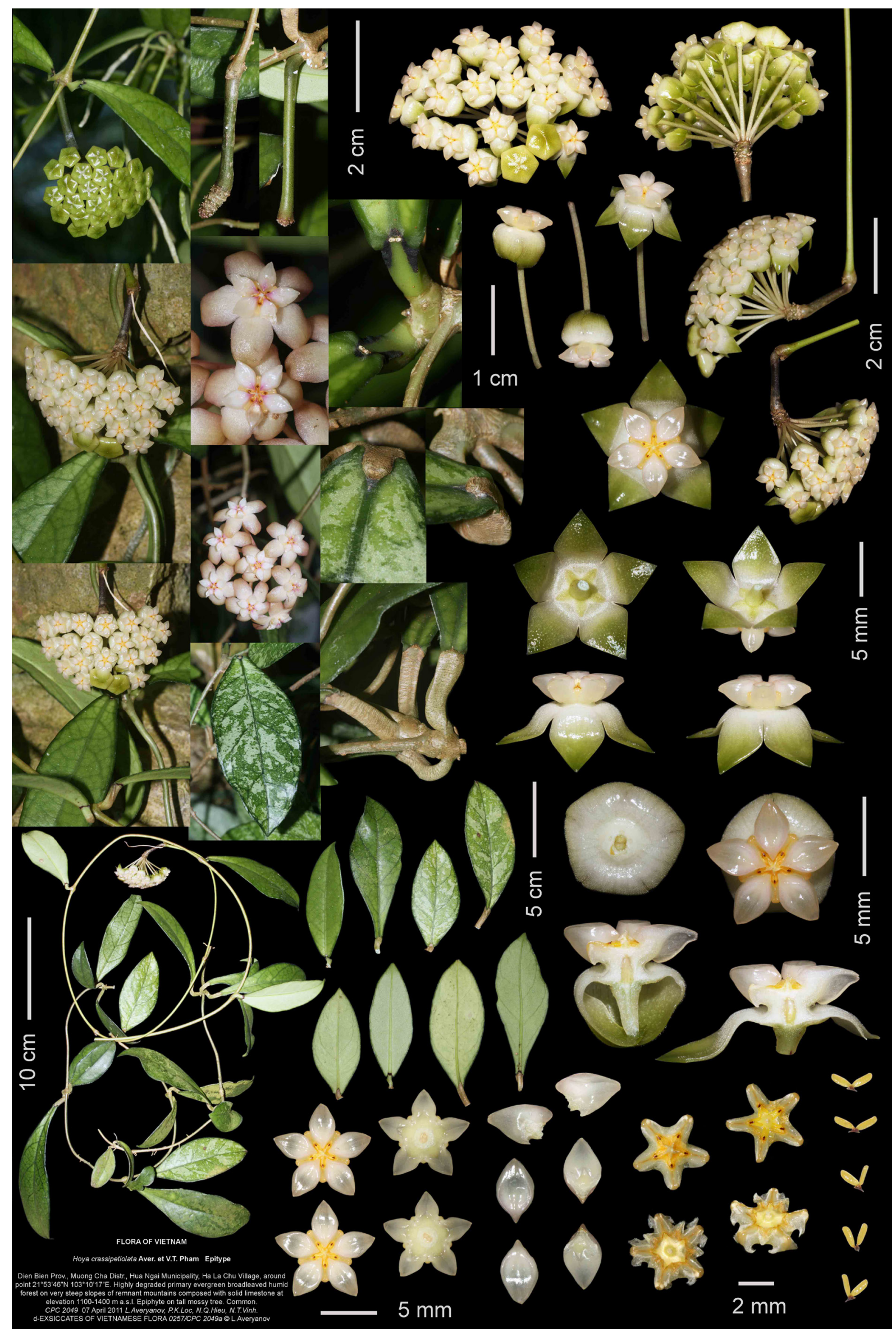

Fig. 5. Hoya crassipetiolata Aver. et V. T. Pham. Digital Vietnamese flora 0257/CPC 2049a. Photos, correction and design by L. Averyanov and T. Maisak. 
different in its vegetative habit. Described plant is slender herbaceous or semi lignified vine (not undershrub with rather robust stems), glabrous in all parts (vs. sparsely pubescent leaves, peduncle, pedicels and calyx), coriaceous (not fleshy) leaves and glabrous corona base (not densely hairy with long hairs). It may be also close to $H$. verticillata (Vahl) G. Don s. 1., including H. acuta Haw. (Haworth, 1821) and $H$. parasitica Wall. ex Wight (Wight, 1834) widely distributed in tropical Asia, but well differs in rather sparse, not many-flowered umbels, larger flowers with strongly recurved broad petals, broadly ellipsoid corolla lobes with rather obtuse outer angle and prominent, irregularly branching secondary veins on leaf blade. The species superficially resembles the type specimens of $H$. oblongacutifolia Costantin (Costantin, 1912) [P00639820, P05207933, P00639821, P00639822] in character of leaf size and venation, but quite differs in distinct prominent secondary veins (hardly visible in leaves of $H$. oblongacutifolia), glabrous pedicels (not hairy) and bigger flower with corolla $1.5-1.6 \mathrm{~cm}$ in diameter (not about $1.2 \mathrm{~cm}$ across recorded for H. oblongacutifolia). The new species may be also easily distinguished by its unusually thick petioles (twice thicker as stem) and usually quite distinct green/white tessellation of adaxial surface of leaf blade. The species is easily cultivated and may be recommended as a fast growing ornamental plant.

A collection from Khanh Hoa province (2014, N. V. Canh s. n.) is intermediate between $H$. crassipetiolata and $H$. hainanensis; the inner process of the corona lobe is acute (as in H. hainanensis), but the corona lobes are flat (as in H. crassipetiolata).

Studied specimens (paratypes). Northern Vietnam, Bac Kan province, Cho Don district, Ban Thi municipality, Phia Khao village, Lung Li valley, $22^{\circ} 16^{\prime \prime} 10^{\prime \prime} \mathrm{N}, 105^{\circ} 31$ '01 'E, Cot Moc Mt., 800-900 $\mathrm{m}$, primary broad-leaved evergreen closed forest on limestone ridge, herbaceous or hemi-woody vine 4-6 m long, flowers white, disc light pink, not common, 23 May 2004, L. Averyanov al., HAL 4836 (HN, LE). Northern Vietnam, Quang Binh province, Minh Hoa district., Thuong Hoa commune, Ban On village, $17^{\circ} 40^{\prime} 21^{\prime \prime} \mathrm{N}, 105^{\circ} 57^{\prime} 59^{\prime \prime} \mathrm{E}$, 300-350 m, primary evergreen broad-leaved forests on limestone ridge, epiphyte, not common, 27 July 2011, P. K. Loc et al., CPC 5197 (HNU, LE - photo). Southern Vietnam, Khanh Hoa province, Nha Trang City area, Vung Ro Bay, 2014, N. V. Canh s. n. (LE - photos). Southern Vietnam, Quang Tri province, Hai Lang district, Hai Duong commune, $16^{\circ} 43^{\prime} 28.84^{\prime \prime} \mathrm{N}, 107^{\circ} 20^{\prime} 51.86^{\prime \prime} \mathrm{E}, 10-50 \mathrm{~m}$, sec- ondary evergreen broad-leaved forest on sandy swampy lowland near sea shore, creeping epiphyte to $5 \mathrm{~m}$ long, umbel of 11-28 flowers, flowers white mixed with light-yellow and light purple in center, fragrant, 5 August 2013, L. T. Anh, PVT QT 0092013 (HN, HNU, LE, LE - photos).

\section{Hoya erythrina Rintz,}

1978, Malayan Nat. Journ. 30, 3-4: 501, fig. 17.

Fig. 6A-C.

Described from southern part of Peninsular Malaysia ("Endemic to Malaya, in hill forests in Pahang and Selangor from $400-700 \mathrm{~m}$ and at Bertam, Ulu Kelantan; common but not abundant along rivers on both sides of The Gap"). Type ("Malaysia, Pahang, Sungai Teranum, $600 \mathrm{~m}$, alt. 25-9-1976, Rintz 117”') - L [L0004323] (holotype).

Vernacular name in Vietnam. Cẩm cù san hô.

Habitat, phenology and conservation status. Creeping epiphytic and lithophytic herbaceous or semi-woody vine to $5 \mathrm{~m}$ long. Primary and secondary broad-leaved evergreen forests, particularly on granite outcrops in humid places along streams, 300-500 m. Fl. November, occasionally all around the year. Locally common. Estimated IUCN Red List status - DD.

Distribution. Vietnam (Dak Lak and Khanh Hoa provinces). Thailand, Southern part of Peninsular Malaysia (Kelantan, Pahang and Selangor provinces).

Notes. This is a remarkable discovery of a rare species regarded earlier as occurring in peninsular Malaysia and Thailand only. The distance between its recorded locations in southern Vietnam and the locus classicus in Malaysia exceeds $1400 \mathrm{~km}$. $H$. erythrina is widely cultivated as an ornamental plant. Its flowers vary in color from white and yellowish to pink.

Studied specimens. Southern Vietnam, Dak Lak province, Chu Yang Sin Mountains, 2014, N. V. Canh s. n. (LE - photos). Southern Vietnam, Dak Lak province, Krong Bong district, $12^{\circ} 28^{\prime} 17^{\prime \prime} \mathrm{N}$, $18^{\circ} 02^{\prime} 45^{\prime \prime} \mathrm{E}, 400-500 \mathrm{~m}$, secondary evergreen forest on granite outcrops, epiphytic and lithophytic creeping vine to $5 \mathrm{~m}$ long in humid places along stream, flowers yellowish, common in Krong Bong district near Chu Yang Sin National Park and in M'Dak district near Ea So Natural Reserve, herbarium specimen prepared from cultivated plant collected from the wild, 18 November 2015, P. D. Q. Vuong, PVT DL 008-2015 (HN, LE, LE - photo). Southern Vietnam, Khanh Hoa province, Khanh Son district, en route from Cam Ran to Khanh Son, 


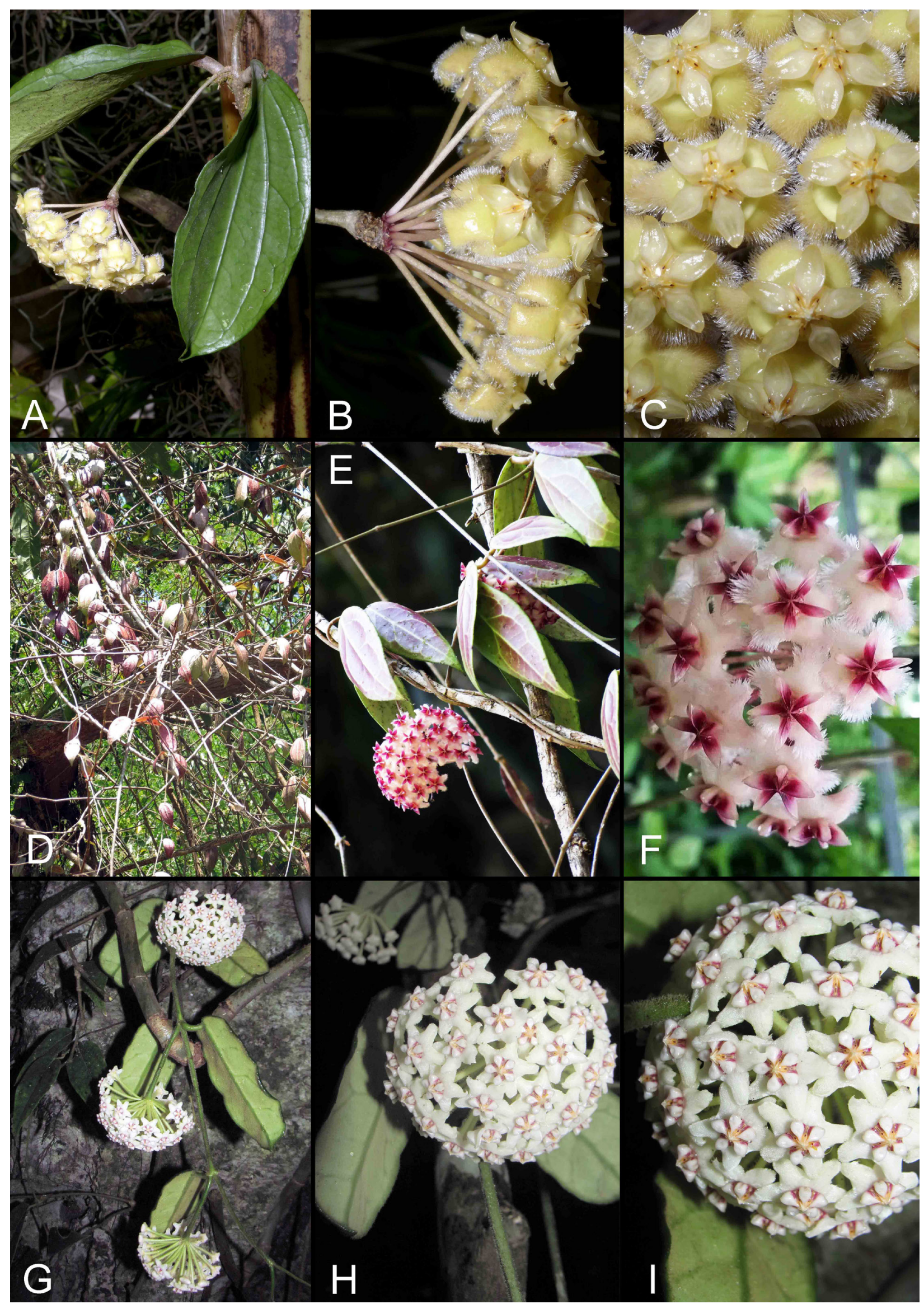

Fig. 6. Hoya erythrina Rintz: A-C (PVT DL 008-2015, photo by V. K. Nguyen). H. erythrostemma Kerr: D-F (N. V. Canh s. n., 2014, photo by N. V. Canh). H. globulosa Hook. f.: G-I (LA-VN 1117, photo of N. S. Khang). 
950 m, 19 May 1998, P.C. Boyce 1322, cultivated at the Royal Botanic Gardens Kew, acc. no. 19982780 , 31 July 2012, s. coll. (K [K000397245]).

\section{Hoya erythrostemma Kerr,}

1939, Bull. Misc. Inf. Kew. 8: 460; id., 1951. Fl. Siamensis Enum. 3, 1: 36.

Fig. 6D-F.

Described from peninsular Thailand. Lectotype ("Thailand, Tasan, C. B. Kloss 6909") - K [K000895112], lectotype designated by Rodda et al. (2014).

Habitat, phenology and conservation status. Creeping epiphytic herbaceous or semi-woody vine to $5 \mathrm{~m}$ long. Primary and secondary broadleaved evergreen lowland forests on alluvial soils. Fl. October - November, occasionally year round. Rare. Estimated IUCN Red List status - DD.

Distribution. Vietnam (Dak Lak province). Thailand.

Notes. H. erythrostemma was thought to be endemic to Thailand (Rodda et al., 2014) and with its discovery in Vietnam in Dak Lak province its range is extended about $500 \mathrm{~km}$ further eastwards.

Studied specimens. Southern Vietnam, Dak Lak province, Ea Kar district, Ea So nature reserve, primary and secondary lowland broad-leaved evergreen forest, N. V. Canh s. n., 2014 (LE - photos).

\section{Hoya fungii Merr.,}

1934, Lingnan Sci. Journ. 13: 68; Li et al., 1995, Fl. China 16: 233.

Fig. 7.

Described from S China. Type ("Hainan: Chim Shan, Fan Maan Ts'uen and vicinity, Ling shui (Ling-tui) district, growing on mountain side; semi-woody; 6 m.; fl. petals white center red; frag., Fung, H., 20137, May 3-20, 1932"), syntypes - A [A00076413], IBSC, PE [PE1642209-00029475, PE1642208-00029476]).

Vernacular name in Vietnam. Cẩm cù nấm.

Habitat, phenology and conservation status. Epiphytic and occasionally lithophytic semi-woody vine to $10 \mathrm{~m}$ long. Primary and secondary broadleaved evergreen forests on any kind of mother rocks, but preferably on rocky limestone, often on tall trees along streams and small rivers, $0-1200 \mathrm{~m}$. Fl. March - August, December. Locally common. Estimated IUCN Red List status - DD.

Distribution. Laos (Bolikhamsai, Champasak and Louangphrabang provinces), Vietnam (Dak Lak, Hai Phong, Hoa Binh, Quang Binh and Quang Tri provinces). S China (Guangdong, Guangxi, Hainan, Yunnan).
Notes. This species is new for the floras of Laos and Vietnam. It is similar in corolla and corona morphology to H. bonii Costantin (Costantin, 1912) and H. carnosa (L. f.) R. Br. (Brown, 1810). However, $H$. fungii differs from $H$. bonii in oblong elliptic (not cordate) glabrous leaves (young leaves and stems may be pubescent), which are bigger, longer and having distinct venation. The calyx lobes of $H$. fungii are lanceolate and pubescent while $H$. carnosa has shorter triangular calyx lobes. According to visual not documented observations of Mr Nguyen Van Canh, this species is also common in some areas of Dak Lak province. The plant is fast growing vine desirable for cultivation as ornamental plant.

Studied specimens. Northern Laos, Louangphrabang province, Pon Xay district, Houay Man village, Phou Pak Sang Mountain, 1959'03.8”N, $102^{\circ} 25^{\prime} 09.0^{\prime \prime} \mathrm{E}$, degraded primary evergreen and semideciduous forest on limestone at 1000-1150, creeping semi-woody epiphytic and lithophytic vine to $5 \mathrm{~m}$ long on mountain top, flowers pinkish, common, 4 April 2017, L. Averyanov et al., LA-VN 2034 (FOF, LE). Northern Laos, Louangphrabang province, Pon Xay district, between Houay Man and Nam Bo villages, Phou Hua Ben Toc Mountain, $19^{\circ} 57^{\prime} 33.1^{\prime \prime} \mathrm{N}, 102^{\circ} 25^{\prime} 25.8^{\prime \prime} \mathrm{E}$, degraded primary evergreen and semideciduous forest on limestone at 500-650 m, creeping epiphyte and lithophyte vine 4-6 m long on open mossy rocky mountain top, flowers pink, corona center purple, locally common, 5 April 2017, L. Averyanov et al., LAVN 2117 (FOF, LE). Central Laos, Bolikhamsai province, Thaphabat district, Nam Bon village, Phou Khao Khouay national park, Tad Xai Waterfall, $18^{\circ} 27^{\prime} 25.9^{\prime \prime} \mathrm{N}, 103^{\circ} 08^{\prime} 17.5^{\prime \prime} \mathrm{E}$, degraded primary and secondary evergreen dry forest along river on eroded sandstone at $340 \mathrm{~m}$, semi-woody epiphytic and lithophytic vine to $10 \mathrm{~m}$ long in rather open place, flowers sweet-spicy scented, white, center of corona pink, common, 11 April 2017, L. Averyanov et al., LA-VN 2193 (LE). Southern Laos, Champasak province, Paksong, Bolaven Plateau, $5 \mathrm{Km}$ south of Ban Phupakor, primary forest at the edge of precipice, epiphyte, sap transparent, originally collected 30 October 2015, M. Rodda, L. Tan, L. Guglielmone et al., MR 1739, flowered in cultivation, Singapore Botanic Gardens, 21 September 2016, M. Rodda, MR 1739 (SING). Northern Vietnam, Quang Binh province, Minh Hoa district, Hoa Son municipal-

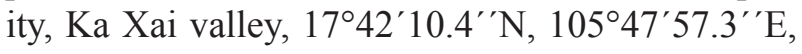
primary logged closed evergreen broad-leaved forest and woodland on wet shale valley at about 402 $\mathrm{m}$, epiphyte semi-woody vine; flowers white, or- 


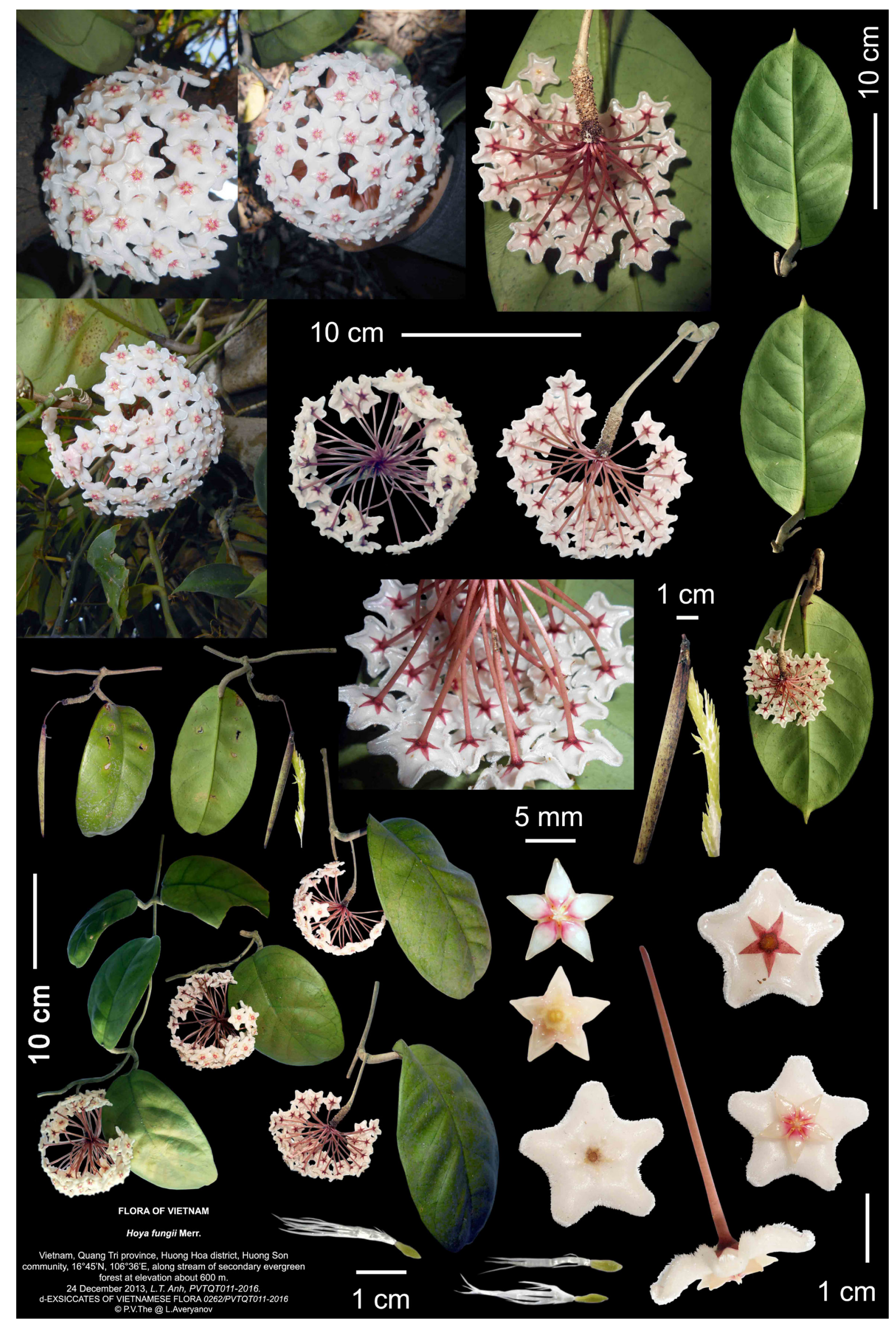

Fig. 7. Hoya fungii Merr. Digital Vietnamese flora 0262/PVT QT 011-2016. Photos by T. A. Le, correction and design by L. Averyanov. 
ange at center, peduncle purplish, common, $14 \mathrm{Au}$ gust 2011, N. T. Hiep, N. Q. Hieu, N. V. Tap et al., CPC 4196 (CPC Herbarium). Southern Vietnam, Dak Lak province, Chu Yang Sin Mountains, 2015, N. V. Canh s. n. (LE - photos). Southern Vietnam, Quang Tri province, sine loc., 2014, N. V. Canh s. n. (LE - photos). Southern Vietnam, Quang Tri province, Huong Hoa district, Huong Son community, $16^{\circ} 45^{\prime} \mathrm{N}, 106^{\circ} 36^{\prime} \mathrm{E}$, along stream of secondary evergreen forest at $600 \mathrm{~m}, 24$ December 2013, L. T. Anh, PVT QT 011-2016 (HN, LE, HNU). Plate: digital Vietnamese flora 0262/PVT QT 0112016, fig. 7.

\section{Hoya globulosa Hook. f.,}

1882, Gard. Chron. n. s. 17: 732, 741, fig. 115; Costantin, 1912, Fl. Indo-Chine 4: 140; Pham H. H., 2003, Ill. Fl. Vietnam 2: 748, fig. 6995; Tran T. B., 2005, Checklist Pl. Sp. Vietnam 3: 67.

Fig. 6G-I.

Described from NE. India ("Sikkim Himalaya"). Lectotype - icon: "Hoya globulosa" (Gard. Chronicle, 1882, n. s. 17: 741, fig. 115), lectotype designated by Jagtap and Singh (1999: 100).

$=H$. villosa Costantin, 1912, 1.c.: 137, syn. nov.

Vernacular name in Vietnam. Cẩm cù cầu.

Habitat, phenology and conservation status. Epiphytic and lithophytic creeping vine to $3 \mathrm{~m}$ long. Primary and secondary broad-leaved evergreen forests on any kind of mother rocks, often on karstic limestone, 800-950 m. Fl. March - April. Locally common. Estimated IUCN Red List status - DD.

Distribution. Laos (Houphan and Louangphrabang provinces), Vietnam (Ha Giang province). NE. India.

Collections cited below present new record of this species for the flora of Laos.

Studied specimens. Northern Laos, Houphan province, Viengxay district, Vieng Xai village, $20^{\circ} 23^{\prime} 41.3^{\prime \prime} \mathrm{N}, 104^{\circ} 13^{\prime} 44.5^{\prime \prime} \mathrm{E}$, primary and secondary broad-leaved evergreen dry forest on limestone at $800-950 \mathrm{~m}$, semi-woody vine $2-3 \mathrm{~m}$ long in rather open, exposed rocks, flowers white, sweet fragrant, corona inside purple, common, 7 April 2015, N. T. Hiep et al., LA-VN 1117 (FOF, HNL, LE). Northern Laos, Louangphrabang province, Muang Ngoi, disturbed primary forest on limestone, 350-400 m, terrestrial climber 3-4 mlong, C. Puglisi, M. Rodda, K. Souvannakhoummane, LAOS 75 (SING). Northern Vietnam, Ha Giang province, Vi Xuyen district, Tung Ba municipality, Khau $\mathrm{Ca}$ nature reserve, primary broad-leaved humid evergreen forest on limestone at 700-1150 $\mathrm{m}, 22^{\circ} 50^{\prime} 43.9^{\prime \prime} \mathrm{N}, 105^{\circ} 07^{\prime} 18.5^{\prime \prime} \mathrm{E}$, vine $3-5 \mathrm{~m}$ long, common, 9 May 2015, N. Q. Hieu et al., CPC 7822 (LE).

Hoya griffithii Hook. f.,

1883, Fl. Brit. India 4: 59; Li et al., 1995, Fl. China 16: 235.

Fig. 8A-C.

Described from NE. India based on two syntypes ("Khasia Mts., Griffith; Nowgong, alt. 2-4000 ft., J. D. H. et T. T."). Lectotype ("India, East Bengal, s. d., Griffith 3794") - K [K001045835], lectotype here designated.

Vernacular name in Vietnam. Cẩm cù khủng long.

Habitat, phenology and conservation status. Creeping epiphytic vine. Primary and secondary broad-leaved evergreen humid mountain forests, often with bamboo, on any kind of mother rocks, 900-1400 m. Fl. April - May, August - December. Not common. Estimated IUCN Red List status DD.

Distribution. Laos (Louang Namtha province), Vietnam (Dien Bien and Quang Ninh provinces). NE India, S China (Guangdong, Guangxi, Guizhou, Hainan, Yunnan), Thailand.

Note. The discovery of this rare species in highland areas of northern Vietnam and Laos is not much surprising. It was known before in NE India, S China and Thailand. Records listed here are the first for the flora of Vietnam. The species has large attractive flowers and may be recommended for cultivation as a fast, rather cool growing ornamental vine.

Studied specimens. Northern Laos, originally collected in Louang Namtha province, Louang Namtha, along the road to Muang Sing, 1000 m, evergreen broad-leaved forest mixed with bamboo on steep terrain, cultivated at the Singapore Botanic Gardens, vouchered as M. Rodda, MR 415 on 17 August 2013. Northern Vietnam, Dien Bien province, Muong Cha district, Hua Ngai municipality, $\mathrm{Ha} \mathrm{La}$ Chu village, $21^{\circ} 53^{\prime} 46^{\prime \prime} \mathrm{N}$, $103^{\circ} 10^{\prime} 17^{\prime \prime} \mathrm{E}$, highly degraded primary evergreen broad-leaved humid forest on limestone, 1100$1400 \mathrm{~m}$, creeping epiphyte on tall mossy tree, 7 April 2011, L. Averyanov et al., CPC 2049b (LE). Northern Vietnam, Quang Ninh province, with no exact locality, 2013, N. V. Canh s. n. (LE photos). Northern Vietnam, Quang Ninh province, Hoanh Bo district, Ky Thuong municipality, 900 $\mathrm{m}, 21^{\circ} 12^{\prime} \mathrm{N}, 107^{\circ} 09^{\prime} \mathrm{E}$, primary and secondary evergreen broad-leaved closed forest and bamboo- 


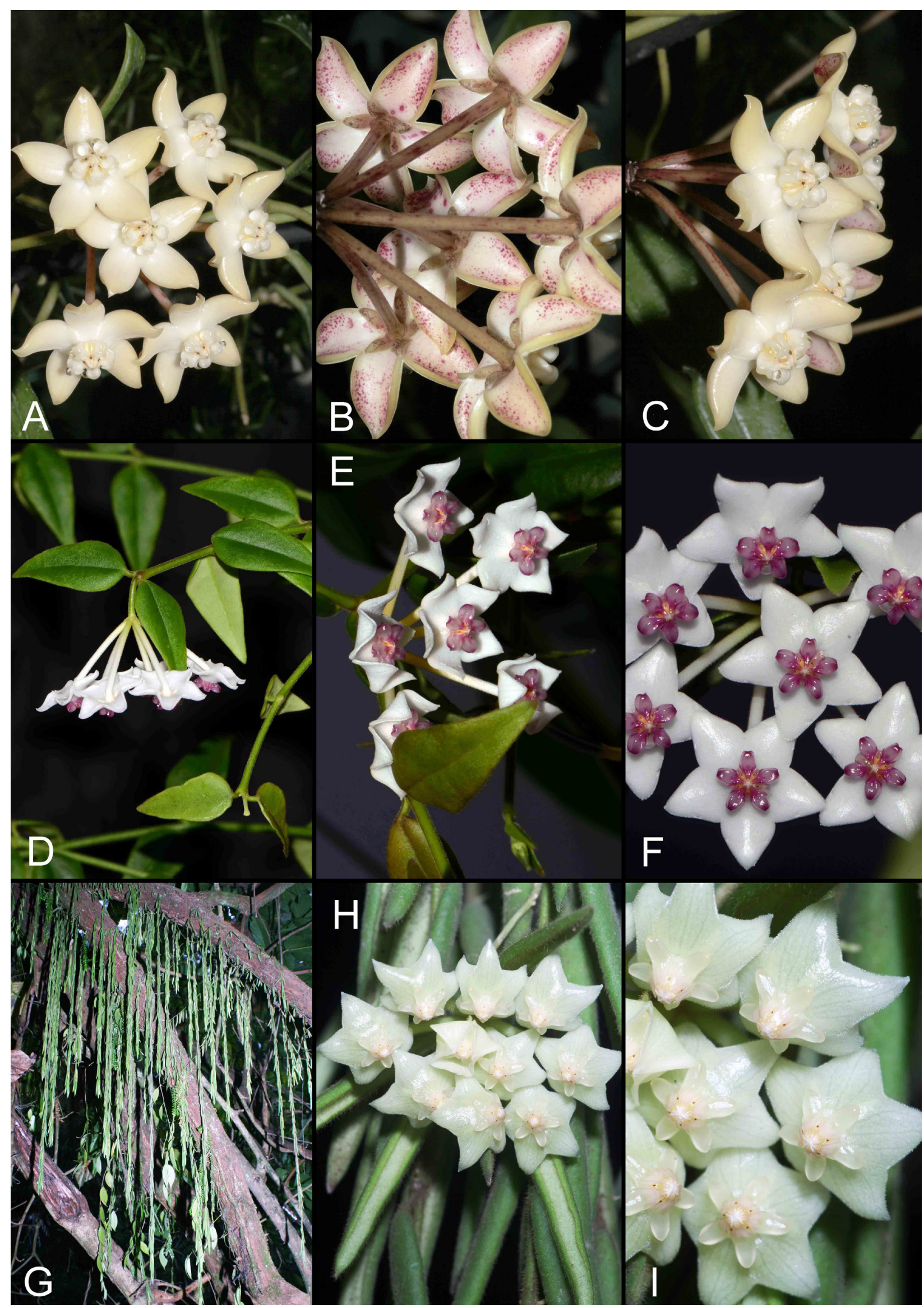

Fig. 8. Hoya griffithii Hook. f. - A-C (CPC 2049b, photos by L. Averyanov). H. lanceolata D. Don: D-F (12 July 1999, N. L. Orlov s. n., photos by N. L. Orlov). H. linearis Wall. ex D. Don: G-I (HAL 10694, photos by L. Averyanov). 
mixed forest, along stream, epiphytic vine, occasional, 17 August 2015, N. V. Canh, N. T. Nhat, PVT QN 013-2015 (HN, LE).

Hoya hainanensis Merr., 1923, Philipp. Journ. Sci. 23: 263.

Fig. 9.

Described from China, Hainan ("China, Hainan, $\mathrm{S}$ slope of five finger mountains, growing on trunk of tree ..."). Type ("May 1922, McClure, F.A. 9759"), syntypes - A [A00076415, A00076416], IBSC [IBSC005678], MO [MO-024520], UC [UC366286], US [US00026725].

Description. Lithophytic vine with milky latex to $5 \mathrm{~m}$ long. Stems slender, rooting at nodes and internodes, green and hairy when young, light grey, glabrous when old, terete, $1.6-1.8 \mathrm{~mm}$ in diam., internodes up to $25 \mathrm{~cm}$ long. Leaves petiolate; petiole stout, twisted, grooved, sparsely hairy, 4-6 $\mathrm{mm}$ long, $2-2.5 \mathrm{~mm}$ in diam. Leaf blade elliptic to oblanceolate, more or less fleshy, 9-11 cm long, 4-5 cm in wide, slightly curved, attenuate at base and apex, above dark green, below light green, with distinct reticulate nerves on adaxial surface, hardly visible abaxially except keeled midrib, indistinct secondary veins about 4-6 pairs, extended to margin, few short hairs visible under magnification on midrib of both surfaces. Inflorescences round umbel extra-axillary, commonly of 8-30 flowers; peduncle cylindrical, stout, swollen at base and apex, hairy, 13-15 cm long, $1.5-4 \mathrm{~mm}$ in diam., green to dark green with some dirty purple marks; pedicels white speckled with purple, slender, 1.8-2 $\mathrm{cm}$ long, about $1 \mathrm{~mm}$ in diam. Flowers pure white with red-purple center. Calix of 5 segments; sepals triangular, acute at apex, about $1.2-1.4 \mathrm{~mm}$ long and wide. Corolla 5-lobed, about $1.4 \mathrm{~cm}$ in diam.; lobes fleshy, ovate, acute, adaxially pubescent, pure white, abaxially glabrous, dull white-purplish, $6 \mathrm{~mm}$ long, $3.8 \mathrm{~mm}$ wide, slightly reflexed, margin revolute. Corona white with red-purple center, of 5 segments, about $2.2-2.4 \mathrm{~mm}$ tall and $7-7.2 \mathrm{~mm}$ in diameter, sunken in surface; segments glossy, almost white with red-purple inner angle, outer angle acute and curved, inner angle apiculate, 2.2-2.4 mm tall, 2.1$2.2 \mathrm{~mm}$ wide. Gynostegium bears on top 5 pollinaria covered by membranous yellowish anther caps. Pollinarium of two pollinia connected by two short translators; corpusculum about $0.18 \mathrm{~mm}$ long, 0.09 $\mathrm{mm}$ wide, chestnut, narrowly rhomboid, angled, acute; pollinium oblong, bright yellow, about 0.6$0.7 \mathrm{~mm}$ long, $0.2-0.24 \mathrm{~mm}$ wide, $0.07-0.09 \mathrm{~mm}$ thick; with germinating crested extending from translator to pollinium apex. Carpels 2, free, half bottle shaped, about $1.5 \mathrm{~mm}$ tall, $0.6 \mathrm{~mm}$ in diam., densely connivent each other, light green-purplish, apex shortly cuspidate and joined to stigma head bottom.

Habitat, phenology and conservation status. Lithophytic and occasionally epiphytic creeping vine. Primary evergreen broad-leaved forests, often on granite outcrops along streams, $800 \mathrm{~m}$. Fl. January - February. Locally common. Estimated IUCN Red List status - DD.

Distribution. Vietnam (Dak Lak province). S. China (Hainan).

Notes. H. hainanensis was only known from Hainan Island. Its discovery in southern Vietnam considerably extends its known distribution area. This species is known insufficiently in the flora of Vietnam; hence we provide here its description based on Vietnamese material.

Studied specimens. Southern Vietnam, Dak Lak province, M'Drak district, Chu Mu Mountain, around point $12^{\circ} 41^{\prime} \mathrm{N}, 108^{\circ} 54^{\prime} \mathrm{E}$, primary evergreen forest, January 2016, N. V. Canh, L. T. N. Thanh, FOP/02/2016/Hoya (HNIP).

Hoya lanceolata D. Don,

1825, Prodr. Fl. Nepal.: 130.

Fig. 8D-F.

Described from Nepal ("Hab. In Nepalia"). Lectotype ("Wallich") - BM [BM000521681], isolectotypes - BM [BM000574470], FI [FI009184]; lectotype here designated.

Habitat, phenology and conservation status. Epiphytic herb or undershrub with creeping or spreading shoots to $0.5 \mathrm{~m}$ long. Primary and secondary broad-leaved evergreen submontane forests, 1200-1300 m. Fl. June - July. Very rare. Estimated IUCN Red List status - DD.

Distribution. Vietnam (Lai Chau province). Nepal, NE India, Myanmar, N Thailand.

Notes. Very rare ornamental plant closely related to the widely cultivated $H$. bella Hook. (Hooker, 1848 , t. 4402), which is sometimes regarded as a subspecies of $H$. lanceolata D. Don subsp. bella (Hook.) D. H. Kent (Kent, 1981).

Studied specimens. Northern Vietnam, Lai Chau province, Than Uyen district, 1250 m, 12 July 1999, N. L. Orlov s. n. (LE, LE - photos).

Hoya linearis Wall. ex D. Don,

1825, Prodr. Fl. Nepal.: 130; Li et al., 1995, Fl. China 16: 235.

Fig. 8G-I. 
Described from Nepal ("Hab. in Nepalia"). Syntypes ("Wallich 8155") - BM, E [E00288750], K [K001129095; K001129094]

Vernacular name in Vietnam. Cẩm cù rủ.
Habitat, phenology and conservation status. Branch and trunk epiphyte with pendulous shoots to $1 \mathrm{~m}$ long. Primary and secondary broad-leaved evergreen humid forests on any kind of mother

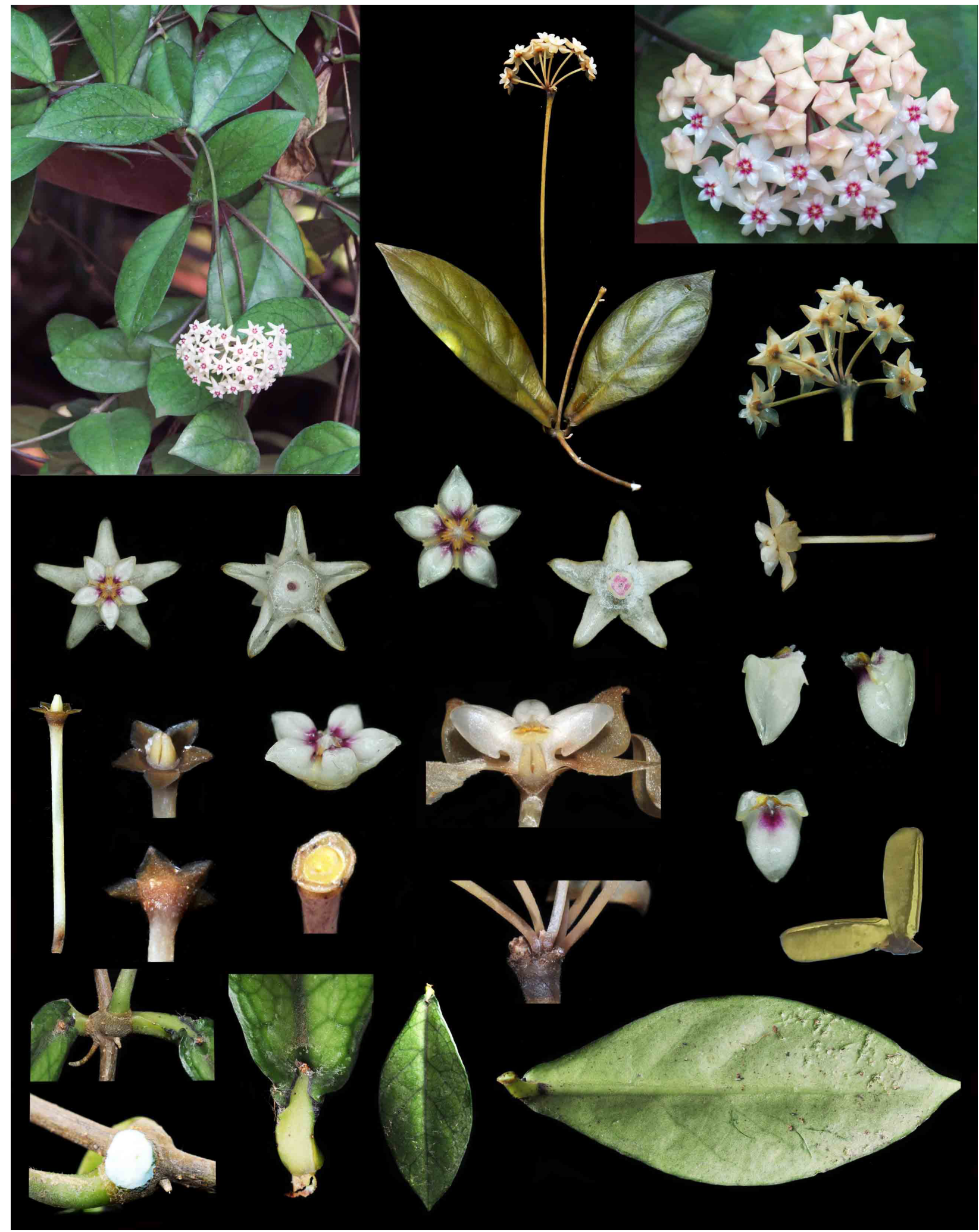

Fig. 9. Hoya hainanensis Merr. Plate made from FOP/02/2016. Photos, correction and design by N. V. Canh, H. T. Nguyen and V. T. Pham. 
rocks, commonly on old mossy trees on shady steep slopes along stream canyons, 900-1600(2000) m. Fl. September - October. Very rare. Estimated IUCN Red List status - DD.

Distribution. Laos (Vientiane province), Vietnam (Lao Cai and Lai Chau province). NE India, Nepal, Myanmar, SW China (NW Yunnan).

Notes. Easily distinguished species for its long slender herbaceous drooping shoots bearing densely hairy, almost terete leaves. Collected in Vietnam by Poilane as early as 1926 (Poilane 12932), but the specimen was until recently not identified to species.

Studied specimens. Northern Laos, Vientiane province, Kasi district, between San and Tham Tai villages, $19^{\circ} 17^{\prime} 47.9^{\prime \prime} \mathrm{N}, 102^{\circ} 08^{\prime} 58.9^{\prime \prime} \mathrm{E}$, secondary broad-leaved evergreen dry forest on limestone at 900-1000 m, epiphyte on tall mossy tree on steep shady stream slope, rare, 25 March 2017, L. Averyanov et al., LA-VN 1623 (LE). Northern Vietnam, Lai Chau province, Sin Ho district, Ta Ngao municipality, Hai Ho village, $22^{\circ} 16^{\prime} 09^{\prime \prime} \mathrm{N}$ $103^{\circ} 14^{\prime} 34^{\prime \prime} \mathrm{E}$, remnants of primary and secondary evergreen closed wet forest on limestone at 1500-1600 m, pendent epiphyte on mossy tree on very steep rocky wet shady slope, rare, 20 November 2006, N. T. Hiep, L. Averyanov, P. V. The, HAL 10051 (HN, LE, MO). Northern Vietnam, Lai Chau province, Phong Tho district, Sin Suoi Ho municipality, Sa Ma Pho village, $22^{\circ} 32^{\prime} 26^{\prime \prime} \mathrm{N}$ $103^{\circ} 32^{\prime} 05^{\prime \prime} \mathrm{E}$, secondary open evergreen broadleaved forest on very steep mountain slopes along rocky stream valley composed predominantly with weathered granite at 1000-1100 m, epiphyte with pendent shoots up to $1 \mathrm{~m}$ long on mossy tree along shady rocky stream valley, rare, 13 December 2006, N. T. Hiep, L. Averyanov, P. K. Loc et al., HAL 10694 (HN, LE, MO). Northern Vietnam, Lao Cai province, Sa Pa district, 14 August 1926, E. Poilane 12932 (P [P05207667]).

\section{Hoya lobbii Hook. f.,}

1883, Fl. Brit. India 4: 54.

Described from central India ("India, Nowgong, alt. 1500 ft."). Lectotype ("T. Lobb s. n.") - K [K000873093], lectotype here designated.

Habitat, phenology and conservation status. Humus epiphytic and lithophytic undershrub. Fl. November - December. Estimated IUCN Red List status - DD.

Distribution. Cambodia (Pursat province). India, Thailand.

Notes. H. lobbii is found in central India and Thailand and its record in neighbouring Cambodia is therefore not surprising.
Studied specimens. Western Cambodia, Pursat province, Veal Viang district, Phnom Samkos wildlife sanctuary, Yai Mau Shrine area, c. $5 \mathrm{~km}$ SW of Dei Kraham village, $12^{\circ} 12^{\prime} 34.6^{\prime \prime} \mathrm{N}, 102^{\circ} 53^{\prime} 50.0^{\prime \prime} \mathrm{E}$, $890 \mathrm{~m}$, in primary, evergreen, seasonal hard-wood forest on sandstone bedrock, evergreen lithophytic and epiphytic succulent vine, abundant white sap when cut, leaf blades glossy dark green above, pale green below, fruits light green, 12 March 2015, F. F. Merklinger 2015-6 (SING).

\section{Hoya lockii V. T. Pham et Aver.,}

2012, Nord. Journ. Bot. 30: 49, fig. 1; 2; 3A, B.

$=H$. poilanei Rodda, Simonsson et T. B. Tran, in sched. (P).

Described from central Vietnam ("Vietnam: Thua Thien - Hue province, A Luoi district, Huong Nguyen municipality, around point $16^{\circ} 06^{\prime} 04^{\prime \prime} \mathrm{N}$, $107^{\circ} 27^{\prime} 55^{\prime \prime} \mathrm{E}$, on tree in pristine primary evergreen broad-leaved and mixed forest, $1000 \mathrm{~m}$ a. s. 1."). Type ("12 May 2011, L. Averyanov, V. T. Pham, N. T. Vinh, CPC 3092") - CPC Herbarium (holotype), LE, VNM (isotypes). Plate: digital Vietnamese flora 0176/CPC 3092.

Vernacular name in Vietnam. Cẩm cù lộc.

Habitat, phenology and conservation status. Humus epiphytic undershrub. Primary evergreen broad-leaved, mixed and coniferous forests on any kind of mother rocks, commonly on tall trees in sunny canopy zones, 500-1200 m. Fl. May - August. Occasional. Estimated IUCN Red List status - DD.

Distribution. Vietnam (Quang Binh, Quang Tri and Thua Thien - Hue provinces).

Notes. This local Vietnamese endemic is close to the widespread species H. multiflora Blume (Blume, 1823). According to available collections, it is not rare in its limited area in central part of Vietnam. Ink and color illustrations of this species were presented in early publication (Pham, Averyanov, 2012).

Studied specimens. Northern Vietnam, Quang Binh province, Minh Hoa district, Hoa Son municipality, B'Lam Lang limestone mt., $17^{\circ} 42^{\prime} 15.8^{\prime \prime} \mathrm{N}, 105^{\circ} 48^{\prime} 24^{\prime \prime} \mathrm{E}$, primary closed evergreen broad-leaved forest on alluvial valley at 534 m, epiphyte, occasional, 16 August 2011, N. T. Hiep et al., CPC 4345 (LE, LE - photo), CPC 4383 (LE). Southern Vietnam, Quang Tri province, dent du Tigre, epiphyte with milky latex, 1200 m, 1924-5-7, E. Poilane 10301 (P [P00700447, P00700451]), 1100-1300, 1924-5-8, E. Poilane 10335 (P [P00700450, P00700453]), 11327 (P [P00700454]). Southern Vietnam, Quang Tri province, massif de Dong Che pres de Moi Lanh, 800 
m, epiphyte with milky latex, 1924-5-23, E. Poilane 10548 (P [P00700455, P00700448]. Southern Vietnam, Thua Thien - Hue province, Nui Bach Ma, 1000-1200 m, epiphyte, 1939-4-21, E. Poilane 29877 (P [P00700449]). Southern Vietnam, Quang Tri province, massif de Dong Tri, $950 \mathrm{~m}$, epiphyte, flowers white, 1924-6-17, E. Poilane 11021 (P [P00700452]). Southern Vietnam, Thua Thien Hue province, Bach Ma Mt., 1400 m, epiphyte, 1943-11-15, J. E. Vidal 682a (P [P00700440]). Southern Vietnam, Thua Thien - Hue province, A Luoi district, Hong Van municipality, Ta Lo village, $16^{\circ} 23^{\prime} 44^{\prime \prime} \mathrm{N}, 107^{\circ} 09^{\prime} 15^{\prime \prime} \mathrm{E}$, at $1000-1150 \mathrm{~m}$, secondary wet closed broad-leaved forest on very steep mountain slopes and edges of ridges composed with shale, epiphyte $1-2 \mathrm{~m}$ tall, not common, 1 May 2005, L. Averyanov et al., HAL 7708 (LE - photo).

Hoya loyceandrewsiana T. Green,

2008, Fraterna 21, 2: 22; id., 1994, Fraterna 4: 4, nom. invalid.

Fig. 10A-C.

Described on the base of cultivated plants of unknown origin (Green, 2008). Type ("USA, Hawaii, Kaaawa, Green Plant Research Nursery as T. Green 9301 in 1995") - BISH [BISH1016620] (holotype), NY [NY00991033] (isotype).

Habitat, phenology and conservation status. Epiphytic creeping semi-woody vine. Primary and secondary evergreen broad-leaved lowland forests. Fl. October - November. Very rare. Estimated IUCN Red List status - DD.

Distribution. Vietnam (Quang Ngai province). Endemic?

Notes. H. loyceandrewsiana was described based on cultivated material of unknown origin. This is the first discovery of the species in the wild.

Studied specimens. Southern Vietnam, Quang Ngai province, without exact locality, 6 June 2016, N. V. Canh, plant cultivated in private garden in Buon Ma Thuot City, herbarium specimen prepared in 12 October 2016 by N. V. Canh, L. Averyanov, T. Maisak, AL 239 (LE, LE - photos).

Hoya lyi H. Lév.,

1907, Bull. Soc. Bot. France. 54: 369; Rodda, 2012, Edinburgh Journ. Bot. 69: 85.

$-H$. mekongensis auct. non M. G. Gilbert: Li et al., 1995.

Fig. 10D-F, 11.

Described from SE. China ("Kouy-Tchéou: environse de Gan-Pin, 20 septembre 1897: sur parois des rochers surplombant une dépression en forme de cirque (L. Martin et Emile Bodinier); Lo-Pié, rocailles prés du marché, 7 octobre 1897 (Léon Martin et Séguin), $n^{\circ} 1853$; Tsien-Sen-Kiao, novembre 1904, n 1879 (Jean Ly)"). Lectotype ("Guizhou, Tsien-Sen-Kiao, November 1904, Ly 1879”) - E [E002794520], lectotype designated by Rodda (2012).

Vernacular name in Vietnam. Cẩm cù ly.

Habitat, phenology and conservation status. Epiphyte or lithophyte with creeping shoots to $2 \mathrm{~m}$ long. Primary broad-leaved and coniferous evergreen humid forests on any kind of mother rocks, 1000-2100 m. Fl. October - November. Locally common. Estimated IUCN Red List status - DD.

Distribution. N Laos (Houa Phan and Xiangkhouang provinces), Vietnam (Ha Giang, Lai Chau, Lam Dong, Lao Cai, Nghe An, Son La, Thanh Hoa and Tuyen Quang provinces). S China (Guangxi, Guizhou, Sichuan, Yunnan).

Notes. This miniature ornamental species may be easily recognized in nature even in sterile state by its small oval leaves and dense soft short indumentum on all plant parts. The species was previously recorded from China, Laos and from VietnamChinese border (Rodda, 2012). Presently recorded localities of this species are located almost throughout all mountain areas of Vietnam, and in Xiangkhouang and Houa Phan provinces of Laos. Cultivated specimens often develop much larger leaves to 18 cm long (vs. 2-4 cm in wild collections) with acute apex, longer scape and distinctly longer pedicels (Fig. 11).

Studied specimens. Northern Laos, Houa Phan province, Vieng Thong district, Nam Et-Phou Louey Natural protected area, mountain ridges near Ban Phu Vieng, 9 June 2013, J. Leong-Skornickova et al., JLS 2452 (SING). Northern Laos, Houa Phan province, Vieng Thong district, Nam Et-Phou Louey Natural protected area, mountain ridges near Ban Phu Vieng, cultivated at the Singapore Botanic Gardens, 17 January 2014, M. Rodda, MR 542 (SING). Northern Laos, Xiangkhouang province, Tam La, 19-X-1920, Poilane 2138 (P [P00700446, P00700534]). Northern Laos, Xiangkhouang province, Peak district, Oran village, $19^{\circ} 38^{\prime} 53^{\prime \prime} \mathrm{N}$, $103^{\circ} 23^{\prime} 12^{\prime \prime} \mathrm{E}$, primary and secondary broad-leaved evergreen dry forest on shale sandstone slopes and along ridge edge at $1750-1850 \mathrm{~m}$, creeping epiphytic vine $2-3 \mathrm{~m}$ long on tall mossy tree, common, 2 April 2015, N. T. Hiep et al., LA-VN 907 (FOF, HNL, LE). Northern Vietnam, border area between Phieng Luong municipality (Ha Giang province, 


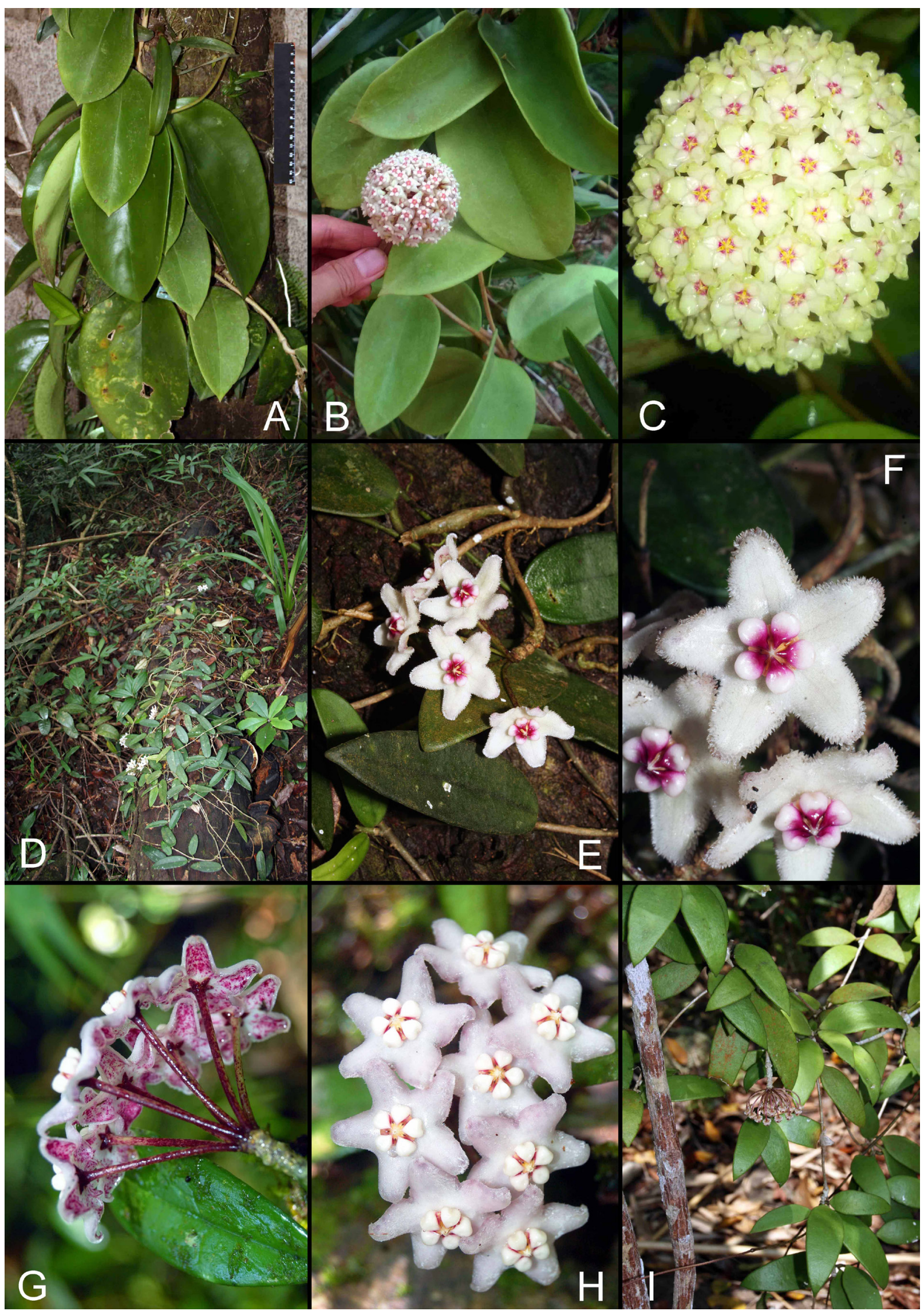

Fig. 10. Hoya loyceandrewsiana T. Green: A-C (N. V. Canh, L. Averyanov, T. Maisak, AL 239, photos by L. Averyanov and N. V. Canh). H. lyi H. Lév. - D-F (PVT XL 010-2015, photos of V. T. Pham). H. mengtzeensis Tsiang et P. T. Li: G, H (May 2015, Khoi s. n., photos of P. D. Q. Vuong). H. micrantha Hook. f.: I (LA-VN 2205, photos of L. V. Averyanov). 
Bac Me district) and Sinh Long municipality (Tuyen Quang province, Na Hang district) around point $22^{\circ} 38^{\prime} 24.3^{\prime \prime} \mathrm{N}, 105^{\circ} 20^{\prime} 21.3^{\prime \prime} \mathrm{E}, 14$ November 2014, L. Averyanov et al., CPC 7431a/TM 1138/TM 1138 (LE, fig. 11 - plate: digital Vietnamese flora 0254/CPC 7431a/TM 1138). Northern Vietnam, Ha Giang province, Yen Minh district, Lao Va Chai municipality, vicinities of Lao Va Chai village, $23^{\circ} 07^{\prime} \mathrm{N}, 105^{\circ} 08^{\prime} \mathrm{E}, 35.9 \mathrm{~km}$ to $27^{\circ}$ of Ha Giang city, primary wet evergreen broad-leaved closed forest on limestone ridge at 1300-1400 m, lithophytic creeping vine on open mossy rocks, white with deep violet center, common, 9 October 1999, N. T. Hiep et al., NTH 3470 (HN, K). Northern Vietnam, Lai Chau province, Sin Ho district, De Phin comm., around point $22^{\circ} 19^{\prime} 05.9^{\prime \prime} \mathrm{N}, \quad 103^{\circ} 13^{\prime} 53.8^{\prime \prime} \mathrm{E}$, degraded primary and secondary evergreen broadleaved forest on shaly limestone at $1600 \mathrm{~m}$, semiwoody creeping vine 2-4 m long, flowers, white, corona purple, 5 October 2016, L. Averyanov et al., CPC 8243 (LE - photo). Northern Vietnam, Lao Cai province, Bat Xat district, Yty village, $2000 \mathrm{~m}$, 14 October 2014, N. L. Orlov s. n. (LE - photos). Northern Vietnam, Nghe An province, Ky Son district, Na Ngoi municipality, eastern slopes of Phu Xai Lai Leng Mountains, primary broad-leaved and mixed forest (with Cunninghamia konishii) on very steep mountain slopes on granite at $1900 \mathrm{~m}$, $19^{\circ} 13^{\prime} 37.5^{\prime \prime} \mathrm{N}, 104^{\circ} 06^{\prime} 11.8^{\prime \prime} \mathrm{E}$, creeping epiphytic vine on mossy tree, flowers white, corona pinkishpurple, common, 20 October 2013, L. Averyanov et al., CPC 6030 (LE). Northern Vietnam, Son La province, Moc Chau district, Van Ho municipality, Hua Tat village, $20^{\circ} 46^{\prime} 18^{\prime \prime} \mathrm{N}, 104^{\circ} 47^{\prime} 29^{\prime \prime} \mathrm{E}$, broad-leaved evergreen forest with Pinus wangii and Podocarpus pilgeri on limestone at 1200-1350 $\mathrm{m}$, creeping herbaceous wine to $3 \mathrm{~m}$ long, flowers white to light pink with red center, not rare, 28 October 2006, N. T. Hiep, L. Averyanov, P. V. The, HAL 9310 (HN, LE). Northern Vietnam, Thanh Hoa province, Thuong Xuan district, Bat Mot municipality, Vin village, Xuan Lien nature reserve, primary broad-leaved evergreen wet forest on shale at $1000-1200 \mathrm{~m}, 19^{\circ} 58^{\prime} 18.2^{\prime \prime} \mathrm{N}, 104^{\circ} 59^{\prime} 24.0^{\prime \prime} \mathrm{E}$, creeping epiphytic vine on tall trees, flowers white, corona purple-violet, not common, 2 November 2013, L. Averyanov, N. T. Hiep, N. S. Khang, CPC 6598 (LE). Northern Vietnam, Thanh Hoa province, Thuong Xuan district, Bat Mot commune, Vin village, Xuan Lien nature reserve, primary evergreen broad-leaved forest, mixed with conifer species such as Fokienia hodginsii, Cunninghamia konishii, Dacrycarpus imbricatus, $19^{\circ} 57^{\prime} \mathrm{N}$, $105^{\circ} 04^{\prime} \mathrm{E}, 1000 \mathrm{~m}$, epiphyte creeping vine with white latex to $2 \mathrm{~m}$ long, in shade, umbels of 4-5 flowers, white, purple in center, not common, 3 November 2015, P. V. The, N. M. Toan, D. T. Anh, PVT XL 010-2015 (HN). Southern Vietnam, Lam Dong province, Lac Duong district, evergreen mountain forest, 10 October 2016, N. X. Son, L. Averyanov, T. Maisak, AL 234 (LE, LE - photos).

Hoya mengtzeensis Tsiang et $\mathrm{P}$. T. Li,

1974, Acta Phytotax. Sin. 12, 1: 120.

Fig. 10G, H.

Described (Tsiang, Li, 1974) from southern China ("China, Yunnan, Mengtze, Taitang"). Type (“23 May ?, A. Henry 11368”) - NY [NY00318643] (holotype), A [A00076419], E [E00275184], K [K000873050], MO [MO-2107366] (isotypes).

Vernacular name in Vietnam. Cẩm cù vân nam.

Habitat, phenology and conservation status. Epiphytic vine. Primary and secondary evergreen humid broad-leaved and coniferous forests on granite. Fl. April - June. Very rare. Estimated IUCN Red List status - DD.

Distribution. Vietnam (Lam Dong province). SW. China (Yunnan).

Notes. This is the first record of this rare species in Vietnam. The discovered locality in southern Vietnam is more than $1500 \mathrm{~km}$ (to the east south east) away from the main area of the species distribution in south-western Yunnan.

Studied specimens. Southern Vietnam, Lam Dong province, Bidoup - Nui Ba national park, May 2015, Khoi s. n. (LE - photo).

Hoya micrantha Hook. f.,

1883, Fl. Brit. India 4: 55; Rodda, Simonsson Juhonewe, 2013, Webbia 68, 1: 12.

Described from the southern part of peninsular Myanmar ("Tenasserim: Merguil"). Lectotype ("Myanmar, Tenasserim, Mergui, Griffith, W., 3798") - K [K000278011], lectotype designated by Rodda and Simonsson Juhonewe (2013).

$=H$. pseudovalifolia Costantin, 1912, Fl. IndoChine 4: 139.

- H. oblongacutifolia auct. non Costantin: Pham H.H., 2003, Ill. Fl. Vietnam 2: 750, fig. 7001.

Fig. 10I, 12A, B.

Vernacular name in Vietnam. Cẩm cù hoa nhỏ.

Habitat, phenology and conservation status. Creeping epiphytic and lithophytic vine to $10 \mathrm{~m}$ long. Primary and secondary dry broad-leaved evergreen lowland forests on any kind of mother rocks, commonly in open habitats, 20-500 m. Fl. March - May, October. Locally very common. Estimated IUCN Red List status - DD. 


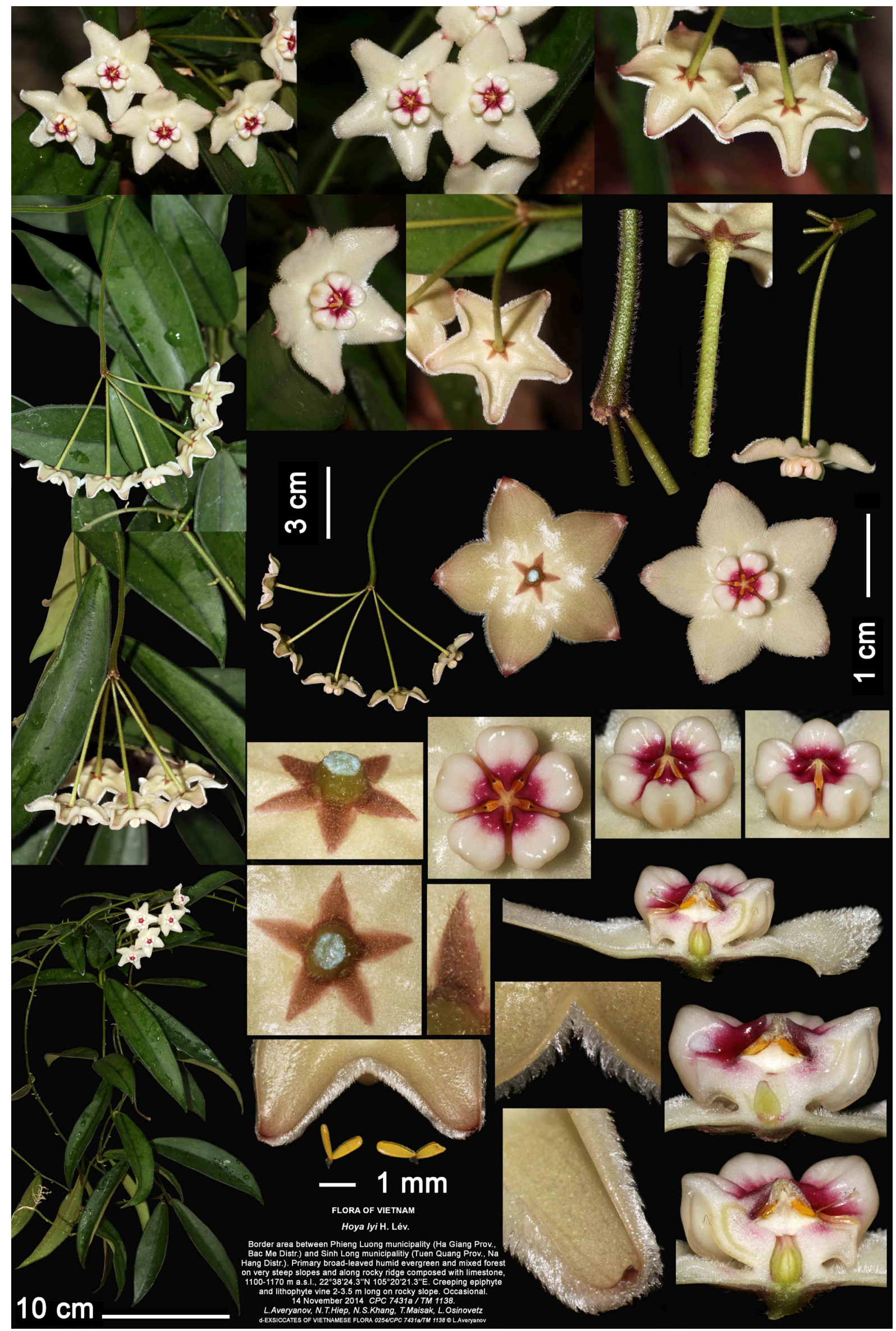

Fig. 11. Hoya lyi H. Lév. Digital Vietnamese flora 0254/CPC 7431a/TM 1138. Photos, correction and design by L. Averyanov and T. Maisak. 


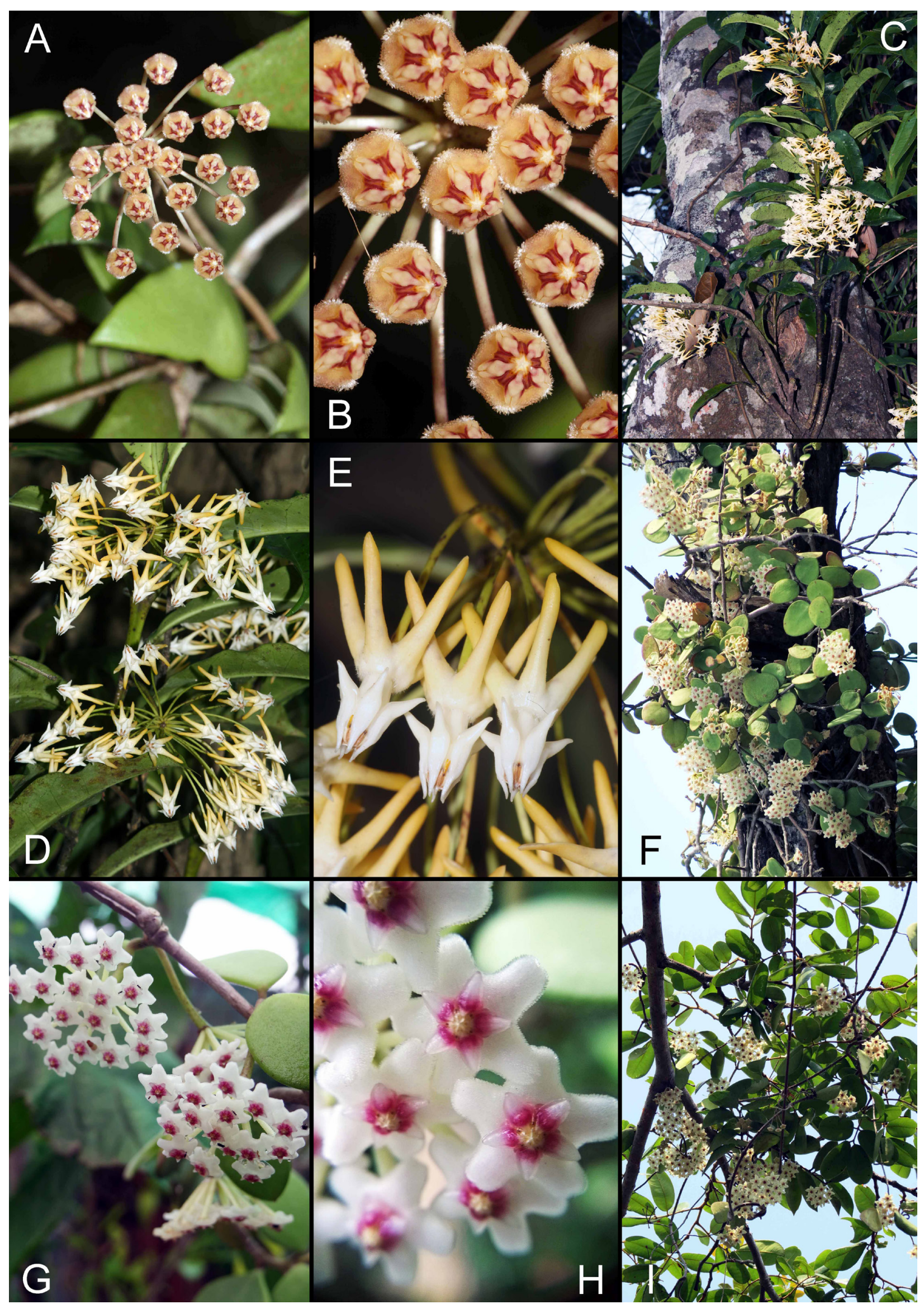

Fig. 12. Hoya micrantha Hook. f.: A, B (LA-VN 2205, photos of L. V. Averyanov). H. multiflora Blume: C-E (CPC 2433, photos of L. Averyanov). H. nummularioides H. Lév.: F-H (PVT DL 014-2015, photos of N. V. Canh). H. oblongacutifolia Costantin: I (2014, N. V. Canh, AL 241, photos of N. V. Canh). 
Distribution. Cambodia (Kampot and Sihanoukville provinces), Laos (Champasak, Bolikhamsai and Vientiane provinces), Vietnam (Ba Ria - Vung Tau, Dak Lak and Lam Dong provinces). Thailand, S Myanmar.

Notes. Presented data represent significant additional records of this rare species known earlier by few collections in southern Cambodia, Laos and Vietnam (Rodda et al., 2013).

Studied specimens. Southern Cambodia, to the N of Sihanoukville town, Kaoh Rong Samloem Khong Island in Siam Gulf, low hills, $10^{\circ} 36^{\prime} 45^{\prime}{ }^{\prime} \mathrm{N}$, $103^{\circ} 18^{\prime} 38^{\prime \prime} \mathrm{E}$, dry evergreen lowland forest, 19 November 2011, T. Maisak et al., 843a (LE - photo). Central Laos, Vientiane province, Vang Vieng district, Nathong village, about $5 \mathrm{~km}$ to the $\mathrm{W}$ of Vang Vieng town, Tham Kang Mt., $18^{\circ} 55^{\prime} 51.4^{\prime \prime} \mathrm{N}$, $102^{\circ} 23^{\prime} 50.6^{\prime \prime} \mathrm{E}$, dry broad-leaved primary and secondary evergreen forest on limestone mountains composed by solid crystalline limestone at $300-500$ $\mathrm{m}$, semi-woody epiphytic vine to $10 \mathrm{~m}$ long, flowers white, fragrant, corona purple, not common, 14 March 2013, N. T. Hiep, L. Averyanov, N. S. Khang et al., LA-VN 374 (FOF, HNL, LE, LE - photo). Central Laos, Bolikhamsai province, Thaphabat district, Nam Bon village, Phou Khao Khouay national park, Tad Xai Waterfall, 18 $27^{\circ} 25.9^{\prime \prime} \mathrm{N}$, $103^{\circ} 08^{\prime} 17.5^{\prime \prime} \mathrm{E}$, degraded primary and secondary evergreen dry forest along river on eroded sandstone at $340 \mathrm{~m}$, creeping semi-woody epiphytic vine 2-4 $\mathrm{m}$ long in rather open stream shrubs, flowers yellowish-pink, corona reddish-brown between lobes, very common, 11 April 2017, L. Averyanov et al., LA-VN 2205 (LE). Southern Laos, Champasak province, $\mathrm{Xe}$ Pian National protected area, secondary vegetation along stream with occasional Tectona, 25 October 2015, M. Rodda et al., MR1490 (SING). Southern Vietnam, Dak Lak province, Chu Yang Sin Mountains, 2014, N. V. Canh s. n. (LE - photos). Southern Vietnam, Dalat, 1960, Tixier 50 (P [P05391678]). Southern Vietnam, in montibus Dinh ad Baria in S. Cochinchine, 1866, Pierre 4329 (P [P00476431]).

\section{Hoya multiflora Blume,}

1823, Cat. Plant. Buitenzorg: 49; id., 1826. Bijdragen 16: 1064; Costantin, 1912, Fl. Indo-Chine 4: 128; Li et al., 1995, Fl. China 16: 230; Pham H.H., 2003, Ill. Fl. Vietnam 2: 749, fig. 6998; Tran T.B., 2005, Checklist Pl. Sp. Vietnam 3: 67; Newman et al., 2007, Checklist Vasc. Pl. Lao PDR: 70; The, Averyanov, 2012, Taiwania 57: 51, 53, fig. 3C, D.

Fig. 12C-E.
Described from Java ("Crescit: in fruticetis montanis Javae occidentalis"). Lectotype ("Indonesia, Java [prope flumine Tjapaes? Kietpil?, Salleh], 16 Sep 1820, s. coll., s. num.") - L [L0004333] designated by Rodda et al. (2017).

Vernacular name in Vietnam. Cẩm cù tên lửa.

Habitat, phenology and conservation status. Humus epiphytic undershrub. Primary broad-leaved evergreen forests on any kind of mother rocks, commonly on old tall trees, (500)600-1200 m. Fl. MarchJuly. Rare. Estimated IUCN Red List status - DD.

Distribution. Cambodia (Koh Kong province), Laos (Bolikhamxai, Houphan, Khammouan and Phongsali provinces), Vietnam (Hoa Binh, Gia Lai, Hai Phong area, Hanoi area, Kon Tum, Ninh Thuan and Quang Ninh provinces, "Cochinchina"). Myanmar, S. China (Guangxi, Yunnan), Thailand, Malaysia, Indonesia, Philippines.

Notes. Widespread and extremely variable species not too common in eastern Indochina. Here we report many more verified records of this species that were known before.

Studied specimens. Cambodia, Koh Kong province, Region deKamchay etmontagne del'Elephant, 1917-12, A. J. B. Chevalier 36428 (P [P00700445]). Cambodia, Koh Kong province, Region de Kamchay, Mont de l'Eléphant, 1919-8-11, E. Poilane 317 (P[P00700444]). Central Laos, Bolikhamxai province, Nape et Ban ho, December 1903, C. J. Spire 1484 (P [P05207687, P00700442, P00700488]). Central Laos, Khammouan province, Phon Thane, December 1903, C. J. Spire 1569 (P [P00700489, P00700490, P00700491]. Central Laos, Khammouan province, Nakai Nam Theun, $17^{\circ} 36^{\prime} 52^{\prime}{ }^{\prime} \mathrm{N}$, $105^{\circ} 43^{\prime} 15^{\prime \prime} \mathrm{E}, 835 \mathrm{~m}$, liana, 2006-5-22, M. F. Newman et al., 1216 (P [P05029369]). Central Laos, Khammouan province, Nakai Nam Theun, $17^{\circ} 38^{\prime} 33^{\prime \prime} \mathrm{N}, 105^{\circ} 44^{\prime} 9.996^{\prime \prime} \mathrm{E}, 1002 \mathrm{~m}, 2006-5-22$, M. F. Newman et al., 1422 (P [P00700439]. Northern Laos, Houphan province, Hem district, Nacoc village, Puphadeng mountain, $20^{\circ} 09^{\prime} 52.6^{\prime \prime} \mathrm{N}$, $103^{\circ} 10^{\prime} 19.4^{\prime \prime} \mathrm{E}$, primary and secondary broadleaved evergreen open dry forest on karstic limestone at 1000-1200 m, epiphytic undershrub on old trees on mountain top, not common, 12 April 2015, N. T. Hiep et al., LA-VN 1438 (FOF, HNL, LE). Northern Laos, Phongsali province, Muong May district, $21^{\circ} 12^{\prime} 32^{\prime \prime} \mathrm{N}, 102^{\circ} 53^{\prime} 44^{\prime \prime} \mathrm{E}$, highly degraded dry evergreen broad-leaved forest along tops of hill ridge composed with shale at 1250-1400 $\mathrm{m}$, epiphytic undershrub with erect stems to $1 \mathrm{~m}$ tall on old mossy tree, flowers white to light yellowish, not common, 22 April 2011, L. Averyanov, 
P. V. The, CPC 2433 (LE - photos). Northern Vietnam, Hai Phong City area, secondary evergreen broad-leaved lowland forest, 2014, N. V. Canh s. n. (LE - photos). Northern Vietnam, Hanoi area, Mont Bavi, 1888-6-9, B. Balansa 2086 (P [P00700484, P00700485, P00700486]). Northern Vietnam, Hanoi area, Mont Bavi, epiphyte, 1888-7-24, B. Balansa 2087 (P [P00700487]). Northern Vietnam, Hanoi area, Mont Bavi, epiphyte, 1940-6-4, P. A. Petelot 7197 (P [P00700492]). Northern Vietnam, Hoa Binh province, Lac Son district, Ngoc Son municipality, Khu village, $20^{\circ} 27^{\prime} 42^{\prime \prime} \mathrm{N}, 105^{\circ} 18^{\prime} 34^{\prime \prime} \mathrm{E}$, $611 \mathrm{~m}$, primary closed evergreen broad-leaved lowland forests on foothill of limestone mountains, occasional, epiphyte, 28 July 2006, P. K. Loc, N. S. Khang, N. T. Vinh, HAL 9037 (LE). Northern Vietnam, Quang Ninh province, Taai Wong Mo Shan and vicinity, Chuk-phai, Ha-coi, 1936-11, W. T. Tsang 27201 (P [P00700441]). Southern Vietnam, Dak Lak province, Chu Yang Sin Mountains, primary and secondary evergreen broad-leaved mountain forest, 2014, N. V. Canh, cultivated in private garden in Buon Ma Thuot City, photos of N. V. Canh, AL 247 (LE -photos). Southern Vietnam, Gia Lai province [prov. Qui Nhon], An Khe, 400-500 m, epiphyte with milky latex, 1930-8-9, E. Poilane 17956 (P [P00700443, P00700444]). Southern Vietnam, Kon Tum province, Ngoc Linh Mountains, primary and secondary evergreen broad-leaved mountain forest, 2015, N. V. Canh s. n. (LE - photos). Southern Vietnam, Ninh Thuan province, Ninh Hai district, Vinh Hai municipality, E slopes on Nui Chua mountains, $11^{\circ} 43^{\prime} 52^{\prime \prime} \mathrm{N}, 109^{\circ} 08^{\prime} 35^{\prime \prime} \mathrm{E}$ at $800-950$ $\mathrm{m}$, primary evergreen closed dry forest on rocky mountain slopes composed with granite, epiphyte, not common, 31 March 2004, J. Regalado et al., HLF 4456 (LE - photo). Southern Vietnam, Ninh Thuan province, Phanrang, Cana, $700-800 \mathrm{~m}$, epiphyte with milky latex, 1925-10-16, E. Poilane 12316 (P [P00700494]), 1925-10-28, E. Poilane 12516 (P [P00700495]). Southern Vietnam, Ninh Thuan province, Phanrang, Ca-na, $300 \mathrm{~m}, 1923-11-9$, E. Poilane 8505 (P [P00700493]). Southern Vietnam, Cochinchina ad ontem Knewanh, 1870-9, L. Pierre s. n. (P [P00700502]).

\section{Hoya nummularioides Costantin,}

1912, Fl. Indo-Chine 4: 129; Pham H.H., 2003, Ill. Fl. Vietnam 2: 750, fig. 7000.

Fig. $12 \mathrm{~F}-\mathrm{H}$.

Described from S. Cambodia and Laos ("Cambodge: Kompong-track (Geoffray). - Laos: Bassac, Kong (Thorel)"). Lectotype ("Kampong Trach,
Kampot province, Cambodia, C. Geoffray 485, 1905-10-3, ...") - P [P00639776], isolectotype - P [P00639777]; lectotype here designated.

Vernacular name in Vietnam. Cẩm cù num.

Habitat, phenology and conservation status. Epiphytic creeping vine to $2 \mathrm{~m}$ long with white latex. Dry dipterocarp forests and woodlands, on thin ferralitic grey to brown rocky soils, $200 \mathrm{~m}$. Fl. October - November. Locally common. Estimated IUCN Red List status - DD.

Distribution. Cambodia (Kampot province), Laos (Savannakhet, Bassac and Sainyabuli provinces), Vietnam (Dak Lak province). Thailand.

Notes. The lectotype chosen by D. H. Kent in November 1988 (in sched.) had been never published. It is confirmed and validated here. This species is here newly reported for the flora of Vietnam.

Studied specimens. Cambodia - Laos, Expédition du Me-Kong, Paklai, Kouy, Bassac, Laos, C. Thorel 2318, 1866/1868 (P [P00639778, P00639779, P00639780, P00639781, P00639782, P00639783]). Southern Vietnam, Dak Lak province, Buon Don district, Krong $\mathrm{Na}$ municipality, Yok Don national park, $13^{\circ} 04^{\prime} \mathrm{N}, 107^{\circ} 37^{\prime} \mathrm{E}$, dry dipterocarp forest and woodland, on thin ferralitic grey to brown rocky soils at $200 \mathrm{~m}$, epiphytic creeping vine with white latex grow in humus pocket trees, to $2 \mathrm{~m}$ long on Dipterocarpus spp., locally common, herbarium specimen prepared from cultivated plant collected from the wild, 18 November 2015, N. V. Canh PVT DL 014-2015 (LE, HN).

Hoya nutans Aver. et V. T. Pham, sp. nov.

Fig. 13.

Type ("16 July 2016, L. Averyanov, T. Maisak, CPC 1592e /11531") - LE (holotype, isotypes), herbarium specimen prepared from cultivated plant collected in N. Vietnam ("N. Vietnam, Hoa Binh province, Lac Son district, Tu Do municipality, Mon village, around point $20^{\circ} 25^{\prime} 29^{\prime \prime} \mathrm{N}, 105^{\circ} 19^{\prime} 36^{\prime \prime} \mathrm{E}$, primary broad-leaved forest on steep rocky slopes of remnant mountain composed with solid crystalline highly eroded limestone at elevation 500-700 $\mathrm{m}$ a. s. 1., semi-woody vine, occasional, 25 March 2011, N. Q. Hieu, L. Averyanov, N. T. Hiep, P. K. Loc, P. V. The, N. T. Vinh, T. B. Ngan, N. Tap, D. D. Dao, V. T. Ha, T. Maisak, L. Osinovetz, CPC 1592e"). Plate: digital Vietnamese flora 0258/CPC 1592e/11531, fig. 13.

Etymology. Species name refers nutant flowers, placed on long slender weak pedicel.

Vernacular name in Vietnam. Cẩm cù bon giả.

Description. Epiphytic vine with clear sap to $5 \mathrm{~m}$ long. Stem dull pale olive-green, later dull 
brownish-grey or light grey, relatively thin, rather straight, terete, (1.2)1.5-2(2.5) $\mathrm{mm}$ in diam., sparsely shortly hairy when young, glabrous when mature, with sparse adventitious roots and leafy throughout; internodes (8)10-18(20) cm long. Leaves petiolate; petiole usually curved or slightly twisted, (0.6)1-2.8(3.2) cm long, (2.5)3-3.5(4) mm in diam., almost terete, dull green to olive-green, sometime with dirty purple tinge, shortly sparsely hairy; leaf blade not much fleshy, coriaceous, ovate, (8)9-15(16) cm long, (4.5)5-9(11) cm wide, almost flat to slightly curved, cordate, round, or sometime cuneate at the base, shortly acuminate, uniform green above, with distinct dark green arching nerves, light green to whitish below, abaxial surface with stiff sparse hairs when young (can be seen by naked eye) broadening and blackish at the base, adaxially glabrous, old leaves entirely glabrous, with distinct midvein and 4-6 pairs of irregularly arching lateral veins adaxially, arising at $40^{\circ}-60^{\circ}$, abaxial surface with prominent midrib, and hardly visible lateral veins. Inflorescence an extra-axillary umbel, arising often from old leafless apical part of stem, with (14)16-20(25) flowers; peduncle notably short, stout, cylindrical, (0.3)0.5-2.5(3) cm long, (1)1.2-1.6(2) $\mathrm{mm}$ in diam., green, dull olive-green or green-grey, sparsely shortly hairy to subglabrous, rachis capitate to shortly cylindrical, (4.5)5-8(10) $\mathrm{mm}$ long, 2.5-3 $\mathrm{mm}$ in diam., with several irregular whorls of small persistent triangular floral bracts; pedicels white to light reddish-pink, lightening to the apex, cylindrical, slender, weak, nutant, (2.8)3$3.4(3.6) \mathrm{cm}$ long, (0.7)0.8-1(1.1) $\mathrm{mm}$ in diam., glabrous. Flowers with weak sweet fragrance, widely opening, (1.5)1.6-1.7(1.8) $\mathrm{cm}$ in diam. Calyx light reddish-brown, almost flat, glabrous, of 5 sepals almost free at the base, sepals, narrowly triangular, obtuse to subacute, (2)2.1-2.2(2.3) mm long, (0.9)1(1.1) $\mathrm{mm}$ wide near base, sparsely hairy outside, glabrous inside. Corolla pentagonal, shallowly campanulate, fleshy, pure white above, white with light pink tint below, (1.5)1.6-1.7(1.8) $\mathrm{cm}$ in diam.; densely hirsute adaxially, glabrous and smooth abaxially, tube 6-7 mm long, lobes 4.4-5.5 $\mathrm{mm}$ long, 7-9 $\mathrm{mm}$ broad, with slightly recurved margins, and recurved tip. Corona glossy, yellowishwhite, of 5 lobes, (2)2.2-2.4(2.6) mm tall, (8.2)8.5$8.8(9) \mathrm{mm}$ in diam., grooved between lobes; lobes ovoid pyramidal in outline, slightly concave above, (4.5)4.6-4.8(5) $\mathrm{mm}$ long including adnate part, free part 1.9-2 mm, and (1.9)2-2.2(2.4) $\mathrm{mm}$ wide, at the base rhomboid elliptic, with basal revolute margins; outer process (when fresh) broadly conoid, obtuse, slightly erect, pale yellow; inner process conoid, acute, slightly erect, (0.7)0.8-0.9(1) mm long, straight, almost meeting above gynostegium. Style head discoid oblate, (0.8)0.9-1.1(1.2) mm tall, (2.3)2.4-2.5(2.6) in diam.; anther appendages white, scarious. Pollinarium: corpusculum narrowly rhomboid, angled, 0.2-0.25 mm long, 0.1-0.15 $\mathrm{mm}$ wide; translators very short, about $0.05 \mathrm{~mm}$ long; pollinia oblong, (0.6)0.6-0.7(0.8) $\mathrm{mm}$ long, 0.1-0.15 mm wide, bright yellow; germinating crest rather indistinct, light yellowish-hyaline, extending from translator to pollinium apex. Carpels 2, free, half bottle-shaped, densely connivent each other, $1.8-2 \mathrm{~mm}$ tall, $0.8-0.9 \mathrm{~mm}$ wide at the base, articulated apically to white, oblate stigma head, (0.6)0.7-0.8(0.9) $\mathrm{mm}$ tall, (1.8)2-2.2(2.3) $\mathrm{mm}$ in diam.

Habitat, phenology and conservation status. Primary broad-leaved forests on rocky karstic limestone, commonly on steep slopes near mountaintops, 500-700 m. Fl. July. Occasional. Estimated IUCN Red List status - DD.

Distribution. Vietnam (Hoa Binh province). Endemic.

Notes. This species most closely resembles $H$. bonii, $H$. carnosa and $H$. fungii, but can be distinguished by the presence of stiff sparse hairs clearly visible by naked eye and blackish color at the abaxial base of the lamina (the three other species have either glabrous leaves or fine pubescence visible under magnification only), campanulate flowers with pentagonal corolla (rotate corolla in the three other species) and corona lobes yellowish-white, ovoidpyramidal with outer process obtuse (vs. pinkish, acute or acuminate corona lobes in the three other species).

\section{Hoya oblongacutifolia Costantin,}

1912, Fl. Indo-Chine 4: 139; Tran T.B., 2005, Checklist Pl. Sp. Vietnam 3: 67.

Fig. 12I, 14A-C.

Described from southern Vietnam ("Mt. Deonba, Tay-ninh, Pierre"). Lectotype ("Austro-Cochinchina, in montibus Deon Ba ad Tay Ninh", Apr 1866, Pierre 4528") - P [P00639820], isolectotypes - P [P00639821, P04025652, P00639822, P05207933]; lectotype here designated.

$=$ Hoya graveolens Kerr, 1939, Bull. Misc. Inform. Kew. 8: 461; Rodda et al., 2012, New Hoya Vietnam: 4, syn. nov.

Described from central Thailand. Lectotype ("Thailand, Sriracha, 15 May 1920, Kerr 4245") - BM [BM001014260], isolectotypes - K 


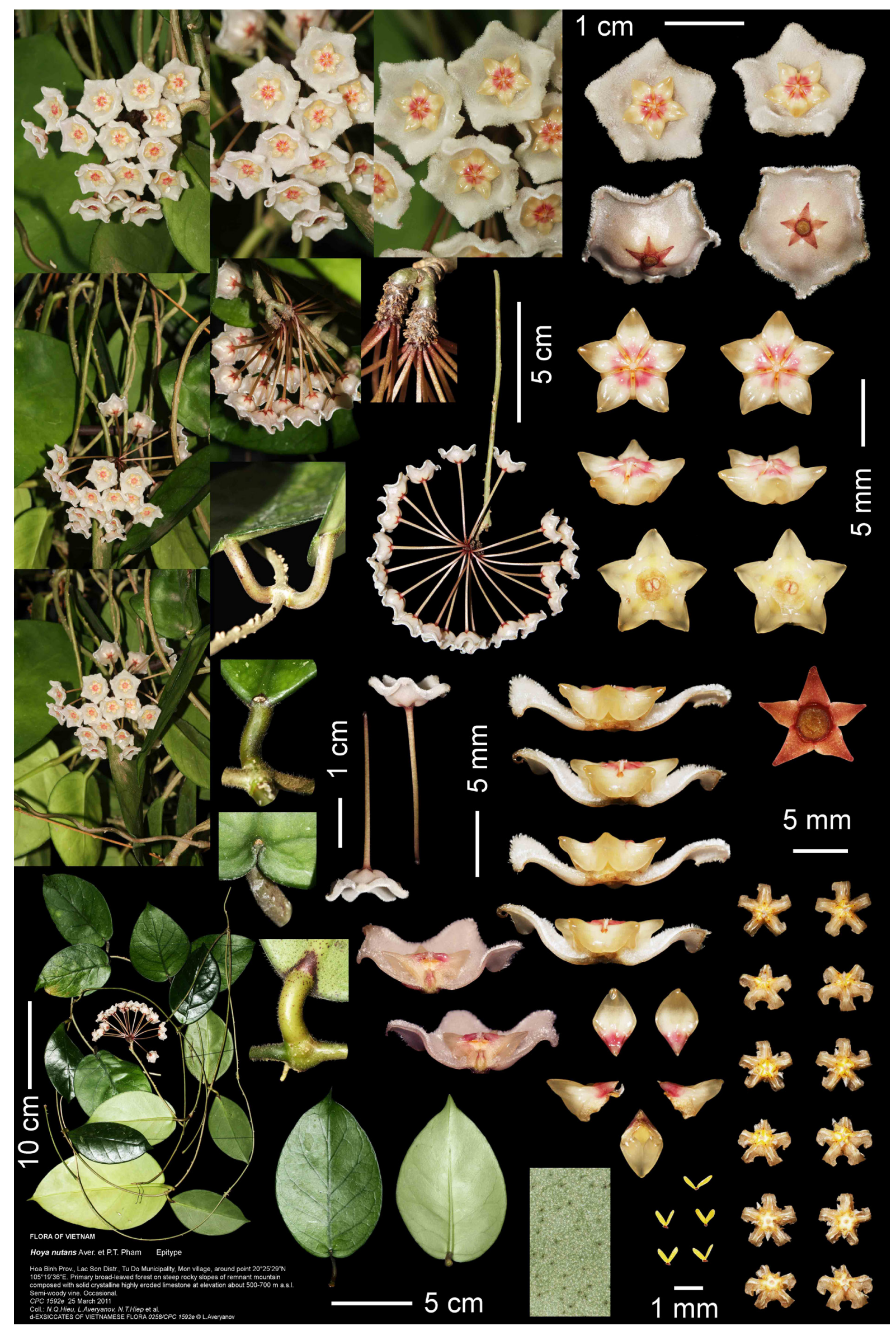

Fig. 13. Hoya nutans V. T. Pham et Aver. Digital Vietnamese flora 0258/CPC 1592e. Photos, correction and design by L. Averyanov and T. Maisak. 


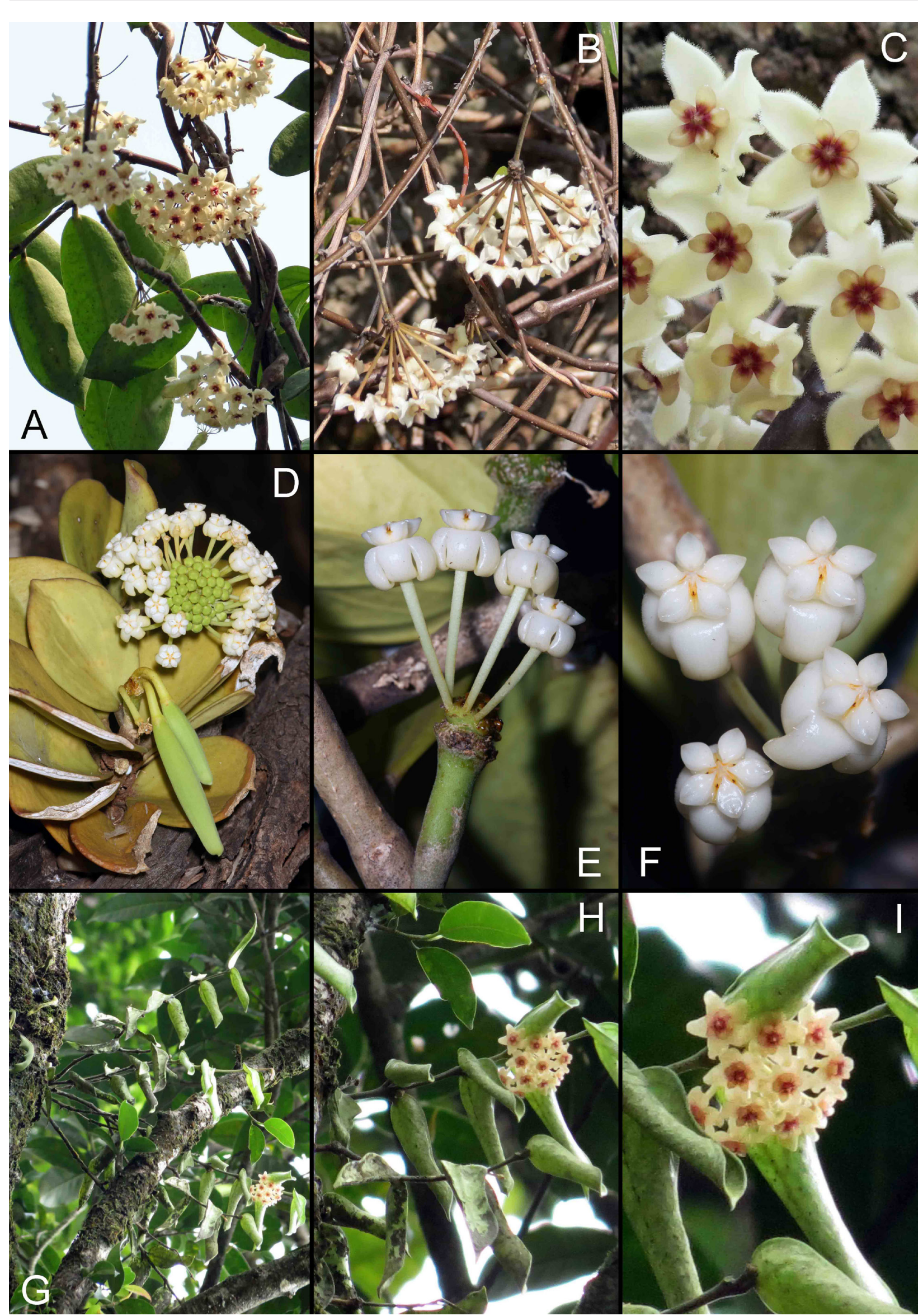

Fig. 14. Hoya oblongacutifolia Costantin: A-C (2014, N. V. Canh, AL 241, photos of N. V. Canh). H. pachyclada Kerr: D-F (HLF 7241, photos of L. Averyanov). H. pandurata Tsiang: G-I (N. V. Canh s. n., 2016, AL 236, photos of N. V. Canh). 
[K000215162], P [P00700505]; designated by Rodda et al. (2012, p. 4).

Habitat, phenology and conservation status. Lithophytic and epiphytic semi-woody vine to 8 $\mathrm{m}$ long. Primary and secondary evergreen, broadleaved lowland forests on any kind of soils, often on low karstic limestone hills, 50-300 m. Fl. April, January - February. Not common. Estimated IUCN Red List status - DD.

Distribution. Vietnam (Dak Lak and Kien Giang provinces). Thailand.

Notes. Original material of $H$. oblongacutifolia was only indicated as "Mt. Deon-ba, Tay-ninh, Pierre". Five duplicates have been found at P. The one with barcode [P00639820] is fertile and well preserved and is therefore here designated as lectotype. H. graveolens Kerr (1939) was reported as a new record from Vietnam in 2013 (Rodda et al., 2013) and only subsequent examination of original material of $H$. oblongacutifolia allowed to clarify that the two names should be applied to the same taxon.

Studied specimens. Southern Vietnam, Dak Lak province, Ea H'leo district, primary and secondary evergreen, broad-leaved lowland forest on alluvial soils, 2014, N. V. Canh, AL 241 (LE - photos). Southern Vietnam, Kien Giang province, Kien Luong district, Binh An commune, $50 \mathrm{~m}, 10^{\circ} 08^{\prime} 23^{\prime} \mathrm{N}, 104^{\circ} 38^{\prime} 27^{\prime}$ 'E, 9 April 2009, Ly, 521 (HN, P, SING, VNM). Southern Vietnam, Kien Giang province, Hang Tien Karst Hill, 45 m, 10¹1'04'”N, 104³5'41'”, 4 May 2007, Ly et al., 61 (VNM); Mo So (Bai Voi) Karst Hill, 47 m, $10^{\circ} 13$ '21'N, 104³6'54'E, 16 April 2008, Ly et al., 125 (VNM); Ba Tai Karst Hill, 99 m, 10¹0'17’N, 104³6'07’'E, 12 April 2008, Ly et al., 185 (VNM).

\section{Hoya pachyclada Kerr,}

1939, Bull. Misc. Inform. Kew. 8: 462.

Fig. 14D-F.

Described from Thailand ("Siam, Kawnken, $\mathrm{Pu}$ Wieng, circiter $300 \mathrm{~m}$., on trees in deciduous Pentacme-Shorea forest, Kerr 20007'). Lectotype ("Siam, Kaun Ken, Pu Wieng, 300 m, 1931-2-6, A.F.G. Kerr 20007") - BM [BM001014253], isolectotypes - BK [BK257734], K [K000545616], $\mathrm{P}$ [P00700508]; lectotype here designated.

Vernacular name in Vietnam. Cẩm cù khô.

Habitat, phenology and conservation status. Humus epiphytic or occasionally lithophytic undershrub or semi-woody vine to $4 \mathrm{~m}$ long. Primary and secondary broad-leaved open evergreen and deciduous dry lowland forests and woodlands on any kind of mother rocks, often on thin, ferralitic soils,
20-220 m. Fl. March - April. Locally common. Estimated IUCN Red List status - DD.

Distribution. Cambodia (Koh Kong and Pursat provinces), Laos, Vietnam (Dak Lak and Thua Thien - Hue provinces). Thailand.

Notes. This is the first record of the species for Vietnam. It was observed in visited localities as a quite common plant in dry lowland primary and secondary forests. It is also not rare in Cambodia and Laos. The color of the corolla is variable from almost white to purple even within one population (based on observation in Thailand and Vietnam).

Studied specimens. Cambodia, eastern part of Cardamom Mountains, foothills of Phnom Aural Mountain at $19 \mathrm{~m}, 11^{\circ} 54^{\prime} 457^{\prime \prime} \mathrm{N}, 104^{\circ} 07^{\prime} 257^{\prime \prime} \mathrm{E}, 25$ November 2012, T. Maisak et al., 945 (LE). Cambodia, Kake, 2-1976, Harmand 449 (P [P05207917, P05207918, P05207916]). Cambodia, Dangrek, Ta Trau, Stung Treng, epiphyte, 13-3-1928 M. Poilane 14906 ( $\mathrm{P}$ [P04551121]). Cambodia, Pursat, Ko Virk, Kang Chon, 9-5-1928, Poilane s. n. (P [P05207915]). Southern Vietnam, Dak Lak province, Buon Don district, Krong Na municipality, Yok Don national Park, Yok Don Ridge, 12 $51^{\prime} 36^{\prime \prime} \mathrm{N}$, $107^{\circ} 42^{\prime} 22^{\prime \prime} \mathrm{E}$, dry open semi-deciduous dipterocarp forest with bamboo on thin ferralitic soil at 180-220 m, creeping epiphytic vine $0.5-1 \mathrm{~m}$ long, flowers white to light yellowish, common, 20 March 2008, N. T. Hiep et al., HLF 7241 (HN, LE, MO). Southern Vietnam, Dak Lak province, Buon Don district, Krong Na municipality, Yok Don national park, $13^{\circ} 04^{\prime} 13^{\prime \prime} \mathrm{N}, 107^{\circ} 37^{\prime} 57^{\prime \prime} \mathrm{E}$, dry dipterocarp forest and woodland, on thin ferralitic grey to brown rocky soils at about $200 \mathrm{~m}$, epiphytic vine 1-3 m long, flowers white to yellowish, very common, 27 March 2008, N. T. Hiep et al., HLF 7394 (HN, MO). Southern Vietnam, Thua Thien - Hue province, Nam Dong district, Thuong Lo municipality, along Cha Mang stream, 16 $07^{\prime} 46^{\prime \prime} \mathrm{N}, 107^{\circ} 44^{\prime} 24^{\prime \prime} \mathrm{E}$, remnants of primary evergreen broad-leaved lowland forest on very steep hill slopes and rocky river valley composed with stratified shale and sandstone at 50-70 m, creeping epiphytic and lithophytic vine 2-4 m long on tall trees, flowers white, center reddish, occasional, 6 April 2007, L. Averyanov et al., HAL 10949 (HN, LE, MO).

Hoya pandurata Tsiang,

1939, Sunyatsenia 4: 125; Tsiang, Li, 1974, Acta Phytotax. Sin. 12, 1: 125; Li et al., 1995, Fl. China 16: 235; Kidyoo, Thaithong, 2007, Nat. Hist. Journ. Chulalongkorn Univ. 7, 1: 47.

Fig. 14G-I. 
Described from southern China. Type ("China, Yunnan, Sze-Mao, A. Henry 12258”) - NY [NY00318645], isotypes - A [A00076422], E [E00275183], K [K000873049], MO [MO2107362], US [US00048552].

Habitat, phenology and conservation status. Humus epiphytic undershrub with spreading, sparsely branched shoots up to $1 \mathrm{~m}$ long. Primary and secondary broad-leaved semideciduous and evergreen dry and humid forests on any kind of mother rocks, often on exposed mountaintops, 800-1200 m. Fl. December - January. Very rare. Estimated IUCN Red List status - DD.

Distribution. Laos (Phongsali province), Vietnam (Bac Kan province). S China (Yunnan), Thailand.

Notes. The location cited below presents new records for the flora of Laos and Vietnam.

Studied specimens. Northern Laos, Phongsali province, Boun Neua, 1200 m, semideciduous oak forest mixed with bamboo on ridge top, cultivated at the Singapore Botanic Gardens, vouchered as M. Rodda MR735 on 18 September 2014 (SING). Northern Vietnam, Bac Kan province, Cho Don district, primary humid evergreen broad-leaved forest, 800-900 m, 2016, N. V. Canh s. n., AL 236 (LE).

\section{Hoya parviflora Wight,}

1834, Contrib. Bot. India: 37.

Fig. 15A-C.

Described from S. Myanmar ("Mawlamyine"). Type ("Maulmyne, Myanmar, N. Wallich 33a, 1821-1829”) - E [E00179569].

Vernacular name in Vietnam. Cẩm cù lá nhỏ.

Habitat, phenology and conservation status. Epiphytic creeping vine to $2 \mathrm{~m}$ long. Primary and secondary evergreen broad-leaved forests, commonly in humid places along streams, $500-1000 \mathrm{~m}$. F1. June - August. Not common. Estimated IUCN Red List status - VU.

Distribution. Vietnam (Quang Ngai province). Sri Lanka, Myanmar, Malaysia.

Notes. The location cited below presents a new record for the flora of Vietnam.

Studied specimens. Central Vietnam, Quang Ngai province without exact locality, 6 June 2016, N. V. Canh, cultivated in private garden in Buon Ma Thuot City, herbarium specimen prepared in 12 October 2016, N. V. Canh, L. Averyanov, T. Maisak, AL 238 (LE). Central Vietnam, Quang Ngai province, Tay Tra district, $15^{\circ} 07^{\prime} 38.2^{\prime \prime} \mathrm{N}, 108^{\circ} 17^{\prime} 57.5^{\prime \prime} \mathrm{E}$, 500-1000 m, primary and secondary evergreen broad-leaved forest, epiphytic vine to $1 \mathrm{~m}$ long in humid place along stream, not common, herbarium specimen prepared from cultivated plant collected from the wild, 25 July 2016, N. V. Canh, PVT DL 015-2016 (HN).

Hoya polyneura Hook. f.,

1883, Fl. Brit. India 4: 54; Li et al., 1995, Fl. China 16: 233.

Fig. 15D-G.

Described from NE India ("Sikkim Himalaya"). Type ("Herb. Griffith, alt. 3-5000 ft., J. D. H., Clarke.") - K.

Habitat, phenology and conservation status. Humus epiphytic undershrub with spreading, sparsely branching shoots to $1 \mathrm{~m}$ long. Primary and secondary broad-leaved evergreen dry forests on shale and sandstone mountains, commonly on tall trees along ridge edges, 1700-1900 m. Fl. May June. Rare. Estimated IUCN Red List status - DD.

Distribution. Laos (Xiangkhouang province). Bhutan, NE India, Myanmar, SW China (Xizang, NW Yunnan).

Notes. The collection of $H$. polyneura in Laos slightly extends its distribution area to the south, as the species was already known to occur in neighbouring Yunnan. Flowers of cultivated plants have light sweet fragrance.

Studied specimens. North-eastern Laos, Xiangkhouang province, Peak district, Oran village, around point $19^{\circ} 38^{\prime} 53^{\prime \prime} \mathrm{N}, 103^{\circ} 23^{\prime} 12^{\prime \prime} \mathrm{E}$, primary and secondary broad-leaved evergreen dry forest on shale sandstone slopes and along ridge edge, 1750-1850 m, epiphytic undershrub with shoots to $1 \mathrm{~m}$ long on tall mossy tree, rare, 2 April 2015, N. T. Hiep et al., LA-VN 906 (FOF, HNL, LE).

Hoya revolubilis Tsiang et $\mathrm{P}$. $\mathrm{T}$. Li,

1974, Acta Phytotax. Sin. 12, 1: 124; Li et al., 1995, Fl. China 16: 231.

Fig. 16.

Described from southern China. Type ("China, Yunnan, Aug 1912, G. Forrest 9108”) - A [A00076423], isotypes - E [E00275182], IBSC [IBSC 0005697].

Habitat, phenology and conservation status. Epiphytic creeping vine to $6 \mathrm{~m}$ long. Primary and secondary evergreen broad-leaved mountain forests. Fl. October - November. Rare. Estimated IUCN Red List status - DD.

Distribution. Vietnam (Lai Chau province). Myanmar, S China (Guangxi, Yunnan).

Notes. $H$. revolubilis, together with other species in the $H$. carnosa group, is one of the few species 


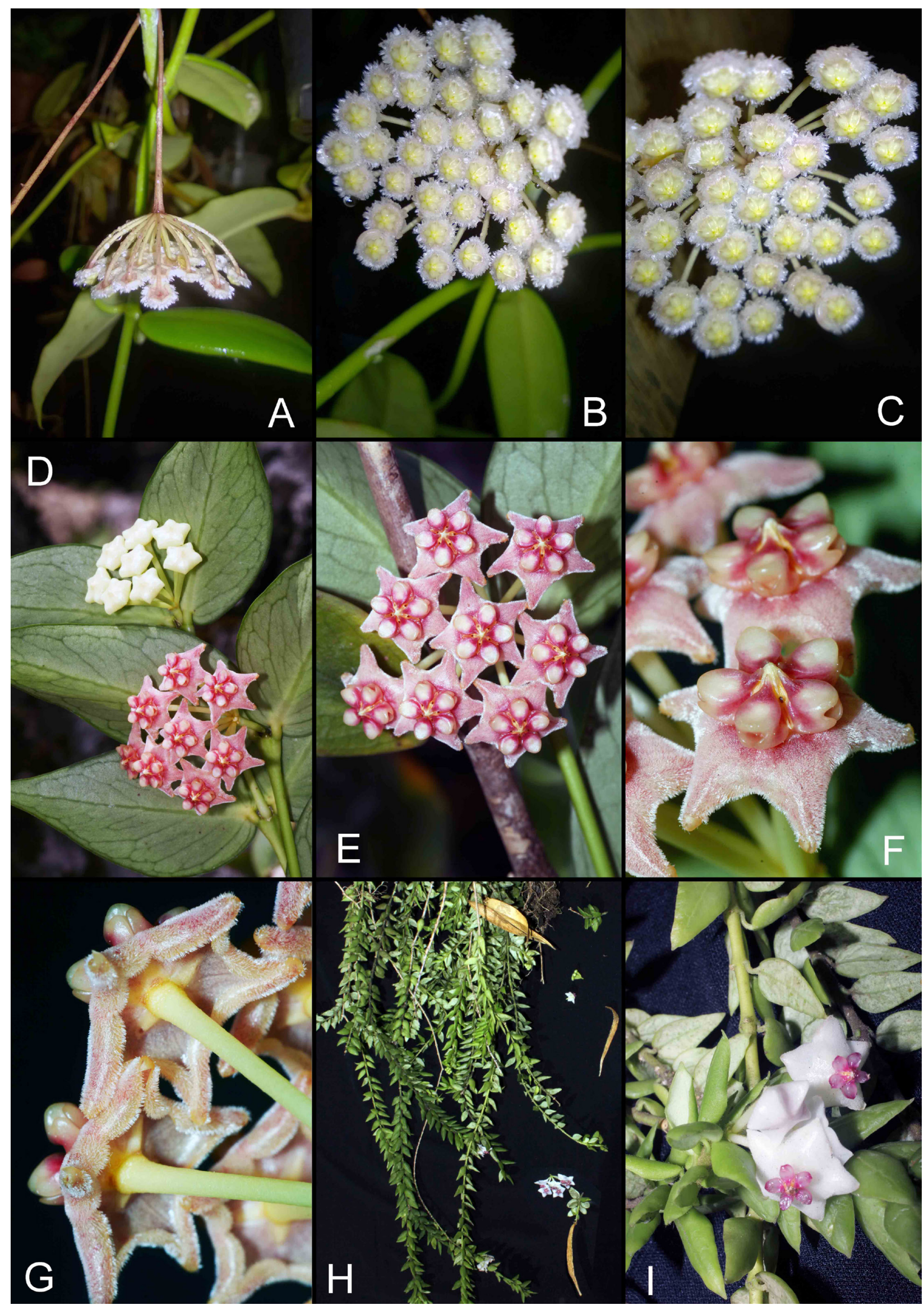

Fig. 15. Hoya parviflora Wight - A-C (PVT DL 015-2016, photos of N. V. Canh). H. polyneura Hook. f.: D-G (LAVN 906a, photos of L. Averyanov). H. vaccinioides Hook. f.: H, I (7 May 2016, N. P. Tam s. n., photos of N. P. Tam). 


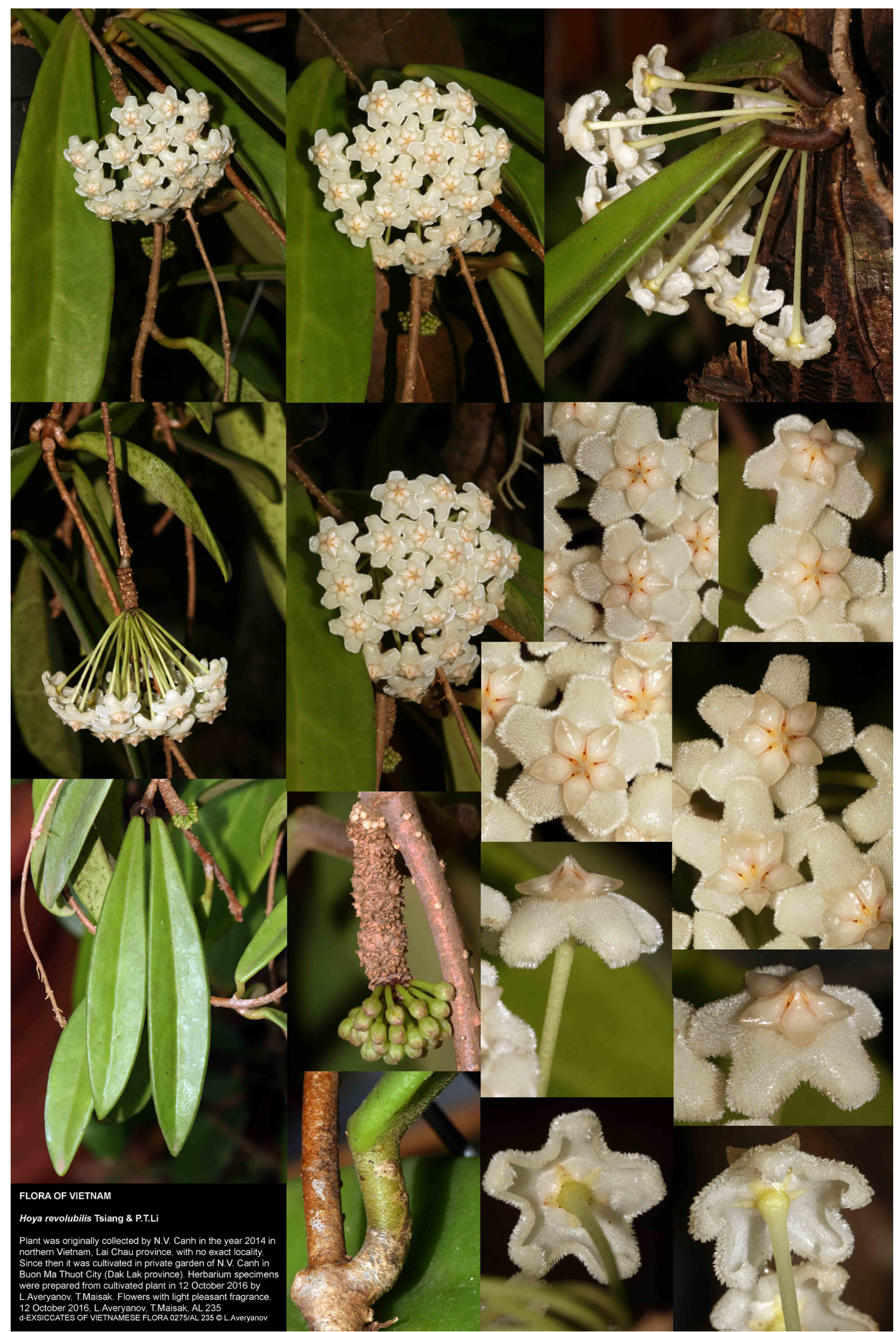

Fig. 16. Hoya revolubilis Tsiang et P. T. Li. Digital Vietnamese flora 0275/AL 235. Photos, correction and design by L. Averyanov and T. Maisak. 
in the genus with uncolored latex. It is most similar to $H$. salweenica Tsiang et P. T. Li (1974) found in China, but it can be separated because of its revolute leaf margins (when dry) and cuneate lamina base. $H$. salweenica instead has flat lamina margins and round or obtuse lamina base.

Studied specimens. Northern Vietnam, Lai Chau province, with no exact locality, 2014, N. V. Canh, cultivated in private garden in Buon Ma Thuot City, herbarium specimens prepared in 12 October 2016 by N. V. Canh, L. Averyanov, T. Maisak, AL 235, flowers white, with light pleasant fragrance (LE).

Hoya uniflora Aver. et V. T. Pham, sp. nov. Fig. 17.

Type ("NE. Laos, Xiangkhouang province, Peak district, Khoang village, $\mathrm{Pa}$ Khao mt., around point $19^{\circ} 33^{\prime} 02.2^{\prime \prime} \mathrm{N}, 103^{\circ} 39^{\prime} 56.3^{\prime \prime} \mathrm{E}, 3$ April 2015, N. T. Hiep, L. Averyanov, N. S. Khang, N. Q. Hieu, T. Maisak, Pheng Phengsintham, LA-VN 961") LE (holotype), LE, FOF, HNL (isotypes). Plate: digital Vietnamese flora 0255/LA-VN 961, fig. 17.

Etymology. The species name refers to the obligatory uniflorous inflorescence.

Description. Lithophytic and occasionally epiphytic vine with milky latex to $35 \mathrm{~cm}$ long. Stem green to grey, slender, rather herbaceous, flexuose, terete, (0.8)0.9-1(1.1) $\mathrm{mm}$ in diam., densely shortly hairy, creeping by sparse adventitious roots; leafy throughout; internodes (1.5)2-4(5) cm long. Leaves petiolate; petiole straight (in young leaves) to strongly curved, (3)4-8(10) mm long, (0.7)0.80.9 (1) $\mathrm{mm}$ in diam., terete, green, sparsely hairy; leaf blade glabrous, very rigid and fleshy, elliptic, narrowly ovate to broadly ovate or almost orbicular, (1.2)1.5-2(2.5) cm long, (0.8)0.9-1.4(1.6) cm wide, straight or slightly curved, cuneate to roundish at base, obtuse, round or notched at apex, with no visible nerves; adaxial side often rough, glossy green, with distinct longitudinal fold; abaxial side light greenish to almost white, with glossy green or silvery-green broad band along midrib. Inflorescence 1-flowered; peduncle an extra-axillary, cylindrical, green, very short, rather stout, (3)4-4.5(5) mm long, twice thicker than stem, densely hairy; pedicels glabrous, glossy light green to white, cylindrical, slender, (2.8)3-3.2(3.5) cm long, (0.8)1-1.2 mm in diam. Flowers pendulous, sweet fragrant. Calyx (3.2)3.4-3.6(3.8) $\mathrm{mm}$ in diam., flat to slightly convex, pentagonal, glabrous, of 5 sepals fused for more than half of their length, sepals greenish to pale light olive-brownish, broadly triangular, acute, their free parts (0.4)0.5(0.6) mm long, (1.2)1.4(1.6) mm wide. Corolla of 5 petals, flat, fleshy, pure white, (2.6) $2.8-3(3.2) \mathrm{cm}$ in diam.; tube $7-8 \mathrm{~mm}$ long, petals almost straight spreading, oblong triangular, (8.5)8-9(10) $\mathrm{mm}$ long, 8-9 $\mathrm{mm}$ wide near the base, finely densely hirsute adaxially, glabrous and finely rough abaxially, with recurved margins; at apex petals obtuse and unguiculate, with apiculate recurved tip (0.7)0.8-0.9(1) $\mathrm{mm}$ long and wide. Corona glossy white, of 5 segments, (3.4)3.6-3.8(4) $\mathrm{mm}$ tall, (12)12.5-13.5(14) $\mathrm{mm}$ in diam., grooved between lobes; lobes ovoid in outline, convex above, (5)6-6.5(7) mm long, (3)3.2-3.4(3.6) mm wide, at the base broadly elliptic, outer process with obtuse outer angle, inner process attenuate into straight, narrowly conoid acute tip (1.4)1.5-1.8(2) mm long, as long as style head apex or slightly shorter. Style head discoid oblate (rhomboid in sagittal section), 1.8-2 mm tall, 2.9-3.2 mm in diam.; anther caps white, proximally yellowish; corpuscula chestnutpurple. Pollinarium: corpusculum narrowly rhomboid, angled, 0.6-0.7 mm long, 0.15-0.2 mm wide; translators very short, $0.05-0.1 \mathrm{~mm}$ long; pollinia oblong, (0.8)0.9-1(1.1) $\mathrm{mm}$ long, 0.3-0.35 mm wide, bright yellow; germination crest distinct, yellowish-hyaline, extending from translator to pollinium apex. Carpels 2, free, half-bottle shaped, densely connivent each other, $1.5-1.6 \mathrm{~mm}$ tall, $0.7-0.8 \mathrm{~mm}$ in diam., articulated apically to white, oblate stigma head apex, $1.6-1.7 \mathrm{~mm}$ tall, $2.8-3 \mathrm{~mm}$ in diam.

Habitat, phenology and conservation status. Creeping tiny herbaceous lithophytic and occasionally epiphytic vine to $35 \mathrm{~cm}$ long. Primary and secondary broad-leaved evergreen dry forests on rocky karstic limestone, commonly on open mossy rocks and cliffs near mountaintops, 1200-1450 m. Fl. April - June. Locally common. Estimated IUCN Red List status - DD.

Distribution. Laos (Xiangkhouang province). Endemic.

Notes. The new species is rather unusual in the genus because of its obligatory 1-flowered inflorescences. No other species from Indochina have this peculiar feature that is otherwise observed in mainland Asia only in $H$. mappigera Rodda et Simonsson Juhonewe (2012b) and $H$. wallichii (Wight) C. M. Burton (Burton, 1996; Rodda et al., 2016) that however have large campanulate corollas, and in a few species from Papua.

On its plant habit and floral morphology, it may be solely compared with $H$. serpens Hook. f. (Hooker, 1883), known from NE India. However, beside 1-flowered inflorescence $H$. uniflora differs from H. serpens in smooth (not papillose) petiolate (not 


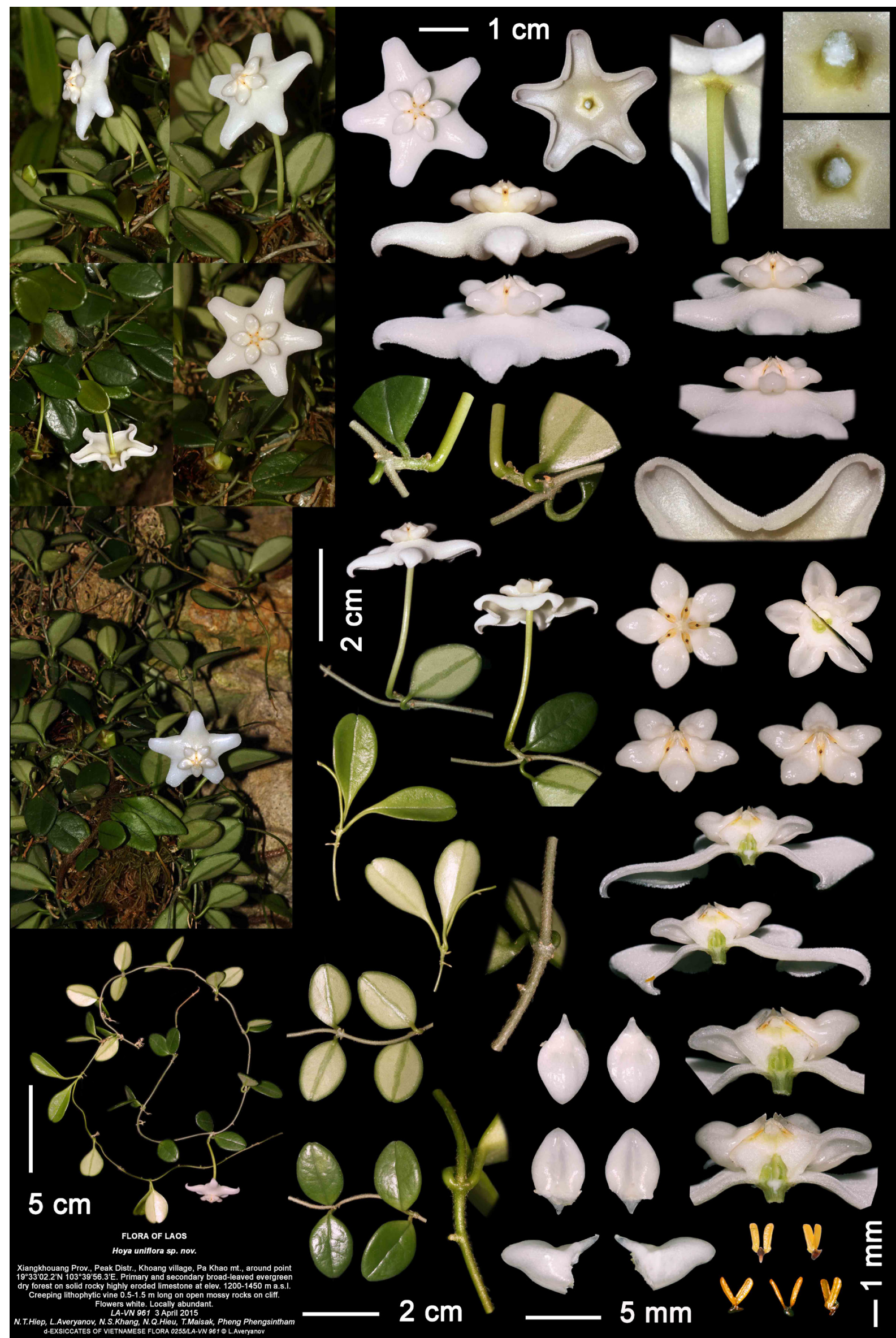

Fig. 17. Hoya uniflora Aver. et V. T. Pham. Digital Vietnamese flora 0255/LA-VN 961. Photos, correction and design by L. Averyanov and T. Maisak. 
nearly sessile) leaves, very short peduncle (much less than $3 \mathrm{~cm}$ ), glabrous long pedicels (longer than $2 \mathrm{~cm}$, with neither hairs, no lenticular markings) and twice larger, pure white flowers (neither greenish, yellowish or pink). The leaves almost white below with green stripe along midrib are also very characteristic, which well distinguishes the new species even in sterile state. H. uniflora allies to type section, but exhibits certainly isolated position among members of this section. Species of superficially similar habit, namely $-H$. nummularia Hook. f. (Hooker, 1883 ) from NE. India and $H$. nummularioides Costantin (1912) known in Laos and Cambodia, as well as $H$. retusa Dalzell (1852) with occasionally solitary flowers (occurring in India) have hardly close relation to discovered species.

Hoya vaccinioides Hook. f.,

1883, Fl. Brit. India 4: 56; Newman et al., 2007, Checklist Vasc. Pl. Lao PDR: 71.

Fig. 15H, I, 18A.

Described from NE India. Lectotype ("India, Arunachal Pradesh, Mishmee mountains, by the Thumat River. W. Griffith 3799”)-K [K000873082], lectotype here designated.

Vernacular name in Vietnam. Cẩm cù hoa tán nhỏ.

Habitat, phenology and conservation status. Humus epiphyte and lithophyte with pendulous sparsely branching shoots to $0.5 \mathrm{~m}$ long. Primary broad-leaved evergreen humid forests on silicate mountains, 1200-1500 m. Fl. April - May. Very rare. Estimated IUCN Red List status - EN.

Distribution. Laos (Khammouan province), Vietnam (Lam Dong province). Thailand.

Notes. Based on the habit and leaf shape this is likely H. vaccinioides Hook. f. (Hooker, 1883), a species that was however described based on fruiting material only. This is the first record of this rare species for the flora of Vietnam. More collections are necessary to work out if the similar species, H. engleriana Hosseus (1907) distributed in NE India, Nepal and N Thailand, $H$. dickasoniana P. T. Li (Li, 1994) from Myanmar, and H. weebella Kloppenb. (Kloppenburg, 2005), described based on cultivated material without better specified wild origin shall be considered synonyms of $H$. vaccinioides. The Vietnamese collections are characterized by ovate leaves arranged often by three at a node and densely hirsute stem, petioles, peduncle, pedicel and calyx. The pedicel densely hairy with long stellate hairs pointing toward the calyx looks unique for the genus. The species is rare, highly endangered element of fast decreasing primary woods and desire status of endangered species. The collecting as ornamental plant due to market demands is additional important factor of its fast extinction in nature.

Studied specimens. Southern Vietnam, Lam Dong province, Lam Ha district, primary broadleaved evergreen humid mountain forest, epiphyte with pendulous shoots to $1 \mathrm{~m}$ long, 7 May 2016, N. P. Tam s. n., AL 269 (LE, LE - photo). Southern Vietnam, Lam Dong province, Bidoup Mountains, May 2016, N. V. Canh, herbarium specimen prepared from specimen cultivated in private garden in Buon Ma Thuot City in 12 October 2016 by N. V. Canh, L. Averyanov, T. Maisak, AL 237 (LE).

Hoya verticillata (Vahl) G. Don,

1838, Gen. Hist. 4: 128; Newman et al., 2007, Checklist Vasc. Pl. Lao PDR: 71.

ESperlingia verticillata Vahl, 1810, Skrivt. Nat. Selsk. 6: 113.

Fig. 18B-F, 19.

Described supposedly from NE. India. Lectotype (Flohr in Hb. Vahl 'ex Ind. Orient. Cynanchum?') C [C10006735], designated by Veldkamp et al. (1995); possible isolectotype - C [C10006736]).

= Hoya balansae Costantin, 1912, Fl. Indo-Chine 4: 136; Pham H.H., 2003, Ill. Fl. Vietnam 2: 747, fig. 6988; Tran T.B., 2005, Checklist Pl. Sp. Vietnam 3: 66, syn. nov.

Described from northern Vietnam ("Ha Long bay, Quang Ninh province"). Lectotype ("Tonkin, baie d'Along, B. Balansa 598, 1885-7-3") - P [P00645997], designated by Rodda (2017).

Habitat, phenology and conservation status. Creeping epiphytic and lithophytic semi-woody vine to $12 \mathrm{~m}$ long. Primary and secondary broadleaved evergreen forests on limestone, commonly on vertical cliffs, on mossy mountain tops, and along stream canons, 5-900 m. Fl. March - May, flowers from almost white to yellowish or pink, odourless to very fragrant. Locally very common. Estimated IUCN Red List status - LC.

Distribution. Cambodia (Sihanoukville town, Kaoh Rong Samloem Khong Island), Laos (Bolikhamsai, Louangphrabang and Vientiane provinces), Vietnam (Hai Phong and Quang Ninh province). NE India, Bangladesh, Thailand.

Notes. The examination of the type specimens and of the new material of Hoya balansae reveals a close similarity with the $H$. verticillata (Vahl) G. Don (Vahl, 1810; Don, 1838) complex. Following the study of the complex carried out in Thailand by Kidyoo et al. $(2006,2007)$ the $H$. balansae can be identified as belonging to group "V" based on 
leaf shape and base and group "VI" or "VII" based on calyx lobe shape. Groups "V-IX" are considered as variable forms of $H$. verticillata var. verticillata; therefore, $H$. balansae is here considered as a new synonym of $H$. verticillata.

Studied specimens. Southern Cambodia, to the N of Sihanoukville town, Kaoh Rong Samloem Khong Island in Siam Gulf, low hills around point $10^{\circ} 36^{\prime} 45^{\prime \prime} \mathrm{N}, 103^{\circ} 18^{\prime} 38^{\prime \prime} \mathrm{E}$, dry evergreen lowland forest, 19 November 2011, T. Maisak, M. Telepova, L. Osinovetz, 843, flowered in cultivation in June 2014, flowers white, with very strong honey fragrance, corona in center purple (LE, LE photos). Central Laos, Vientiane province, Vang Vieng district, Khan Mac village, 1851'26.4”N, $102^{\circ} 28^{\prime} 36.7^{\prime \prime} \mathrm{E}$, secondary broad-leaved deciduous open dry forest on limestone at 400-500 m, long creeping semi-woody vine to $12 \mathrm{~m}$ long, locally very common, 23 March 2017, L. Averyanov et al., LA-VN 1567 (FOF, LE). Central Laos, Bolikhamsai province, Thaphabat district, Nam Bon village, Phou Khao Khouay national park, Tad Xai Waterfall, $18^{\circ} 27^{\prime} 25.9^{\prime \prime} \mathrm{N}, 103^{\circ} 08^{\prime} 17.5^{\prime \prime} \mathrm{E}$, degraded primary and secondary evergreen dry forest along river on eroded sandstone at $340 \mathrm{~m}$, semi-woody epiphytic and lithophytic vine 4-6 m long in rather open place, flowers almost odorless, white, common, 11 April 2017, L. Averyanov et al., LA-VN 2194 (FOF, LE). Northern Laos, Vientiane province, Kasi district, Si Sang Vone village, $19^{\circ} 06^{\prime} 10.9^{\prime \prime} \mathrm{N}$, $102^{\circ} 10^{\prime} 46.1$ 'E, secondary and primary evergreen dry forest on limestone at $600-750 \mathrm{~m}$,

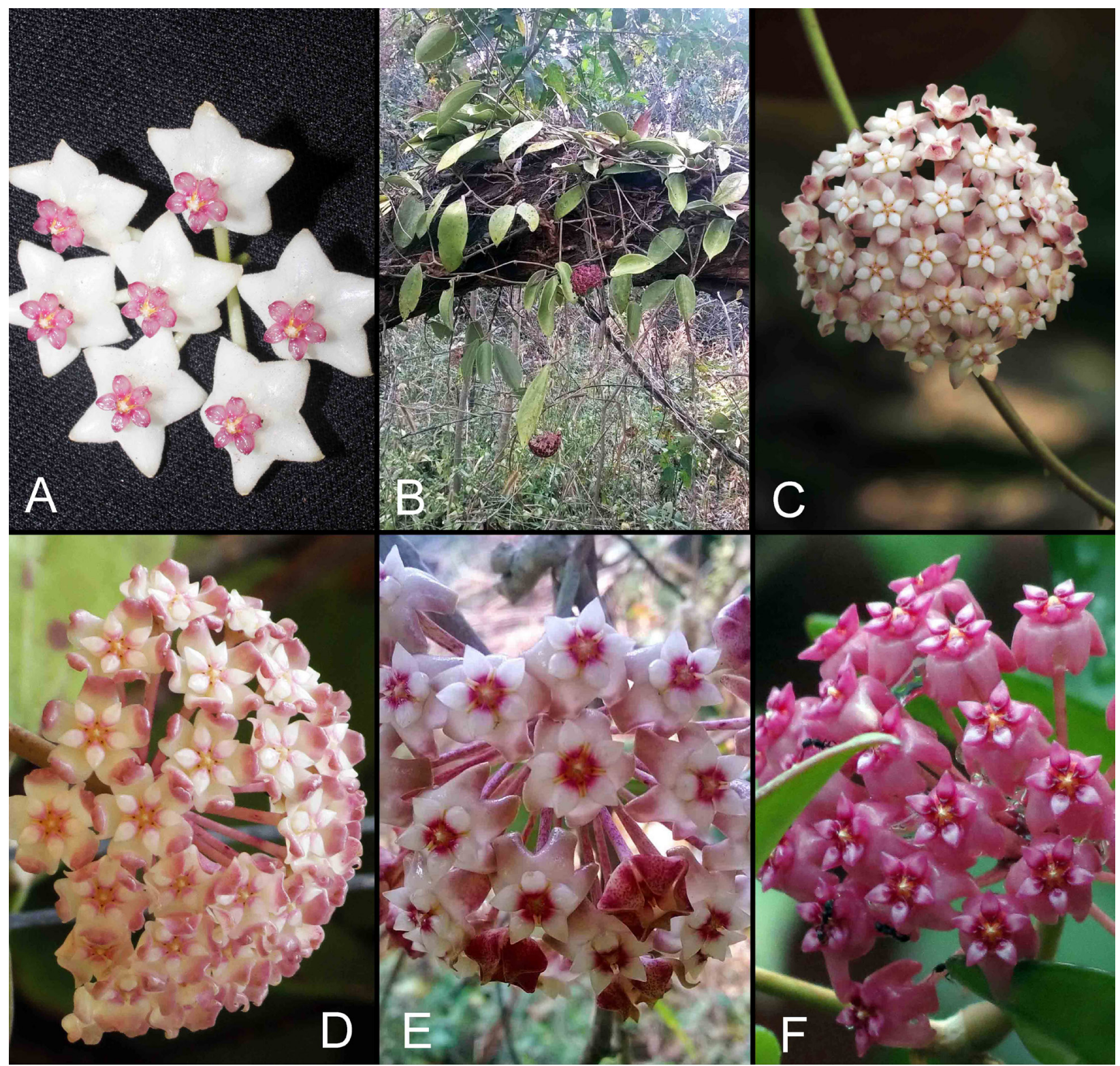

Fig. 18. Hoya vaccinioides Hook. f.: A (7 May 2016, N. P. Tam s. n., photos of N. P. Tam). H. verticillata (Vahl) G. Don: B-F (N. V. Canh s. n., 2014, AL 240). 


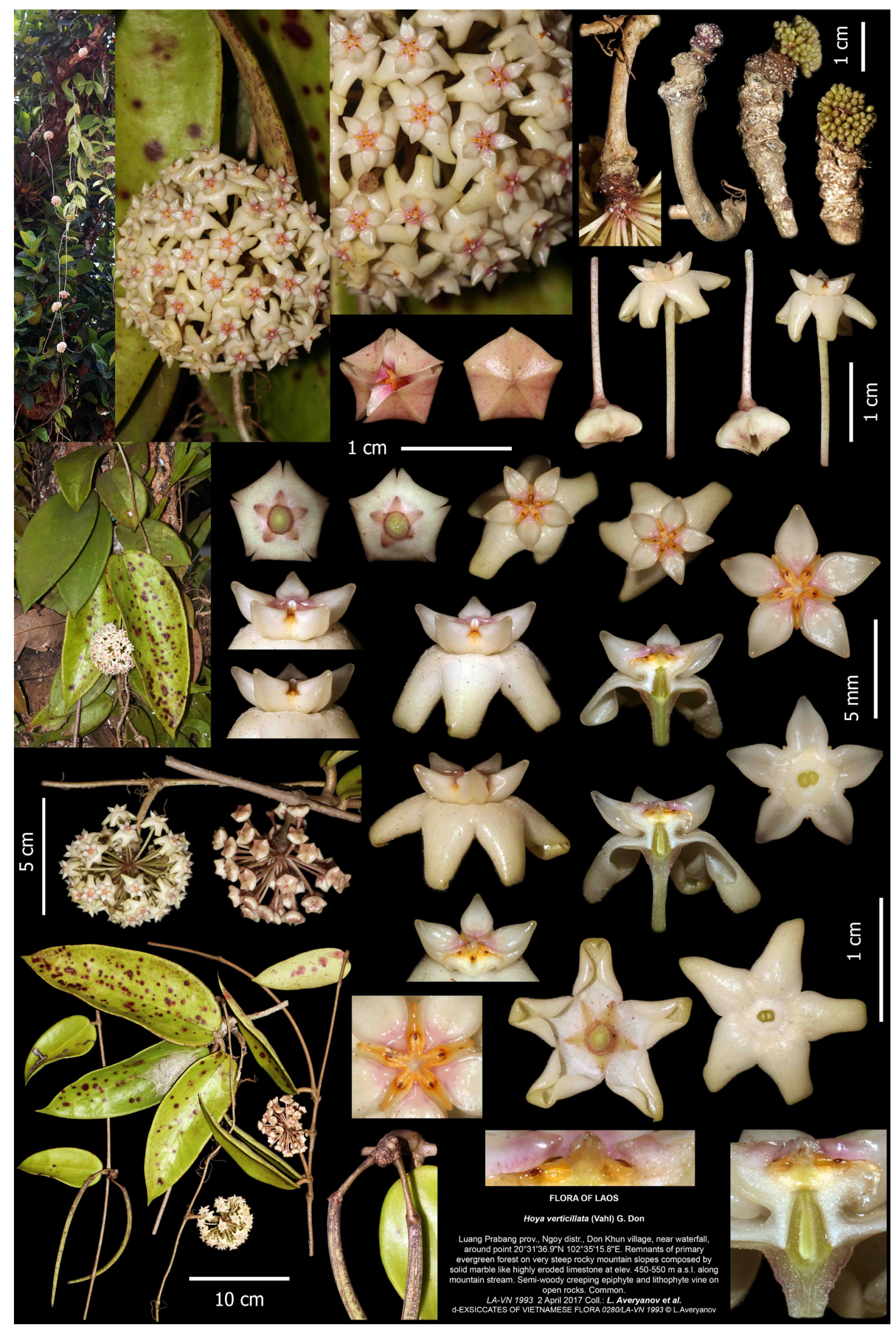

Fig. 19. Hoya verticillata (Vahl) G. Don. Digital Vietnamese flora 0280/LA-VN 1993. Photos, correction and design by L. Averyanov. 
creeping epiphytic and lithophytic semi-woody vine on rocky mountain top, not rare, 28 March 2017, L. Averyanov et al., LA-VN 1857 (FOF, LE). Northern Laos, Louangphrabang province, Ngoy district, Nong Khiew village, Ta Nang Non Mountain, $20^{\circ} 33^{\prime} 29.2^{\prime \prime} \mathrm{N}, 102^{\circ} 36^{\prime} 54.5^{\prime \prime} \mathrm{E}$, secondary semideciduous and evergreen dry forest on limestone at $600-650 \mathrm{~m}$, semi-woody vine on mossy rocky mountain top, common, 31 March 2017, L. Averyanov et al., LA-VN 1928 (FOF, LE). Northern Laos, Louangphrabang province, Ngoy district, Nong Khiew village, Ta Nang Non Mountain, $20^{\circ} 33^{\prime} 29.2^{\prime \prime} \mathrm{N}, 102^{\circ} 36^{\prime} 54.5^{\prime \prime} \mathrm{E}$, secondary semideciduous and evergreen dry forest on limestone at $600-650 \mathrm{~m}$, semi-woody vine on mossy rocky mountain top, locally common, 31 March 2017, L. Averyanov et al., LA-VN 1931 (FOF, LE). Northern Laos, Louangphrabang province, Ngoy district, Ngoy village, Pha Noi Mountain, $20^{\circ} 42^{\prime} 53.6^{\prime \prime} \mathrm{N}, 102^{\circ} 40^{\prime} 34.7^{\prime \prime} \mathrm{E}$, remnants of primary evergreen forest on limestone at $400-450 \mathrm{~m}$, epiphytic and lithophytic creeping semi-woody vine to 6-8 $\mathrm{m}$ long on mossy rocky mountain top, flowers white to light yellowish or pinkish, very fragrant, very common, 1 April 2017, L. Averyanov et al., LA-VN 1976 (FOF, LE). Northern Laos, Louangphrabang province, Ngoy district, Don Khun village, near waterfall, $20^{\circ} 31^{\prime} 36.9^{\prime \prime} \mathrm{N}, 102^{\circ} 35^{\prime} 15.8^{\prime \prime} \mathrm{E}$, remnants of primary evergreen forest on limestone at $450-550 \mathrm{~m}$, along mountain stream, semi-woody creeping epiphyte and lithophyte vine on open rocks, flowers white, light yellowish or pinkish, fragrant, common, 2 April 2017, L. Averyanov et al., LA-VN 1993: d-EXSICCATES OF VIETNAMESE FLORA 0280/LA-VN 1993, fig. 19 (FOF, LE); creeping epiphytic and lithophytic vine 3-4 m long in open place, flowers light pinkish, very common, 2 April 2017, L. Averyanov et al., LA-VN 2015 (FOF, LE). Northern Laos, Louangphrabang province, Pon Xay district, between Houay Man and Nam Bo villages, Phou Hua Ben Toc Mountain, 1957'33.1'N, $102^{\circ} 25^{\prime} 25.8^{\prime} \mathrm{E}$, degraded primary evergreen and semideciduous forest on limestone at 500-650 m, long creeping semi-woody vine 6-8 m long, flowers white to light yellowish, center of corona purple, locally very common, 5 April 2017, L. Averyanov et al., LA-VN 2115 (FOF, LE); long creeping semiwoody vine 6-8 $\mathrm{m}$ long, flowers white to light yellowish including corona, leaves with purple tint to dull pale dirty purple. locally common, 5 April 2017, L. Averyanov et al., LA-VN 2118 (FOF, LE). Northern Laos, Louangphrabang province, Pon Xay district, along the way to Bane Phou Souong village, Pha Hiua Bin Toc Mountain, 1957'37.0'N, $102^{\circ} 25^{\prime} 03.0^{\prime \prime} \mathrm{E}$, degraded primary evergreen and semideciduous forest on limestone at $600-850 \mathrm{~m}$, creeping semi-woody epiphytic and lithophytic vine on open rocky slope near mountain top, flowers white, corona white with purple center, not rare, 5 April 2017, L. Averyanov et al., LA-VN 2163 (FOF, LE). Northern Vietnam, Haiphong City area, 2014, N. V. Canh, cultivated in private garden in Buon Ma Thuot City, L. Averyanov AL 240, photos of N. V. Canh (LE - photos). Northern Vietnam, Quang Ninh province, Hon Gai district, Ha Long Bay, Dau Go Island, $20^{\circ} 54^{\prime} \mathrm{N}, 107^{\circ} 01^{\prime} \mathrm{E}$, secondary broadleaved evergreen forest on steep limestone slopes and vertical bluffs, at $0-100 \mathrm{~m}$, lithophytic vine 3-4 $\mathrm{m}$ long on open rocks, flowers yellowish, often with purple tint, locally very common, 12 May 1999, $N$. T. Hiep, L. Averyanov, NTH 2620 (HN). Northern Vietnam, Quang Ninh province, Ha Long Bay, Doi Vai Island, vine on rock, white latex, flowers white, very common in Ha Long bay, 12 April 2000, N. T. Hiep NTH 4218 (HN). Northern Vietnam, Quang Ninh province, Ha Long Bay, Trinh $\mathrm{Nu}$ Cave, $20^{\circ} 50^{\prime} \mathrm{N}, 107^{\circ} 06^{\prime} \mathrm{E}$, secondary limestone forest at elevations $0-100 \mathrm{~m}$, epiphyte and lithophyte, white flowers, fragrant, common, 6 July 2003, N. X. Tam, P. V. The, NTH 5712 (HN). Northern Vietnam, Quang Ninh province, Ha Long Bay, Me Cung Cave, $20^{\circ} 50^{\prime} 14^{\prime \prime} \mathrm{N}, 107^{\circ} 04^{\prime} 26^{\prime \prime} \mathrm{E}$, secondary limestone forest at 0-100 m, epiphyte with white latex, flowers pinkish, at base of mountain, locally common, 28 February 2003, N. X. Tam, P. V. The, NTH $5600(\mathrm{HN})$.

Acknowledgements. Field works, results of which are presented in this paper were financially supported in part by USA National Geographic Society, "Assessment of plant diversity in main limestone areas of central Laos" (\#9906-16) and Russian Foundation for Basic Research "Plant taxonomy, geography and biology in local floras of eastern Indochina" (15-04-00419A), and were carried out in the framework of institutional research project of the Komarov Botanical Institute of the Russian Academy of Sciences. We are grateful to following persons for various support such as the organizing of field explorations, photography, specimen collecting, field data and kind assistance during fieldworks - Phan Ke Loc, Nguyen Tien Vinh, Nguyen Xuan Dang, Chu Xuan Canh, Ben Rawson, Kirrily Apthorp, Nguyen Dinh Hai, Nguyen Mau Toan, Dao The Anh, Pham Doan Quoc Vuong, Ngo Thi Diem My, Lam Thi Ngoc Thanh, and Vu Truong Nhat. 


\section{REFERENCES}

Blume C. L. 1823. Catalogus van eenige der Merkwaardigste Zoo in-als Uitheemse Gewassen te Vinden in 's Lands Plantentuin te Buitenzorg. Tuin s. 1. n. d., Batavia, 113 pp.

Blume C. L. 1826. Bijdragen tot de flora van Nederlandsch Indië 16. Ter Lands Drukkerij, Batavia, 1169 pp. DOI: 10.5962/bhl.title.395.

Boerlage J. G. 1899. Handleiding tot de kennis der flora van Nederlandsch Indië E. J. Brill, Leiden, 2, 2: $323-753$. URL: http://biodiversitylibrary.org/page/5868744.

Brown R. 1810. Prodromus florae Novae Hollandiae et insulae Van Diemen, etc. Richard Taylor, London, 984 pp. DOI: $10.5962 /$ bhl.title.3633.

Burton C. M. 1996. A Tantative Alternative Arrangement of Hoya Sections. Hoyan 18: 2-6.

Costantin J. 1912. Hoya. In: Flore générale de l'Indo-Chine 4. Ed. M. H. Lecomte. Masson et Cie, Paris, $125-141$ pp. DOI: biodiversitylibrary.org/item/97510\#page/139/mode/1up.

Dalzell N. A. 1852. Contributions to the botany of Western India. Hooker's Journ Bot. Kew Gard. Misc. 4: 289 295. DOI: biodiversitylibrary.org/item/6322\#page/304/mode/1up.

Decaisne J. 1844. Ordo CXXX Asclepiadeae. In: Prodromus Syst. Nat. Regni Vegetabilis 8. Ed. A. P. de Candolle. Sumptibus Sociorum Treuttel et Würtz, Paris, 490-665 pp. URL: http://dx.doi.org/10.5962/bhl.title.286.

Don D. 1825. Prodromus florae Nepalensis. J. Gale, London, 256 pp. DOI: biodiversitylibrary.org/ item/1820\#page/266/mode/1up.

Don G. 1838. A general history of the dichlamydeous plants. J. G. and F. Rivington, London, 908 pp. DOI: 10.5962/bhl.title.502.

Forster P. I., Liddle D. J. 1996. Hoya. In: Flora of Australia 28. Ed. H. Hewson. CSIRO, Dickson, 231-237 pp.

Forster P. I. 2006. The asclepiad flora of New Guinea. In: The ecology of Papua. Eds A. J. Marshall, B. M. Beehler. Periplus Editions, 371-378 pp.

Gilbert M. G., Stevens W. D., Li P. T. 1995. Notes on the Asclepiadaceae of China. Novon 5: 1-16.

Green T. 1994. Hoya loyceandrewsiana Green. Fraterna 21, 2: 22; id., 1994, Fraterna 4: 4, nom. Invalid: 3-5.

Haworth A. H. 1821. Saxifragëarum enumeration 2. R. et A. Taylor, London, 207 pp. DOI: 10.5962/bhl.title.9670.

Hooker J. D. 1882. Hoya globulosa, Hk. f. ined. Gard Chronicle n. s. 17: 732, 741, fig. 115. DOI: biodiversitylibrary.org/page/25598809.

Hooker J. D. 1883. The Flora of British India, 4. L. URL: http://www.biodiversitylibrary.org/item/13817\#page/2/ mode/lup.

Hooker W. J. 1848. Hoya bella. Botanical Magazine. Ser. 3, 4, tab. 4402.

Hosseus C. C. 1907. III Zwei interessante Neuheiten aus Siam Kgl. Bot. Garten zu Dahlem. Notizbl. Königl. Bot. Gart. Berlin. 4: 314-318.

The IUCN Red List of Threatened Species. 2016. Version 2016.1. URL: http:/www.iucnredlist.org/technical-documents/categories-and-criteria. [Accessed: 22 January 2017].

Jagtap A. P., Singh N. P. 1999. Hoya. In: Fascicles of Flora of India. Fascicle 24. Eds A. P. Jagtap, N. P. Singh. Botanical Survey of India, Calcutta, 91-122 pp.

Kent D. H. 1981. Notes on Hoya in cultivation, 1. Asklepios 23: 24-28.

$\operatorname{Kerr}$ A. F. G. 1939. Contribution to the flora of Siam. Add. 52. Bulletin Misc. Inform. Kew. 8: 456-465.

Kerr A. F. G. 1951. Hoya R. Br. In: Florae Siamensis Enumeratio. Ed. R. L. Pendleton. Siam Society, Bangkok, 3, 1: 35-42.

Kidyoo M., Thaithong O. 2007a. A new record of Hoya (Asclepiadaceae) from Northern Thailand. The Natural History Journal of Chulalongkorn University 7, 1: 47-50.

Kidyoo M., Thaithong O. 2 007b. A new species of Hoya (Asclepiadaceae) from southern Thailand. Blumea 52: 327-330. DOI: 10.3767/000651907X609052.

Kidyoo M., Boonkerd T., Seelanan, T., Thaithong O. 2007. Variations in the Hoya verticillata complex in Thailand. Gard. Bull. Singapore 58: 179-198.

Kidyoo M., Thaweesakdi B., Obchant, T., Tosak S. 2006. Variation within the Hoya parasitica (Asclepiadaceae) Complex in Thailand. BTR Research Reports. No pagination. URL: http://wwwla.biotec.or.th/brt/index.php/ download/doc download/103-17.

Kloppenburg R. D. 2005. The cover story is a new species, Hoya weebella Kloppenburg, from Northern Thailand. Fraterna 18, 2: 1-7.

Kress J., De Filippis R. A., Farr E., Daw Yin Yin Kyi. 2003. A Checklist of the Trees, Shrubs, Herbs, and Climbers of Myanmar. Contributions from the United States National Herbarium 45: 155-156.

Leveille J.-H. 1907. Nouvelles especes de la Chine. Bull. Soc. Bot. France 54: 368-371. DOI: biodiversitylibrary. org/page/325948.

Li P. T. 1994. Three new species of Hoya (Asclepiadaceae) from Myanmar. Journ. S. China Agric. Univ. 15, 2: 73-76. 
Li P. T., Gilbert M. G., Stevens W. D. 1995. Asclepiadaceae. In: Flora of China. Ed. Z. Y. Wu, P. H. Raven. Sci. Press, Beijing \& Missouri Bot. Garden Press, St. Louis, 16: 228-236.

Liddle D. J. 2009. Tropical Hoyas. Subtrop. Gard. 16: 26-31.

Linne C. 1782. Supplementum plantarum. Impensis Orphanotrophei, Brunsvigae, 468 pp. DOI: 10.5962/bhl. title.555.

Loureiro J. 1790. Flora cochinchinensis. Typis et expensis academicis, Ulyssipone, 744 pp. DOI: 10.5962/bhl. title.560.

Merrill E. D. 1923. Diagnoses of Hainan plants II. Philipp. Journ. Sci. 23: 237-268.

Merrill E. D. 1934. A Fifth Supplementary List of Hainan Plants. Lingnan Science Journal 13: 53-74.

Moon A. 1824. Catalogue of the indigenous and exotic Plants growing in Ceylon. Printed at the Wesleyan Mission Press, Colombo, 196 pp. URL: http://archive.org/details/acatalogueindig00moongoog.

Newman M., Ketphanh S., Svengsuksa B., Thomas P., Sengdala K., Lamxay V., Armstrong K. 2007. A Checklist of the vascular plants of Lao PDR. Royal Botanic Garden, Edinburgh, 394 pp. URL: http://portals.iucn.org/library/ efiles/documents/2007-014.pdf.

Noltie H. J. 2005. The Botany of Robert Wight. Regnum Vegetabile 145. A. R. G. Gantner, Ruggell, 579 pp.

Pham H. H. 2003. An illustrated flora of Vietnam, 2. Tre Publ. House, Hanoi, 951 pp.

Pham V. T., Averyanov L. V. 2012. Hoya longipedunculata sp. nov. (Apocynaceae, Asclepiadoideae) from Quang Nam, central Vietnam. Nord. Journ. Bot. 30: 705-708. DOI: 10.1111/j.1756-1051.2012.01588.

Pham V. T., Tuan A. L., Averyanov L. V. 2015. Hoya hanhiae sp. nov. (Apocynaceae, Asclepiadoideae) from central Vietnam. Nord. Journ. Bot. 33: 64-67. DOI: 10.1111/njb.00541.

Rintz R. E. 1978. The Peninsular Malaysian species of Hoya (Asclepiadaceae). Malayan Nat. Journ. 30, 3-4: 467-522.

Rodda M. 2012. Taxonomy of Hoya lyi, Hoya yuennanensis and Hoya mekongensis (Apocynaceae - Asclepiadoideae). Edinburgh Journ. Botany 69: 83-93. DOI: 10.1017/S0960428611000412.

Rodda M. 2015. Two new species of Hoya R. Br. (Apocynaceae, Asclepiadoideae) from Borneo. PhytoKeys 53: 83-93.

Rodda M. 2016. (2485) Proposal to reject the name Stapelia cochinchinensis (Hoya cochinchinensis) (Apocynaceae). Taxon 65(6): 1430-1430.

Rodda M. 2017. Index of names and types of Hoya (Apocynaceae: Asclepiadoideae) of Borneo. Gard. Bull. Singapore 69: 33-65.

Rodda M., Simonsson Juhonewe N. 2012a. Taxonomic notes on the long-lost Hoya burmanica (Apocynaceae, Asclepiadoideae) from Myanmar. Kew Bulletin 67: 1-6. DOI: 10.1007/s12225-012-9377-1.

Rodda M., Simonsson Juhonewe N. 2012b. Hoya mappigera (Apocynaceae, Asclepiadoideae), a new campanulate flowered species from Peninsular Malaysia and southern Thailand. Feddes Repert. 122: 337-343. URL: http:// dx.doi.org/10.1002/fedr.201100019.

Rodda M., Simonsson Juhonewe N. 2013. The taxonomy of Hoya micrantha and Hoya revoluta (Apocynaceae, Asclepiadoideae). Webbia 68, 1: 7-16. DOI: 10.1080/00837792.2013.802937.

Rodda M., Tran T. B., Simonsson Juhonewe N., Ly N. S. 2012. Hoya thuathienhuensis and Hoya graveolens (Apocynaceae, Asclepiadoideae), a new species and a new record for the flora of Vietnam. New sp. Hoya Vietnam, 10 pp.

Rodda M., Tran T. B., Simonsson Juhonewe N., Ly N. S. 2013. Hoya thuathienhuensis and Hoya graveolens (Apocynaceae, Asclepiadoideae), a new species and a new record for the flora of Vietnam. Blumea 57: 243-247. DOI: 10.3767/000651913X663992.

Rodda M., Simonsson Juhonewe N., Sri R. 2014. Taxonomic revision of the Hoya mindorensis complex (Apocynaceae-Asclepiadoideae). Webbia 69: 39-47. DOI: 10.1080/00837792.2014.900261.

Rodda M., Tran T. B., Quoc B. N. 2015. Hoya tamdaoensis (Apocynaceae, Asclepiadoideae), a new species from Vietnam. Phytotaxa 217, 3: 288-292. DOI: 10.11646/phytotaxa.217.3.6.

Rodda M., Simonsson Juhonewe N., Middleton D. J. 2016. The taxonomic status of the presumed extinct Singaporean Hoya wallichii (Apocynaceae: Asclepiadoideae). Gard. Bull. Singapore 68: 175-187.

Rolfe R. A. 1920. Hoya burmanica Rolfe (Asclepiadeae - Marsdenieae) in Decades Kewenses C CI. Bull. Misc. Inform. Kew. 335-344 pp. DOI: biodiversitylibrary.org/item/42874\#page/2/mode/1up.

Schultes J. A. 1820. Hoya. In: Systema vegetabilium ed. 15 bis 6. Eds J. J. Roemer, J. A. Schultes. Sumtibus J. G. Cottae, Stuttgardt, 50-52 pp. URL: http://biodiversitylibrary.org/page/731808.

Sims J. 1804. Asclepias carnosa. Thick-Leaved Asclepias. Bot. Mag. 21, tab. 788. DOI: biodiversitylibrary.org/ page/471723.

Thaithong O. 2001. A new species of Hoya (Asclepiadaceae) from Thailand. Nord. Journ. Bot. 21: 143-145. DOI: 10.3767/000651907X609052.

The P. V., Averyanov L. V. 2012. New species from Vietnam - Hoya lockii (Apocynaceae, Asclepiadoideae). Taiwania 57: 49-54. DOI: tai2.ntu.edu.tw/taiwania/pdf/tai.2012.57.49.pdf. 
Tran T. B. 2005. Hoya. In: Checklist of plant species of Vietnam, 3. Ed. N. T. Ban. Agriculture Publishing House, Hanoi, 66-68 pp.

Tran T. B., Joo-Hwan K., Dong-Kap K. J., Joongku L., Bui T. H., Simonsson Juhonewe N., Rodda M. 2011 a. Hoya ignorata (Apocynaceae, Asclepiadoideae): An overlooked species widely distributed across South East Asia. Novon 21: 508-514. DOI: 10.3417/2010068.

Tran T. B., Rodda M., Joo-Hwan K., Joongku L., Dong-Kap K., Bui T. H. 2011b. Hoya sapaensis (Apocynaceae, Asclepiadoideae), a new species from Vietnam. Ann. Bot. Fenn. 48: 511-514. DOI: 10.5735/085.048.0612.

Tsiang Y., Li P. T. 1974. Praecursores florae Asclepiadacearum Sinensium. Acta Phytotax. Sin. 12, 1: 79-149.

Vahl M. H. 1810. Bestrivelse over nye Plantlstgter. Skrifter af Naturhistorie-Selskabet 6: 84-128. DOI: books. google.ru/books?vid=HARVARD:32044106425143\&printsec=titlepage\&redir_esc=y\#v=onepage\&q\&f=false.

Veldkamp J. F., van Donkelaar R., Kloppenburg R. D. 1995. The identity of Sperlingia Vahl (Asclepiadaceae). Blumea 40: 425-428.

Wight R. 1834. Contributions to the botany of India. Parbury, Allen \& Co, London, 147 pp. DOI: archive.org/ stream/contributionsto00wighgoog\#page/n43/mode/1up/search/37. 